\title{
Lactic Acid Bacteria in Finfish-An Update
}

\author{
Einar Ringø ${ }^{1 *}$, Seyed Hossein Hoseinifar ${ }^{2}$, Koushik Ghosh ${ }^{3}$, Hien Van Doan ${ }^{4}$, \\ Bo Ram Beck ${ }^{5 t}$ and Seong Kyu Song ${ }^{5}$
}

${ }^{1}$ Faculty of Bioscience, Fisheries and Economics, Norwegian College of Fishery Science, UiT The Arctic University of Norway, Tromsø, Norway, ${ }^{2}$ Department of Fisheries, Faculty of Fisheries and Environmental Sciences, Gorgan University of Agricultural Sciences and Natural Resources, Gorgan, Iran, ${ }^{3}$ Aquaculture Laboratory, Department of Zoology, The University of Burdwan, Bardhaman, India, ${ }^{4}$ Department of Animal and Aquatic Sciences, Faculty of Agriculture, Chiang Mai University, Chiang Mai, Thailand, ${ }^{5}$ School of Life Science, Handong University, Pohang, South Korea

A complex and dynamic community of microorganisms, play important roles within the fish gastrointestinal (Gl) tract. Of the bacteria colonizing the Gl tract, are lactic acid bacteria ( $L A B)$ generally considered as favorable microorganism due to their abilities to stimulating host Gl development, digestive function, mucosal tolerance, stimulating immune response, and improved disease resistance. In early finfish studies, were culture-dependent methods used to enumerate bacterial population levels within the Gl tract. However, due to limitations by using culture methods, culture-independent techniques have been used during the last decade. These investigations have revealed the presence of Lactobacillus, Lactococcus, Leuconostoc, Enterococcus, Streptococcus, Carnobacterium, Weissella, and Pediococcus as indigenous species. Numerous strains of $L A B$ isolated from finfish are able to produce antibacterial substances toward different potential fish pathogenic bacteria as well as human pathogens. $\angle A B$ are revealed be the most promising bacterial genera as probiotic in aquaculture. During the decade numerous investigations are performed on evaluation of probiotic properties of different genus and species of LAB. Except limited contradictory reports, most of administered strains displayed beneficial effects on both, growth - and reproductive performance, immune responses and disease resistance of finfish. This eventually led to industrial scale up and introduction $L A B$-based commercial probiotics. Pathogenic LAB belonging to the genera Streptococcus, Enterococcus, Lactobacillus, Carnobacterium, and Lactococcus have been detected from ascites, kidney, liver, heart, and spleen of several finfish species. These pathogenic bacteria will be addressed in present review which includes their impacts on finfish aquaculture, possible routes for treatment. Finfish share many common structures and functions of the immune system with warm-blooded animals, although apparent differences exist. This similarity in the immune system may result in many shared $L A B$ effects between finfish and land animals. $L A B$-fed fish show an increase in innate immune activities leading to disease resistances: neutrophil activity, lysozyme secretion, phagocytosis, and production of pro-inflammatory cytokines $(I L-1 \beta, I L-6, I L-8$, and $T N F-\alpha)$. However, some LAB strains preferentially induces $I L-10$ instead, a potent anti-inflammatory cytokine. These results indicate that $L A B$ may vary in their immunological effects depending on the species and hosts. 
So far, the immunological studies using $L A B$ have been focused on their effects on innate immunity. However, these studies need to be further extended by investigating their involvement in the modulation of adaptive immunity. The present review paper focuses on recent findings in the field of isolation and detection of $L A B$, their administration as probiotic in aquaculture and their interaction with fish immune responses. Furthermore, the mode of action of probiotics on finfish are discussed.

Keywords: lactic acid bacteria (LAB), finfish, probiotics, probiotic bacteria, fish immunity, aquaculture

\section{INTRODUCTION}

Optimal gastrointestinal (GI) functionality is essential for sustainable animal production. Effective functionality of the finfish GI tract and its gut microbiota play and important role in host health (Ringø et al., 2003; Round and Mazmanian, 2009), and several complex mechanisms are involved, and in the absence of gut microbiota, normal immune development, and function are impaired. Therefore it is crucial to increase our knowledge on beneficial gut bacteria, for example lactic acid bacteria (LAB) colonizing the GI tract, in the context of improved growth performance and health.

LAB are classified in phylum Firmicutes, class Bacilli, and order Latobacillales. They are Gram-positive, non-endosporing, with rod-shaped or coccid morphology, are catalase- and oxidase-negative and most of them are non-motile. The growth optimum of LAB is generally at $\mathrm{pH} 5.5-5.8$, and they have complex nutritional requirements. They are divided into homofermentative and heterofermentative; homofermentative produce lactic acid from sugars, while heterofermentative produce lactic acid, acetic acid or alcohol, and carbon dioxide. A favorable trait of $\mathrm{LAB}$ is; they produce growth inhibition substances such as bacteriocins, hydrogen peroxide, diacyls, etc.; prevent proliferation of pathogenic-and spoilage bacteria in food (Alakomi et al., 2000; De Vuyst and Leroy, 2007), as well as adherence and colonization of pathogens in the digestive tract (Li et al., 2018).

LAB genera include rods; Carnobacterium, Dolosigranulum, and Lactobacillus, cocci; Aerococcus, Alloiococcus, Enterococcus, Lactococcus, Leuconostoc, Oenococcus, Pediococcus, Streptococcus, Tetragenococcus, and Vagococcus, and the coccoid or rod-shaped genus Weissella (Walter, 2008; Ventura et al., 2009; Fusco et al., 2015). They are isolated from different sources; e.g., plant material, fruits, dairy products, fermented meat, cavities of humans as well as the gastrointestinal (GI) tract of finfish (e.g., Ventura et al., 2009; Merrifield et al., 2014; Ringø et al., 2016).

The fish gut microbiota plays an important role in GI tract development, digestive function, mucosal tolerance, stimulating the host immune response, and protection against infections (e.g., Rawls et al., 2004, 2006; Gómez and Balcázar, 2008; German, 2009; Ray et al., 2012; Maiuta et al., 2013; Piazzon et al., 2017; Tarnecki et al., 2017; Li et al., 2018; Wang et al., 2018). Furthermore, host-microbe interactions are influenced by complex host genetics and environment. In a recent review, Lescak and Milligan (2017) suggested teleost as model organisms to understand host-microbe interactions, as traditional mammalian studies can be limited by isogenic strains, small sample sizes, limited statistical power and indirect characterization of gut microbiota from fecal samples.

As the GI tract in fish is one of the most important interfaces with the environment exposed to potential pathogens, it is of importance to evaluate the presence of beneficial bacteria such as LAB in the GI tract, as autochthonous bacteria rapidly colonize the digestive tract at early developmental larval stages of finfish (Ringø et al., 1996).

During the last 20 years, an impressive amount of knowledge has been published on LAB in finfish intestine, their potential as probiotics, pathogenicity and their effect on the immune system (Ringø and Gatesoupe, 1998; Ringø, 2004; Ringø et al., 2005, 2012a,b; Gatesoupe, 2008; Lauzon and Ringø, 2011; Merrifield et al., 2014; Ringø and Song, 2016; Zhou Z. et al., 2018). To avoid duplication, studies reviewed in the aforementioned reviews are not addressed in the present paper. The current review aimed to present an updated overview of recently published data on LAB, and on $\mathrm{LAB}$ data not mention in the aforementioned reviews on the topics; on LAB in the GI tract of finfish, antagonistic ability, health benefits as probiotics, pathogenicity, and on immunostimulation.

\section{LACTIC ACID BACTERIA (LAB) IN THE GASTROINTESTINAL (GI) TRACT}

The GI tract microbiota in endothermic animals as well as fish is divided into; the GI lumen microbiota (the allochthonous), and those that adhere to the mucosal surface (the autochthonous microbiota). In most studied showed in Table 1 have, however, characterized the allochthonous gut microbiota.

During the last decades, numerous investigations on the isolations of LAB in finfish have been carried out. According to Merrifield et al. (2014) members belonging to Lactobacillus, Lactococcus, Leuconostoc, Enterococcus, Streptococcus, Carnobacterium, Pediococcus, and Weissella genera are indigenous species in finfish. In this subsection, results of some investigations published the last 3 years are presented. Readers with special interest in studies not described in the text are recommended to have a closer look at the original papers.

\section{LAB}

In numerous studies, counts of presumptive LAB has been revealed, but without going into further identification. In their 
TABLE 1 | Lactic acid bacteria $(\angle A B)$ in the gastrointestinal tract of finfish.

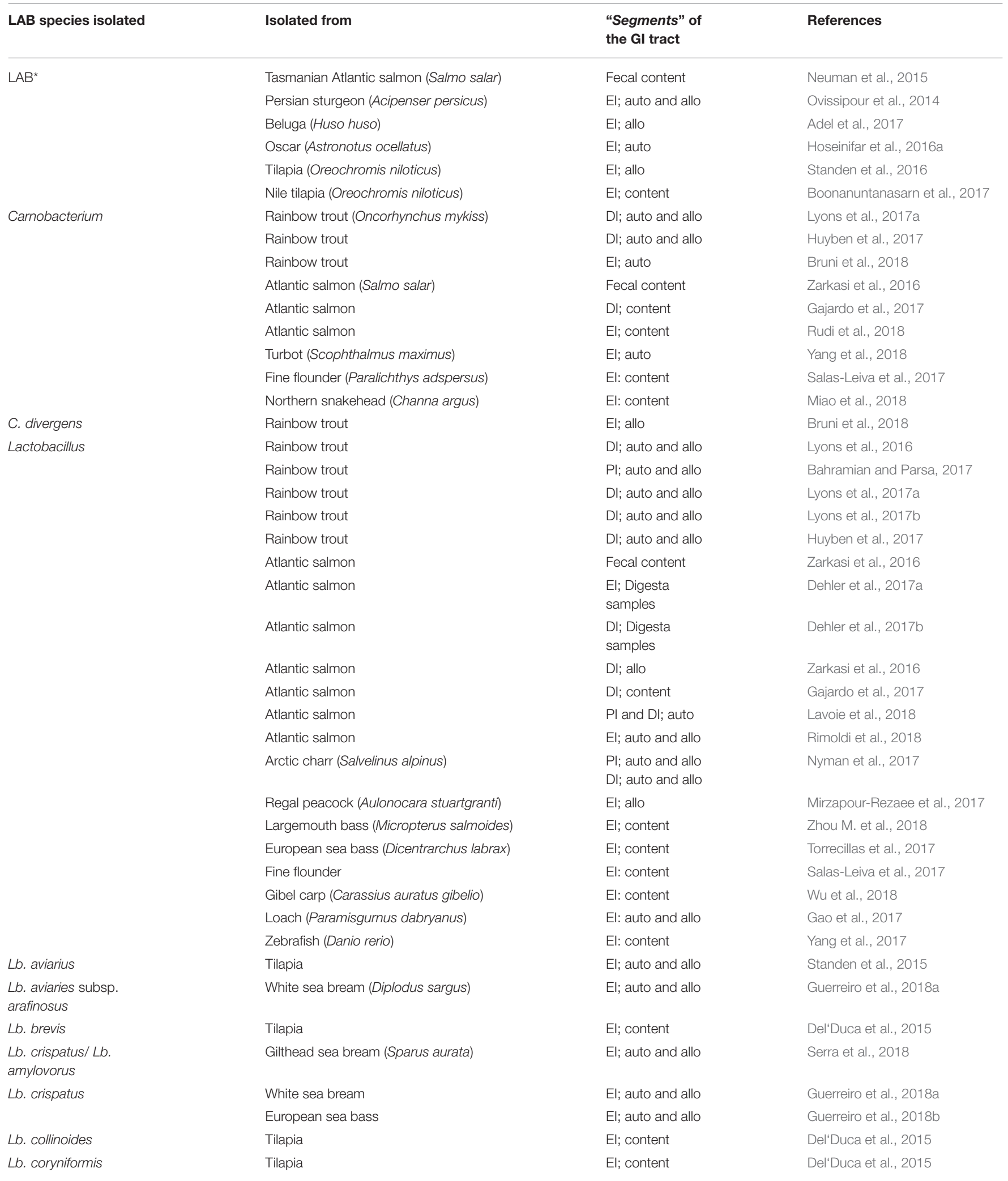


TABLE 1 | Continued

\begin{tabular}{|c|c|c|c|}
\hline LAB species isolated & Isolated from & $\begin{array}{l}\text { "Segments" of } \\
\text { the GI tract }\end{array}$ & References \\
\hline Lb. farciminis & Tilapia & El; content & Del‘Duca et al., 2015 \\
\hline Lb. johnsonii & European sea bass & El; content & Torrecillas et al., 2017 \\
\hline $\begin{array}{l}\text { Lb. paracasei subsp. } \\
\text { paracasei }\end{array}$ & Rainbow trout & El; content & Popovic et al., 2017 \\
\hline Lb. sakei & Rainbow trout & Dl: auto and allo & Didinen et al., 2018 \\
\hline \multirow[t]{12}{*}{ Lactococcus } & Rainbow trout & Dl; auto and allo & Lyons et al., 2016 \\
\hline & Rainbow trout & Dl; auto and allo & Lyons et al., 2017a \\
\hline & Rainbow trout & Dl; auto and allo & Lyons et al., 2017b \\
\hline & Rainbow trout & Dl; auto and allo & Huyben et al., 2017 \\
\hline & Atlantic salmon & El; auto and allo & Rimoldi et al., 2018 \\
\hline & Arctic charr & $\begin{array}{l}\text { Pl; auto and allo } \\
\text { Dl; auto and allo }\end{array}$ & Nyman et al., 2017 \\
\hline & Grass carp (Ctenopharyngodon idella) & $\mathrm{NI}$ & Tran et al., 2017 \\
\hline & Gibel carp & El: content & Wu et al., 2018 \\
\hline & Northern snakehead & El: content & Miao et al., 2018 \\
\hline & Loach & El: auto and allo & Gao et al., 2017 \\
\hline & Zebrafish & El: content & Yang et al., 2017 \\
\hline & Zebrafish & El: content & Zhou L. et al., 2018 \\
\hline L. garvieae & Pirarucu (Arapaima gigas) & El; auto and allo & do Vale Pereira et al., 2017 \\
\hline \multirow[t]{2}{*}{ L. raffinolactis } & Grass carp & El; auto & Li et al., 2015 \\
\hline & Grass carp & El; auto and allo & Dong et al., 2017 \\
\hline Leuconostocaceae & Rainbow trout & El; auto and allo & Huyben et al., 2018 \\
\hline \multirow[t]{9}{*}{ Leuconostoc } & Rainbow trout & Dl; auto and allo & Lyons et al., 2016 \\
\hline & Rainbow trout & Dl; auto and allo & Lyons et al., 2017b \\
\hline & Rainbow trout & Dl; auto and allo & Huyben et al., 2017 \\
\hline & Atlantic salmon & Digesta samples & Dehler et al., 2017b \\
\hline & Atlantic salmon & Dl; content & Gajardo et al., 2017 \\
\hline & Atlantic salmon & El; auto and allo & Rimoldi et al., 2018 \\
\hline & Arctic charr & $\begin{array}{l}\mathrm{Pl} \text {; auto and allo } \\
\text { DI; auto and allo }\end{array}$ & Nyman et al., 2017 \\
\hline & Tilapia & El; auto and allo & Standen et al., 2015 \\
\hline & Loach & El: auto and allo & Gao et al., 2017 \\
\hline \multirow[t]{3}{*}{ Pediococcus } & Atlantic salmon & Dl; content & Gajardo et al., 2017 \\
\hline & Atlantic salmon & $\mathrm{Pl}$ and DI; auto & Lavoie et al., 2018 \\
\hline & Turbot & El; auto & Yang et al., 2018 \\
\hline P. acidilactici & Rainbow trout & DI: allo & Didinen et al., 2018 \\
\hline \multirow[t]{2}{*}{ Streptococcacceae } & Rainbow trout & El; auto and allo & Huyben et al., 2018 \\
\hline & Atlantic salmon & PI and DI; auto & Lavoie et al., 2018 \\
\hline
\end{tabular}


TABLE 1 | Continued

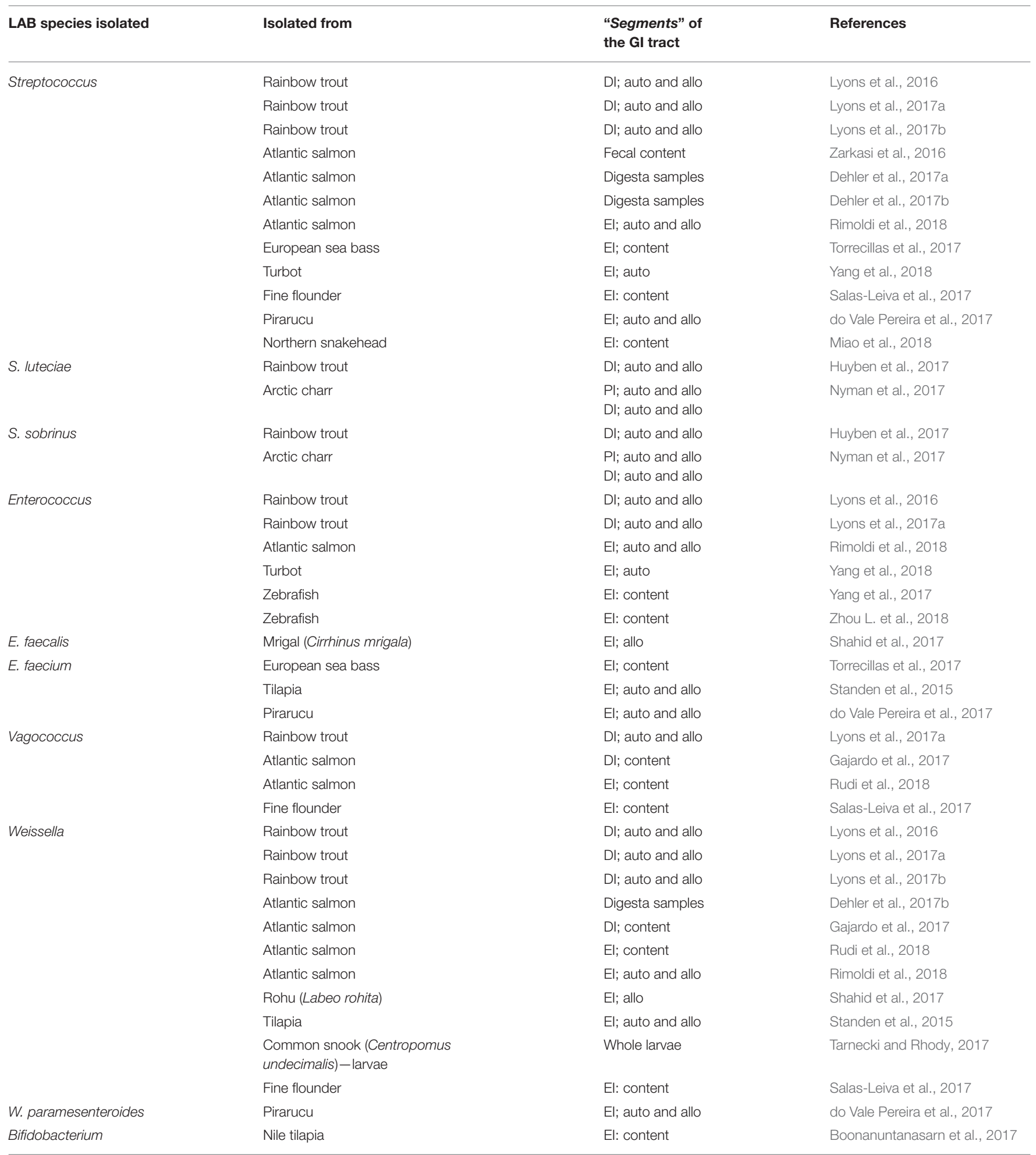

"A no further information was given; El, entire intestine without pyloric caeca; PI, posterior intestine; DI, distal intestine; auto, autochthonous; allo, allochthonous; NI, no information.

study of Persian sturgeon (Acipenser persicus L.) larvae fed tuna viscera protein hydrolysate, Ovissipour et al. (2014) reported that culturable LAB counts in the intestinal contents was significantly
$(P<0.05)$ higher when the larvae were fed fish protein hydrolysate at the highest inclusion level, $347 \mathrm{~g} \mathrm{~kg}^{-1}$, compared to control fed larvae. However, the log LAB counts were only 
$\sim 3.0$ compared to log levels of total counts; $\sim 5.0$. In their comprehensive review devoted to dietary effect on gut microbiota of finfish, Ringø et al. (2016) revealed an overview on gut microbiota due to seasonal variations. It is also worth mentioning that seasonal variations of Lactobacillus and putative pathogenic bacteria density occurs in aquaculture system (Resende et al., 2015). Neuman et al. (2015) evaluated the effect of diets, smolt-, summer, and growing diets, on fecal microbiota of farmed Tasmanian Atlantic salmon (Salmo salar L.) and revealed a decrease in LAB numbers during rearing from November to May. Furthermore, Hoseinifar et al. (2016a) revealed that increasing supplementation of xylooligosaccharide significantly increased population level of presumptive gut LAB in Oscar (Astronotus ocellatus).

\section{Carnobacterium}

Genus Carnobacterium belongs to the family Carnobacteriaceae within the order of Latobacillales and consists currently of 10 species of which; Carnobacterium (piscicola) maltaromaticum, C. mobile, Carnobacterium divergens, C. alterfunitum, and $C$. inhibens have been isolated from finfish intestine. The first study to isolate carnobacteria from GI tract of finfish, wild Atlantic salmon (S. salar L.), was carried out by Strøm (1988). She initially identified the bacterium as Lactobacillus plantarum Lab01, but later Ringø et al. (2001), reclassified the bacterium as C. divergens.

During the last 3 years, have several studies revealed genus Carnobacterium in finfish intestine (Table 1). As the distal intestine (DI) is considered to be the primary site of intestinal absorption of macromolecules in salmonids (Ringø et al., 2003; Desai et al., 2012), Lyons et al. (2017a) “investigated the diversity of allochthonous and autochthonous bacteria in DI of rainbow trout (Oncorhynchus mykiss) by next generation sequencing (NGS) and revealed that carnobacteria were the most prevalent of the autochthonous LAB genera (6.2\%), and $4.15 \%$ of the allochthonous bacteria belonged to genus Carnobacterium." In an investigation evaluated the dietary effect of black soldier fly (Hermetia illucens) by DGGE, Bruni et al. (2018) reported Carnobacterium sp., and that $C$. divergens were one of the dominant bacterial species in the insect-fed groups vs. control fed fish.

\section{Lactobacillus}

Lactobacillus are acid-tolerant facultative anaerobes, and they are either homo- or heterofermentative. Kraus (1961) carried out the first study revealing that fish, herring (Clupea harengus L.), contained lactobacilli in the GI tract. Since this pioneer study was carried out, have several reviews revealed Lactobacillus species in the GI tract of several finfish species (e.g., Ringø and Gatesoupe, 1998; Ringø, 2004; Ringø et al., 2005; Gatesoupe, 2008; Lauzon and Ringø, 2011; Merrifield et al., 2014).

Table 1 show that Lactobacillus spp., Lb. aviarius, $L b$. aviaries subsp. arafinosus, Lactobacillus brevis, Lb. crispatus/Lb. amylovorus, $L b$. crispatus, $L b$. collinoides, $L b$. coryniformis, $L b$. farciminis, Lb. gallinarum, Lb. johnsonii, Lb. reuteri, and $L b$. sakei have been reported in the GI tract of several finfish species during the last 3 years. Characterization of the DI microbiome of rainbow trout from both farm and aquarium settings were investigated by Lyons et al. (2016). Differences were noted in the microbial community within the intestine of both populations, Phylum Firmicutes was slightly more prominent in the aquarium reared fish, and within principal OTUs were identified as Lactobacillus, Acetanaerobacterium, Catellicoccus, Streptococcus, Lactococcus, Leuconostoc, Enterococcus, Weissella, and Bacillus. Bahramian and Parsa (2017) revealed that culturable Lactobacillus spp. was reduced in the GI tract of rainbow trout fed diets supplemented with essential oil of Pistacia atlantica subsp. kurdica. In the study of Lyons et al. (2017a), the authors revealed that Lactobacillus was present in very low abundance $(0.1 \%)$, but a higher proportion (1.15\%) of Lactobacillus was displayed by the allochthonous microbiota in the DI of rainbow trout.

An interesting topic within gut bacterial adherence and colonization is; to how increase the relative abundance of beneficial Lactobacillus. In a recent study, (Liu W. et al., 2017) evaluated the effect of gut adhesive Lactobacillus strains and the combined effect of short chain fucto-oligosaccharides (scFOS) on growth performance, gut adhesive bacteria and disease resistance of juvenile tilapia, and concluded that scFOS increased the relative abundance of the Lactobacillus strains.

The effect of chromic oxide $\left(\mathrm{Cr}_{2} \mathrm{O}_{3}\right)$, one of the most widely used indicators for determination of nutrient digestibility in fish (Austreng, 1978; Ringø and Olsen, 1994), is less investigated in finfish studies. In three studies using Arctic charr (Salvelinus alpinus L.), Ringø (1993a,b, 1994) revealed that inclusion of 1\% $\left(\mathrm{Cr}_{2} \mathrm{O}_{3}\right)$ increased population level of culturable Lactobacillus and Streptococcus. In contrast, Serra et al. (2018) using the DGGE method to evaluate the gut microbiota of gilthead seabream (Sparus aurata) juvenile showed no effect of $0.5 \%$ inclusion level of $\mathrm{Cr}_{2} \mathrm{O}_{3}$ on number of operational taxonomic units, microbiota richness, diversity and similarity indices. The authors suggested that the difference between their results and Ringø's may be due to different inclusion level and the sharpening of the GI tract of the fish species.

\section{Lactococcus}

The genus Lactococcus is included within the family Streptococcacceae, and was described for the first time in 1985 after the division of genus Streptococcus, which included a group of microorganisms known as lactic streptococci represented by agents isolated from plant material, dairy cattle, and milk products (Schleifer et al., 1985). Lactococcus produce L (+) lactate from glucose as opposed to Leuconostoc produce D (-) lactate from glucose. One of the first studies isolating genus Lactococcus from finfish, common carp (Cyprinus carpio), was revealed by Cai et al. (1999), but later the genus has been isolated from the GI tract of several finfish species (Merrifield et al., 2014), and during the last years, numerous studies have revealed Lactococcus spp., L. lactis garvieae, L. lactis subsp. cremoris, L. piscium, and L. raffinolactis in the GI tract of finfish (Table 1). In their study with turbot (Scophthalmus maximus); autochthonous microbiota in the entire intestine, Yang et al. (2018) revealed that dietary stachyose significantly elevated the abundance of Lactococcus as well as Carnobacterium, Pediococcus, and Enterococcus. Li et al. (2015) used culturedependent and culture-independent techniques to investigate 
the autochthonous bacterial communities in the whole intestine of grass carp (Ctenopharyngodon idellus) (Valenciennes) and revealed seven culturable strains showing high similarity (99\%) to $L$. raffinolactis and one OUT similar to $L$. raffinolactis. Lyons et al. (2017a) revealed that both autochthonous and allochthonous Lactococcus was present in very low abundance ( 0.2 and $0.23 \%$, respectively) in the DI of farmed rainbow trout.

\section{Leuconostoc}

Leuconostoc spp. are generally ovoid cocci often forming chains; are resistant to vancomycin and are catalase-negative. All Leuconostoc species are heterofermentative, produce D (-) lactate from glucose and are able to produce dextran from sucrose, and are generally slime-producers. Species of genus Leuconostoc are isolated from different sources (Carr et al., 2002) as well as from the GI tract of finfish (Merrifield et al., 2014). Since 2016, genus Leuconostoc, both autochthonous and allochthonous, has been reported in the intestine of rainbow trout, Atlantic salmon and Arctic charr (Table 1).

\section{Pediococcus}

Pediococcus usually occur in pairs or tetrads, and divide along two planes of symmetry, and they are purely homofermentative. To our knowledge, the first studies to isolate Pediococcus from intestine of finfish was carried out in the late 90's by Cai et al. (1999) and Halami et al. (1999). During the last 3 years, only one study has revealed Pediococcus in the intestine of finfish, turbot, evaluating the effect of dietary stachyose; a significant higher abundance of Pediococcus was revealed in fish fed diet added 5\% stachyose (Yang et al., 2018).

\section{Streptococcus}

This genus has been subjected to important changes, as several species have been reclassified into genera Lactococcus, Enterococcus, and Vagococcus, based on biochemical characteristics and by molecular methods (Schleifer and Kilpper-Bälz, 1984; Schleifer et al., 1985; Collins et al., 1989). Species within genus Streptococcus have been isolated from several finfish species (Merrifield et al., 2014).

An overview of streptococci species revealed in the intestine of finfish since 2016 and until today is presented in Table $\mathbf{1 .}$ Lyons et al. (2017a) revealed that autochthonous Streptococcus was present in low abundance $(2.3 \%)$ in the DI of farmed rainbow trout, but a slightly higher abundance $(2.89 \%)$ was noticed by the allochthonous microbiota.

\section{Enterococcus}

Modern classification techniques of Enterococci resulted in the transfer of some members of genus Streptococcus, Lancefield's group D streptococci, to the new genus Enterococcus. Recently, Lyons et al. (2017a) revealed that autochthonous Enterococcus was present in low abundance $(1.72 \%)$ in the DI of farmed rainbow trout. In addition to Enterococcus spp., E. faecalis and Enterococcus faecium were isolated from the GI tract of mrigal (Cirrhinus mrigala) (Shahid et al., 2017) and European sea bass (Dicentrarchus labrax) (Torrecillas et al., 2017), respectively.

\section{Vagococcus}

Collins et al. (1989) proposed that on the basis of the present sequence data and earlier chemotaxonomic studies that the motile group Lancefield group $\mathrm{N}$ cocci strains be classified in a new genus Vagococcus. The first study isolated Vagococcus (Vagococcus fluvialis) from finfish intestine was displayed by González et al. (2000). Recently Lyons et al. (2017a) revealed that autochthonous Vagococcus was present in low abundance $(1.74 \%)$ in the DI of farmed rainbow trout, while the abundance of allochthonous Vagococcus was $0.72 \%$.

\section{Weissella}

Genus Weissella belongs to Leuconostocaceae family and are obligate heterofermentative, producing $\mathrm{CO}_{2}$ from carbohydrate metabolism with either D (-), or a mixture of D (-) - and L $(+)$-lactic acid and acetic acid as major end products from sugar metabolism. According to the review of Fusco et al. (2015), there are 19 Weissella species known. The first study revealing Weissella (W. confusa) from the intestinal tract of fish, seabass (Lates calcarifer), was carried out by Rengpipat et al. (2014). During the last 3 years, several studies have revealed Weissella in the digestive tract of finfish (Table 1). For example, Lyons et al. (2017a) revealed that both autochthonous and allochthonous Weissella was present in very low abundance $(0.1$ and $0.39 \%)$ in the DI of farmed rainbow trout.

\section{Bifidobacterium}

Bifidobacterium are commonly reported in the GI tract of endothermic animals, but they are only been isolated in few studies from the digestive tract of finfish (Merrifield et al., 2014). Recently, Boonanuntanasarn et al. (2017) revealed increased population level of Bifidobacterium spp. by feeding Nile tilapia (Oreochromis niloticus) fingerlings fed inulin and Jerusalem artichoke (Helianthus tuberosus).

\section{ANTIBACTERIAL EFFECTS OF LAB; BACTERIOCINS PRODUCED BY LAB}

Massive growth and intensification in aquaculture during the last decades has been associated with numerous problems; fish diseases caused by pathogenic bacteria being one of them (Sahoo et al., 2016). An array of conventional and advanced prophylactic or curative measures have been put forward to dispose of bacterial fish diseases, e.g., use of antibiotics (Burridge et al., 2010), vaccines (Gudding and Van-Muiswinkel, 2013), disinfectants, feed additives, dietary supplements, herbal immunostimulants (Newaj-Fyzul and Austin, 2014), prebiotics (Ganguly et al., 2012), and probiotics (e.g., Verschuere et al., 2000; Kesarcodi-Watson et al., 2008; Nayak, 2010; Pandiyan et al., 2013; Dawood and Koshio, 2016). The commonly use of disinfectants and antimicrobial agents as growth promotors and in disease control in aquaculture, increased the concern about the indiscriminate use due to the selective pressure on the intestinal microorganisms and development of antibiotic resistant bacteria (Cabello, 2006; Kolndadacha et al., 2011; Romero et al., 2012). As a natural consequence, there was seek for novel antibacterial compounds (preferably proteinaceous) with prophylactic or 
therapeutic potential and for which pathogens may not develop resistance (Patil et al., 2001; Sahoo et al., 2016).

The antibacterial agents are antibiotics, bacteriocins, lysozymes, proteases, siderophores, and/or hydrogen peroxide and acidic $\mathrm{pH}$ by organic acids production (De Vuyst and Leroy, 2007; Bindiya et al., 2015; Mukherjee et al., 2016).

Bacteriocins, are ribosomal-synthesized antimicrobial peptides, and $\mathrm{LAB}$ are the most common producers (Zacharof and Lovitt, 2012; Silva et al., 2018). They are small cationic molecules of 30-60 amino acids, form amphiphilic helices and are stable at $100^{\circ} \mathrm{C}$ for $10 \mathrm{~min}$. During the last decade probiotic $\mathrm{LAB}$ with antimicrobial potential has achieved interest in aquaculture (Muñoz-Atienza et al., 2013), and the use of bacteriocins as supplements or adjuncts could be an eco-friendly approach to alleviate antibiotic overuse and resistance (Lagha et al., 2017).

Fish could be a potential source of bacteriocin-producing (bacteriocinogenic) bacteria and extensive screening of gut associated microorganisms may be taken up to avoid the use of antibacterial drugs in aquaculture (Sahoo et al., 2016). Reports indicated that the LAB isolated from diverse fish species, other aquatic organisms, culture water and sediments possess antagonistic activity against the fish pathogens (Balcázar et al., 2007a,b; Sugita et al., 2007; Ringø, 2008; Shahid et al., 2017). Hence, the potential use of bacteriocinogenic LAB as probiotics and bio-protective agents has received growing attention during the last decade (e.g., Gillor et al., 2008; Satish Kumar et al., 2011; Heo et al., 2012). According to Elayaraja et al. (2014), genera Lactobacillus, Lactococcus, Streptococcus, Pediococcus, Oenococcus, Enterococcus, Leuconostoc, and Carnobacterium produce a variety of bacteriocins. Numerous investigations on isolation and characterization of bacteriocins and bacteriocinogenic LAB from different sources are available, however, lesser research has been done on bacteriocins of LAB from fish (Gómez-Sala et al., 2015).

This section will present an overview on the beneficial attributes that might be associated with the use of bacteriocins and bacteriocinogenic $\mathrm{LAB}$ in aquaculture, diverse classes of bacteriocins produced by $\mathrm{LAB}$, methods to characterize bacteriocins and an update on the efficacy of LAB against fish pathogens.

\section{BENEFITS ASSOCIATED WITH THE LAB AND BACTERIOCINS PRODUCED BY LAB}

Interest on bacteriocinogenic bacteria, especially LAB, has achieved huge impetus due to its potential as both, probiotics and therapeutic antibiotics (Gillor et al., 2008; Cotter et al., 2013; Perez et al., 2014). Bacteriocins have several positive attributes that made them especially attractive for application in various sectors including aquaculture (Perez et al., 2014).

1. LAB and its metabolites are generally regarded as safe for human consumption, as they are found or used in food and fermented food products (FAO/WHO, 2002). Thus, aquatic organisms produced with application of LAB or bacteriocins thereof could be considered as safe for human consumption.
2. LAB bacteriocins are tolerant to high thermal stress and their activity over a wide $\mathrm{pH}$ range are well-known. Therefore, if applied as aquafeed supplement, efficacy of the bacteriocins from $\mathrm{LAB}$ is expected to be retained within the fish GI tract.

3. Bacteriocins forms pores in the target membrane of bacteria, even at extremely low concentrations.

4. These microbial metabolites are colorless, odorless, and tasteless, and therefore, do not interfere with acceptability of the diet if used as a supplement.

5. To our knowledge, there are no documentation on the development of resistant bacteria.

6. Bacteriocins usually have low molecular weight (rarely over 10 $\mathrm{kDa}$ ), and they undergo posttranslational modification. Being proteinaceous, they can be easily degraded by the proteolytic enzymes of the host (Zacharof and Lovitt, 2012). Therefore, bacteriocin fragments do not live long either in the host or in the environment, thus minimizing the opportunity of target strains to interact with the degraded fragments and development of resistance.

7. Bacteriocins are ribosomally synthesized and produced during the primary phase of growth unlike antibiotics, which are usually secondary metabolites (Beasley and Saris, 2004). Bacteriocins generally restrict their activity to the strains of species closely related to the producer strain (Lisboa et al., 2006; Bakkal et al., 2012); compared to antibiotics having wider activity spectrum (broad-spectrum).

8. Not only antagonistic against some fish pathogens, bacteriocin has also been reported to be an important molecule in quorum sensing process (Czaran et al., 2002; Gobbetti et al., 2007). In fact, quorum sensing has been believed to be responsible for the expression of genes that code for bacteriocins in LAB. To outcompete the related species, sensing of its own growth enables the LAB to switch on bacteriocin production when competition for nutrients is likely to become more severe (Eijsink et al., 2002).

\section{CLASSES OF BACTERIOCINS PRODUCED BY LAB}

Gram-positive bacteria account for the majority of bacteriocins recorded per se (Rather et al., 2017), although bacteriocins are also revealed in Gram-negative (Sahoo et al., 2016). Among the Gram-positive bacteria, bacteriocins produced by LAB have gained particular attention nowadays. However, to deal with, firstly we need to see the classes of bacteriocins produced by diverse bacteria and then bacteriocins produced by LAB may be narrowed down.

Bacteriocin classification is an ongoing subject of debate, and therefore, proper classification is yet to be established (Desriac et al., 2010). A variety of criteria or their combinations are proposed as the basis for bacteriocin classification. For example, the producer bacterial family, molecular weights, amino acid composition, sequence homologies, primary structures, organization of the gene cluster (Hammami et al., 2010), mechanism of action and Gram designation. Bacteriocins were primarily divided into four classes (Klaenhammer, 1993). The 
TABLE 2 | Different classes of bacteriocins produced by the LAB.

\begin{tabular}{|c|c|c|c|c|}
\hline Classes & Characteristic features & Bacteriocins produced & $\begin{array}{l}\text { Typical producer } \\
\text { organism }\end{array}$ & References \\
\hline Class I: Lantibiotics & $\begin{array}{l}\text { Lantibiotics, small ( }<5 \mathrm{kDa} \text { ) peptides } \\
\text { containing lanthionine and } \\
\text { b-methyllanthionine }\end{array}$ & Nisin, lactocin, mersacidin & Lb. lactis subsp. lactis & Parada et al., 2007 \\
\hline $\begin{array}{l}\text { Class II: } \\
\text { Non-lantibiotics }\end{array}$ & $\begin{array}{l}\text { Small ( }<10 \mathrm{kDa}) \text {, heat-stable, } \\
\text { non-lanthionine-containing peptides }\end{array}$ & & & \\
\hline Class Ila & $\begin{array}{l}\text { Heat stable, non-modified, cationic, } \\
\text { hydrophobic peptides; contain a } \\
\text { double-glycine leader peptide; } \\
\text { pediocin-like peptides }\end{array}$ & $\begin{array}{l}\text { Pediocin PA1, sakicin A, } \\
\text { leucocin A }\end{array}$ & Lc. gelidum & Todorov, 2009 \\
\hline Class IIb & $\begin{array}{l}\text { Require synergy of two } \\
\text { complementary peptides; mostly } \\
\text { cationic peptides }\end{array}$ & $\begin{array}{l}\text { Lactococcin G, plantaricin } \\
\text { A, enterocin X }\end{array}$ & E. faecium & Perez et al., 2014 \\
\hline Class Ilc & $\begin{array}{l}\text { Affect membrane permeability and } \\
\text { cell wall formation }\end{array}$ & $\begin{array}{l}\text { Acidocin } B \text {, entereocin } P \text {, } \\
\text { reuterin } 6\end{array}$ & Lb. acidophilus & $\begin{array}{l}\text { Šušković et al., } \\
2010\end{array}$ \\
\hline $\begin{array}{l}\text { Class III: Large heat } \\
\text { labile bacteriocins }\end{array}$ & $\begin{array}{l}\text { Heat sensitive peptides, large } \\
\text { molecular mass (>30 kDa) }\end{array}$ & $\begin{array}{l}\text { Lysostaphin, enterolysin A, } \\
\text { helveticin J }\end{array}$ & Lb. helveticus & Cotter et al., 2005 \\
\hline
\end{tabular}

Adapted and modified from Sahoo et al. (2016) and Mokoena (2017).

Class I bacteriocins are called lantibiotics, represented by nisin and lactocin, gathers very low molecular weight $(<5 \mathrm{kDa})$ thermostable peptides, characterized by the post-translational modification and presence of lanthionine or derivatives. The Class II bacteriocins consist of small thermostable peptides $(<10$ $\mathrm{kDa}$ ) divided into three subclasses: IIa (pediocin and enterocin), IIb (lactocin G) and IIc (lactocin B). They are usually nonmodified peptides, cationic, hydrophobic and often amphiphilic reflecting their ability to act on target cells by permeabilizing the cell membrane. Class IIa bacteriocins, the mostly studied LAB bacteriocins possessed strong antimicrobial properties against a broad range of Gram-positive spoilage and food-borne pathogens (Sahoo et al., 2016). The Class III bacteriocins having high molecular weight $(>30 \mathrm{kDa})$, thermolabile peptides such as the helveticin J, while in the Class IV we can find large complexes of peptides with carbohydrates or lipids. Cotter et al. (2005) suggested a new classification; dividing bacteriocins into two categories: lantibiotics (Class I) and not containing lanthionine lantibiotics (Class II), while high molecular weight thermolabile peptides formally recognized under the above class III, would be separately re-classified as "bacteriolysins," i.e., hydrolytic polypeptides. Thus, finally bacteriocins are divided into three major classes according to their genetic and biochemical characteristics (Drider et al., 2006). Consequently, different types of bacteriocins produced by the LAB are now classified (Table 2) as: Class I or Lantibiotics $(<5 \mathrm{kDa})$, Class II or Non-Lantibiotics (usually $<10 \mathrm{kDa}$ ) and Class III bacteriocins (generally $>30$ $\mathrm{kDa}$ ) (Ghosh et al., 2014).

\section{SCREENING AND CHARACTERIZATION OF BACTERIOCINS PRODUCED BY LAB}

Bacteriocins are ribosomally synthesized peptides, which are usually synthesized as inactive precursors of peptides having an N-terminal sequence and later modified to attain an active state (Todorov, 2009; Perez et al., 2014). The activity of bacteriocins produced by different $\mathrm{LAB}$ is not uniform and constant, and depends on the physico-chemical composition of the microbial growth media (Balciunas et al., 2013). For aquaculture application of either bacteriocinogenic LAB or their bacteriocins, screening of efficient organism is a prerequisite. Bacteriocinogenic potential of a strain can be studied either by culture-dependent methods or by molecular methods employing PCR amplification of known bacteriocin structural genes. Initial screening to detect and determine the antibacterial activities of bacteriocinogenic strains can be done by an agar spot test (Schillinger and Lücke, 1989) or by agar well diffusion assay (Srionnual et al., 2007); using some indicator strains, e.g., Lb. sakei ssp. sakei JCM 1157T and Listeria monocytogenes ATCC 19111 (Lin et al., 2012). Then, antibacterial activity of the crude bacteriocin or bacteriocin like inhibitory substance (BLIS) may be further confirmed and optimized by characterization of the cell-free supernatants through $\mathrm{pH}$ and temperature adjustments, and proteinase- $\mathrm{K}$ treatment (Lin et al., 2012). For molecular detection of bacteriocinogenic potential, PCR amplification of known bacteriocin structural genes can be performed using the specific primers. For example, enterocin structural genes may be amplified with specific primers like EnterA-F/EnterA-R for detection of enterocin A (entA), EntB3/EntB5 for enterocin B (entB), EntP1/EntP2 for enterocin $\mathrm{P}$ (entP), and so on (Almeida et al., 2011; Gómez-Sala et al., 2015).

For application of bacteriocinogenic LAB as probiotics, screening and determination of potent LAB strain would be sufficient. However, for application of purified bacteriocin as feed supplement, production of pure bacteriocin and determination of molecular mass seem to be essential. Purification can be done by several steps as depicted in Figure 1: ammonium sulfate 


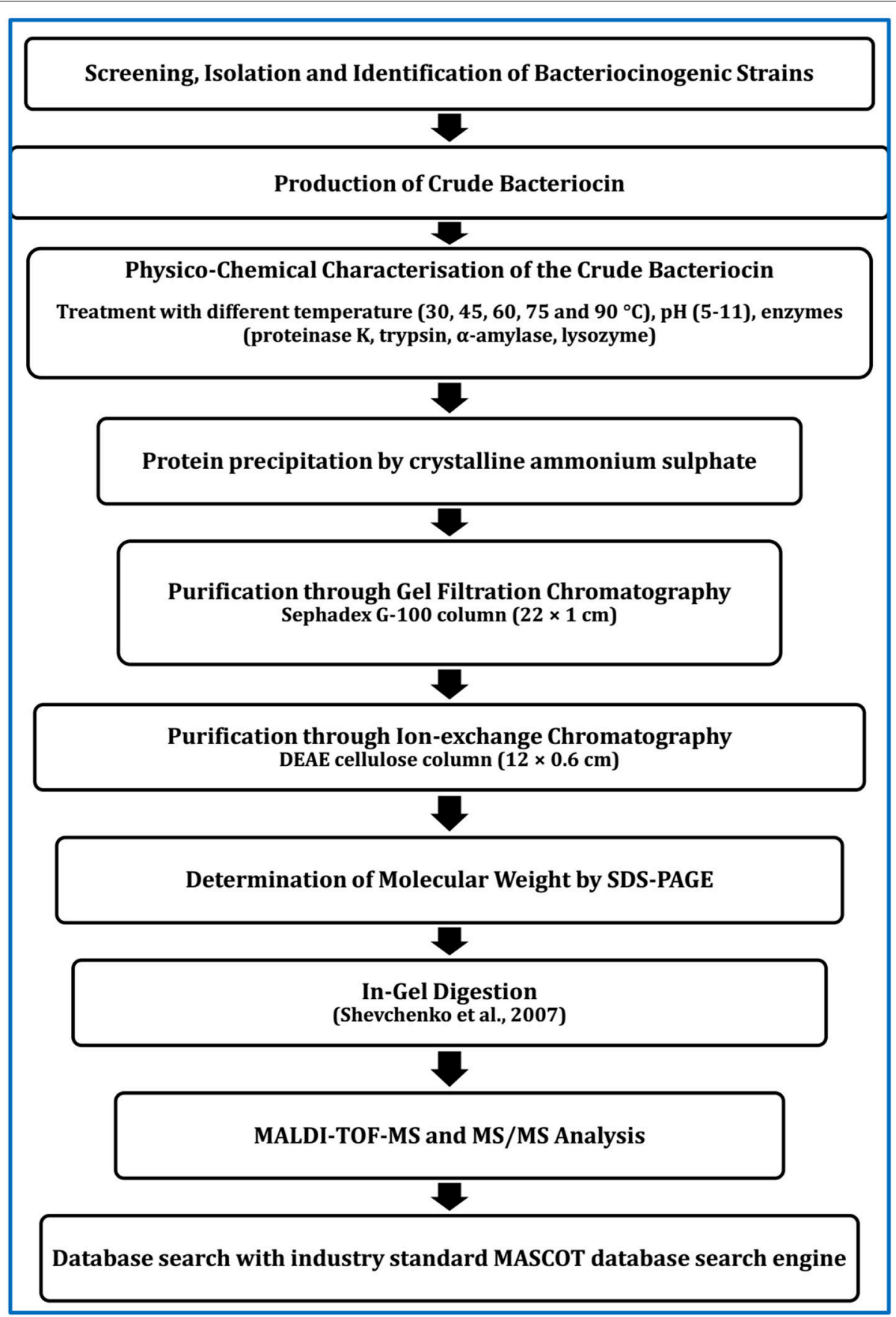

FIGURE 1 | Scheme for purification of bacteriocins produced by LAB or other bacteria.

precipitation, gel filtration chromatography followed by ionexchange chromatography. The active fraction that would display maximum antibacterial activity should be collected and used for further studies. The purity, homogeneity and molecular size of BLIS can be determined using sodium dodecyl sulfatepolyacrylamide gel electrophoresis (SDS-PAGE) (Srionnual et al., 2007). The molecular mass of the purified bacteriocin can be determined by matrix-assisted laser desorption/ionization timeof-flight (MALDI-TOF) mass spectrometry (MS) using a mass spectrometer and database search through Mascot search engine (Lin et al., 2012).

As per as aquaculture application is concerned, the use of purified bacteriocins is still a question mark, as the major apprehension would be administration of the compounds to 
the farmed fish that are aquatic. Numerous studies have recommended the bacteriocinogenic strains to be used as aquaculture probiotics (Irianto and Austin, 2002; Gatesoupe, 2008; Issazadeh et al., 2012). This is indeed a more reasonable and practical approach than direct application of purified bacteriocins in consideration of the fact that the probiotic strains are live cultures and thus able to ultimately establish themselves in the hosts and the aquatic environment (Rather et al., 2017).

\section{ACTIVITY OF BACTERIOCINOGENIC LAB AGAINST FISH PATHOGENS: AN UPDATE}

It has been predicted that application of bacteriocins/BLIS from $\mathrm{LAB}$ or bacteriocinogenic LAB might not only effective in preventing diseases, but also minimize the risks of using broadspectrum antibiotics in aquaculture. In aquaculture, numerous studies have indicated the potential use of bacteriocinogenic $\mathrm{LAB}$ as biocontrol agents against pathogens (e.g., Gillor et al., 2008; Desriac et al., 2010; Satish Kumar et al., 2011; Heo et al., 2012). Apart from LAB of fish origin, LAB from nonfish sources has also been tested to accomplish health benefits or disease prevention and achieved experimental success. For example, administration of the human probiotic, Lactobacillus rhamnosus 53101, reduced mortalities from 52.6 to $18.9 \%\left(10^{9}\right.$ cells/g of feed) and to $46.3 \%$ ( $10^{12}$ cells/g of feed) in rainbow trout following challenge with Aeromonas salmonicida (Nikoskelainen et al., 2001). Furthermore, LAB-produced bacteriocins have been applied as bio-preservatives in marine food products and have shown to control pathogenic and spoilage microorganisms (CaloMata et al., 2007; Yin et al., 2007; Diop et al., 2009; Chahad et al., 2012).

To avoid harmful effects on the host fish as well as on the indigenous microbiota, use of autochthonous bacteria or their metabolites might be preferred to use vs. allochthonous. In aquaculture, the justification of using $\mathrm{LAB}$ or bacteriocinogenic $\mathrm{LAB}$ isolated from the autochthonous microbiota is based on the fact that the producer bacterial strains occupy more or less the same ecological niche with the pathogens and hosts of concern (Prasad et al., 2005; Zai et al., 2009). Antagonistic activity of LAB isolated from fish intestine against fish pathogens i.e., furunculosis, columnaris, peduncle disease, streptococcosis have been documented (e.g., Gutowska et al., 2004; Ringø et al., 2005; Sugita and Ito, 2006; Sahoo et al., 2016; Banerjee and Ray, 2017). Although, bacteriocins characterized from fish-and aquatic bacteria are scarce (Table 3 ), most of the characterized bacteriocins of aquatic origin that have antagonistic activity against many bacterial pathogens are isolated from marine aquaculture, while few from freshwater (Sahoo et al., 2016).

It has been predicted that Pscicocin V1a and Pscicocin V1b isolated from C. piscicola CS526 and C. piscicola V1, respectively could prevent haemorrhagic septicaemia caused by Pseudomonas sp. (Bhugaloo-Vial et al., 1996). In another report, Phocaecin PI80 bacteriocin produced by Streptococcus phocae PI80 isolated from the gut of Indian white shrimp (Peneaus indicus) has been documented that might prevent Vibrio septicaemia caused by Vibrio sp. (Kumar and Arul, 2009). Likewise, BLIS AP8 from Lactobacillus casei AP8 and bacteriocin like inhibitory (substance) $\mathrm{H} 5$ from $L b$. plantarum $\mathrm{H} 5$ might be effective against haemorrhagic septicaemia and Vibrio septicaemia (Ghanbari et al., 2013), although their mode of action is yet to be confirmed. In addition, the bacteriocin-producing LAB from aquatic organisms including fish include enterocin $\mathrm{P}$ produced by E. faecium isolated from turbot (Arlindo et al., 2006), nisin F produced by L. lactis from freshwater catfish (Clarias gariepinus) (De Kwaadsteniet et al., 2008), and divercins and piscicocins produced by Carnobacterium spp. (Desriac et al., 2010).

Although several reports have shown promising results regarding the aquaculture potential of bacteriocinogenic LABs or their bacteriocins from aquatic sources, subsequent studies are still needed to substantiate its viability in field condition with large number of organisms (Rather et al., 2017). Moreover, application strategy of the bacteriocins from LAB maintaining its effectiveness should be standardized so as to explore its potential in the disease prevention and sustainability of the aquaculture industry.

\section{LAB AS PROBIOTIC}

During the last years, numerous LAB strains have been used as probiotics in finfish aquaculture due to their health beneficial effect (Table 4). According to Belicova et al. (2013) an organism should be defined as probiotic when it is non-pathogenic, reveal antibacterial activities toward potential pathogens, tolerate low $\mathrm{pH}$, high concentrations of conjugated, and de-conjugated bile salts, be accepted by the immune system, and not result in formation of antibodies. In addition, the probionts must not transfer antibiotic resistance genes to pathogens through horizontal gene transfer.

Considering the potential of $\mathrm{LAB}$ as feed additive in aquaculture there is extensive literatures available. The researchers investigated possible effects on growth performance, feed utilization, digestive enzymes activity, immune response, and disease resistance. Despite some contradictory results, most of the studies revealed beneficial effects on measured parameters. This section present an overview on available literatures regarding $\mathrm{LAB}$ administration as probiotic in aquaculture. To avoid overlap with previous reviews, we have focused on the papers published from 2014. Readers with special interests on previous studies, are referred to the reviews of Ringø and Gatesoupe (1998), Nayak (2010), Carnevali et al. (2014), Castex et al. (2014), De et al. (2014), Lauzon et al. (2014), Merrifield et al. (2014), Ringø et al. (2014) and Hoseinifar et al. (2016c).

\section{Lactobacillus spp. Lactobacillus plantarum}

Within lactobacilli, Lb. plantarum is the most studied strain. Piccolo et al. (2015) evaluated the effects of dietary Lb. plantarum on performance and serum biochemical parameters of European sea bass. The inclusion level was $10 \times 10^{9} \mathrm{CFU} / \mathrm{kg}$ and fishes were fed on the probiotic supplemented diet for 90 days and probiotic feeding revealed noticeable effect on growth performance vs. control. Regarding serum biochemical parameters only total cholesterol and triglycerides were studied, but a significantly 
TABLE 3 | Bacteriocins from $L A B$ characterized and identified from aquatic resources.

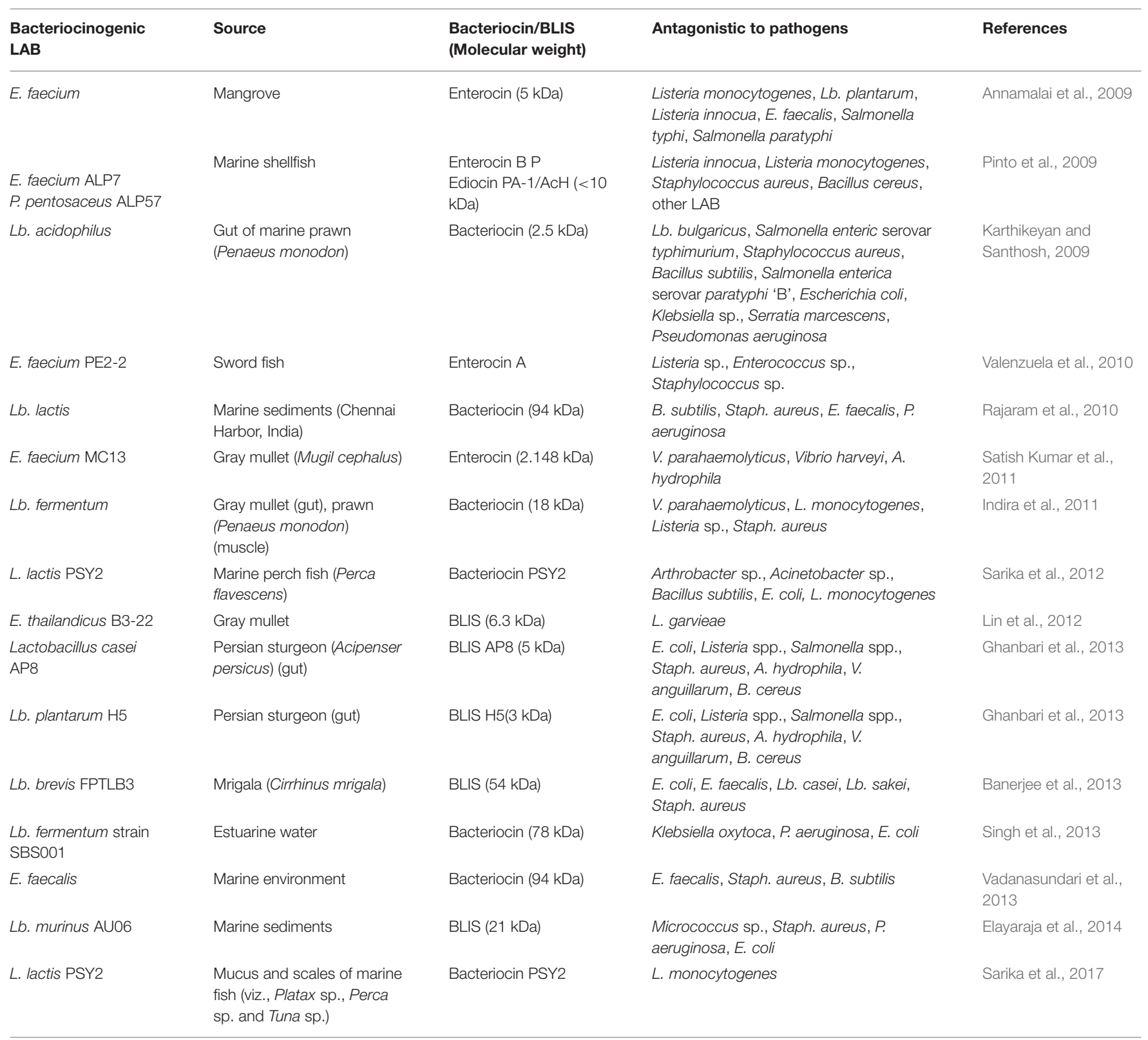

increased following probiotic administration was revealed. In a 72-days feeding trial, Soltani et al. (2017a) fed rainbow trout (vaccinated to yersiniosis) a probiotic diet containing Lb. plantarum, $2 \times 10^{7} \mathrm{CFU} \mathrm{g}^{-1}$. At the end of the trial, the vaccinated fish fed the probiotic diet had noticeably higher lysozyme and alkaline phosphatase compared to the other treatments. Besides, improved growth performance was noticed in the vaccine + probiotic treatment vs. the others. However, no significant difference among different treatments in case of hameato-immunological parameters as well as LAB levels in intestinal microbiota were revealed. The authors concluded that administration of probiotics following vaccination can be considered as beneficial by increasing vaccines efficacy.
The same research group, Kane et al. (2016), evaluated the effects of $10^{8} \mathrm{CFU} \mathrm{g} \mathrm{g}^{-1}$ of $\mathrm{Lb}$. plantarum on serum biochemical as well as immune responses in rainbow trout treated with streptococcosis/lactococosis vaccine, and revealed that feeding Lb. plantarum to immunized fish resulted in significant increase of immune parameters such as lysozyme, alternative complement activities, antibody titer, total leukocytes and lymphocytes, and serum biochemical parameters. Moreover, Soltani et al. (2017b) supplemented a common carp diet with different levels $\left(1.2 \times 10^{6}, 0.9 \times 10^{6}\right.$, and $\left.0.56 \times 10^{6} \mathrm{CFU} / \mathrm{g}\right)$ of $\mathrm{Lb}$. plantarum, and after 80 days feeding; significantly improved growth performance and immune parameters compared to the control treatment was noticed. However, 
TABLE 4 | An overview on LAB used as probiotic in finfish aquaculture.

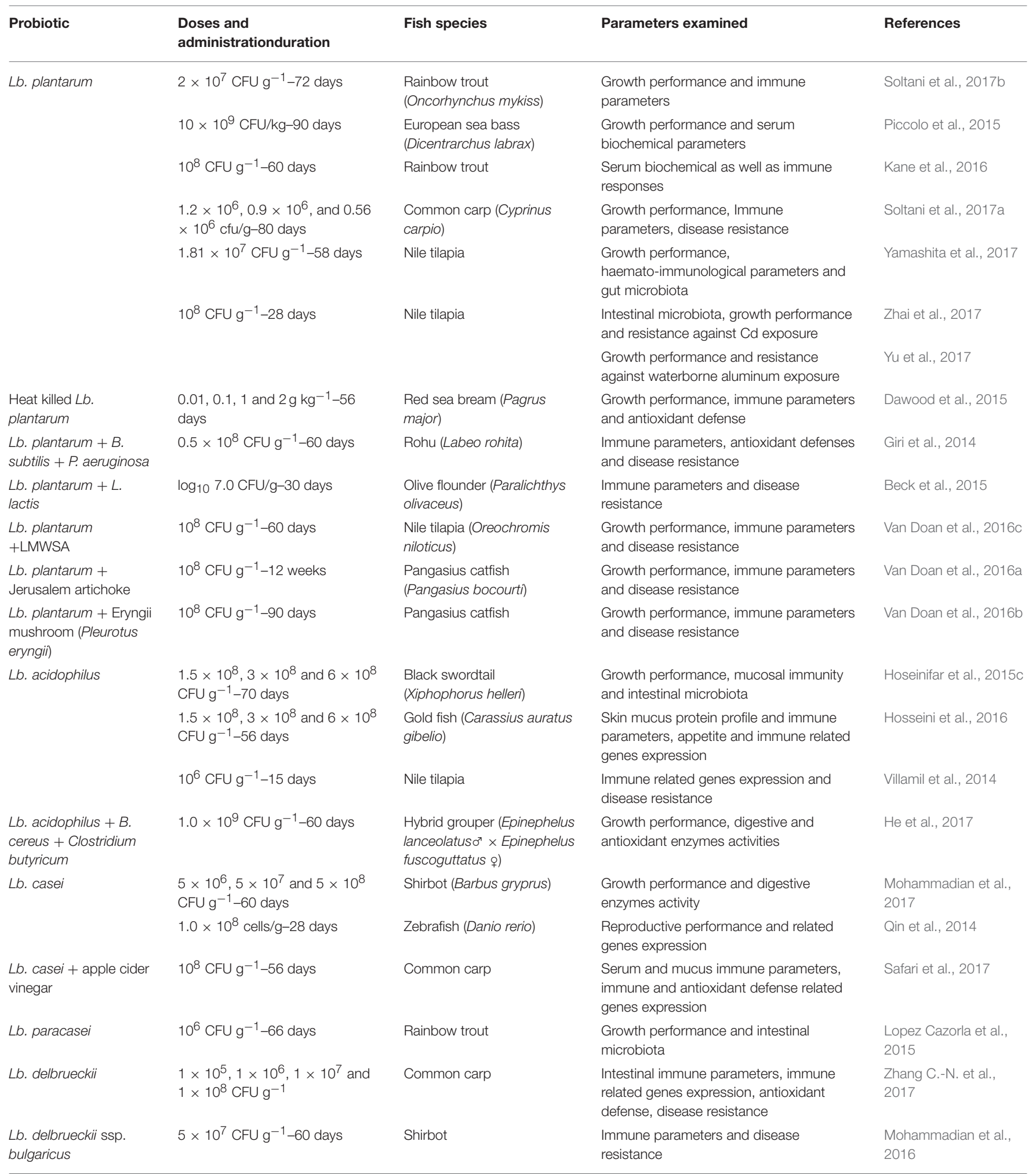


TABLE 4 | Continued

\begin{tabular}{|c|c|c|c|c|}
\hline Probiotic & $\begin{array}{l}\text { Doses and } \\
\text { administrationduration }\end{array}$ & Fish species & Parameters examined & References \\
\hline \multirow[t]{3}{*}{ Lb. rhamnosus } & $\begin{array}{l}10^{3}, 10^{5} \text { and } 10^{6} \mathrm{CFU} / \mathrm{g}-63 \\
\text { days }\end{array}$ & $\begin{array}{l}\text { European eel (Anguilla } \\
\text { anguilla) }\end{array}$ & $\begin{array}{l}\text { Sperm quality and quantity, expression of } \\
\text { genes related to spermatogenesis }\end{array}$ & Vílchez et al., 2015 \\
\hline & $\begin{array}{l}1 \times 10^{2}, 1 \times 10^{4} \text { and } 1 \times 10^{6} \\
\text { cells } g^{-1}-56 \text { days }\end{array}$ & Red sea bream & Plasma and mucus parameters & Dawood et al., 2017 \\
\hline & $10^{7}$ and $10^{8} \mathrm{CFU} \mathrm{g} \mathrm{g}^{-1}-56$ days & Rainbow trout & $\begin{array}{l}\text { Intestinal microbiota and histology, } \\
\text { biochemical parameters, and antioxidant } \\
\text { defense }\end{array}$ & $\begin{array}{l}\text { Topic (Popovic et al., } \\
\text { 2017) }\end{array}$ \\
\hline $\begin{array}{l}\text { Lb. rhamnosus+ Lb. } \\
\text { lactis }\end{array}$ & $10^{6} \times$ cell/g-56 days & Red sea bream & $\begin{array}{l}\text { Immune parameters and antioxidant } \\
\text { defense }\end{array}$ & Dawood et al., 2016b \\
\hline \multirow[t]{2}{*}{ P. acidilactici } & $10^{6} \mathrm{CFU} / \mathrm{g}-10$ days & Zebrafish & $\begin{array}{l}\text { Expression of genes related to male and } \\
\text { sperm quality }\end{array}$ & Valcarce et al., 2015 \\
\hline & $1 \mathrm{~g} \mathrm{~kg}^{-1}-56$ days & $\begin{array}{l}\text { Green terror (Aequidens } \\
\text { rivulatus) }\end{array}$ & $\begin{array}{l}\text { Innate immune parameters and resistance } \\
\text { to hypoxia stress }\end{array}$ & Neissi et al., 2013 \\
\hline $\begin{array}{l}\text { P. acidilactici+ } \\
\text { galactooligosaccharide } \\
\text { (GOS) }\end{array}$ & $7.57 \log$ CFU g ${ }^{-1}-56$ days & Rainbow trout & $\begin{array}{l}\text { Growth performance, immune parameters } \\
\text { and disease resistance }\end{array}$ & $\begin{array}{l}\text { Hoseinifar et al., } \\
2015 a, b, 2016 a\end{array}$ \\
\hline P. acidilactici+ GOS & $7.57 \log$ CFU g ${ }^{-1}-56$ days & Common carp & $\begin{array}{l}\text { Immune parameters and related genes } \\
\text { expression }\end{array}$ & Modanloo et al., 2017 \\
\hline \multirow[t]{3}{*}{ P. pentosaceus } & $\begin{array}{l}6 \times 10^{10}, 1.6 \times 10^{11}, 1.6 \times \\
10^{12} \text { and } 3.2 \times 10^{12} \text { cells } \\
g^{-1}-56 \text { days }\end{array}$ & Red sea bream & $\begin{array}{l}\text { Skin mucus and serum immune } \\
\text { parameters, resistance to low-salinity } \\
\text { stress }\end{array}$ & Dawood et al., 2016a \\
\hline & $\begin{array}{l}2 \times 10^{7}, 2 \times 10^{8} \text { and } 2 \times 10^{9} \\
\text { CFU g }{ }^{-1}-56 \text { days }\end{array}$ & Siberian sturgeon & Intestinal and body composition & Moslehi et al., 2016 \\
\hline & $10^{9} \mathrm{CFU} \mathrm{g}^{-1}-21$ days & $\begin{array}{l}\text { Orange-spotted grouper } \\
\text { (Epinephelus coioides) }\end{array}$ & $\begin{array}{l}\text { Growth performance, immune related } \\
\text { genes expression and disease resistance }\end{array}$ & $\begin{array}{l}\text { Huang J.-B. et al., } \\
2014\end{array}$ \\
\hline W. cibaria & $1.18 \times 10^{7} \mathrm{CFU} \mathrm{g}^{-1}-45$ days & Brazilian native surubins & $\begin{array}{l}\text { Growth performance, } \\
\text { haemato-immunological parameters and } \\
\text { intestinal histomorphology }\end{array}$ & Jesus et al., 2017 \\
\hline $\begin{array}{l}\text { Lc. mesenteroides }+E \text {. } \\
\text { faecalis }+L b \text {. } \\
\text { fermentum }\end{array}$ & $\begin{array}{l}10^{5}, 10^{7} \text { and } 10^{9} \mathrm{CFU} \mathrm{g}^{-1}-56 \\
\text { days }\end{array}$ & $\begin{array}{l}\text { Javanese carp (Puntius } \\
\text { gonionotus) }\end{array}$ & $\begin{array}{l}\text { Growth performance, intestinal microbiota } \\
\text { and body composition }\end{array}$ & Allameh et al., 2016 \\
\hline L. lactis WFLU12 & $10^{9} \mathrm{CFU} \mathrm{g}^{-1}-56$ days & Olive flounder & $\begin{array}{l}\text { Growth performance, immune parameters } \\
\text { and disease resistance }\end{array}$ & Nguyen et al., 2017 \\
\hline E. faecium & $10^{7} \mathrm{CFU} / \mathrm{g}-35$ days & Javanese carp & $\begin{array}{l}\text { Digestive enzymes activity, intestinal short } \\
\text { chain fatty, disease resistance }\end{array}$ & Allameh et al., 2015 \\
\hline E. gallinarum L-1 & $\begin{array}{l}10^{6}, 10^{7} \text {, and } 10^{8} \mathrm{cfu} \mathrm{mL}^{-1}-28 \\
\text { days }\end{array}$ & $\begin{array}{l}\text { Sea bream, European sea } \\
\text { bass, meager (Argyrosomus } \\
\text { regius) and red porgy } \\
\text { (Pagrus pagrus) }\end{array}$ & $\begin{array}{l}\text { Immune parameters and peroxidase } \\
\text { content }\end{array}$ & Román et al., 2015 \\
\hline E. casseliflavus & $\begin{array}{l}10^{7}, 10^{8} \text {, and } 10^{9} \mathrm{CFU} \mathrm{g}^{-1}-56 \\
\text { days }\end{array}$ & Rainbow trout & $\begin{array}{l}\text { Intestinal microbiota, humoral immune } \\
\text { parameters and disease resistance }\end{array}$ & Safari et al., 2016 \\
\hline
\end{tabular}

probiotic administration had no significant effect on liver enzymes level. The challenge test showed that probiotic fed fish had higher resistance against Aeromonas hydrophila. When discussing the effect of probiotic toward disease resistance, Fečkaninová et al. (2017) reviewed and highlighted the potential of LAB to protect against different Aeromonas spp. in salmonid aquaculture.

The possible effects of $L b$. plantarum on growth performance, haemato-immunological factors, intestinal microbiota and histology as well as disease of Nile tilapia was studied by Yamashita et al. (2017). Interestingly, dietary administration of $L b$. plantarum increased LAB level and decreased Vibrionaceae counts in intestinal microbiota. Besides, feeding on probiotic improved growth performance and feed utilization, while no significant difference was observed pre-challenge, but probiotic fed fish showed improved hematological parameter postchallenge. On the other hand, histological evaluations, intestinal epithelium structure, revealed no significant difference between probiotic treatment and control fed fish. In a study using Nile tilapia, Zhai et al. (2017) evaluated the protective effects of $10^{8}$

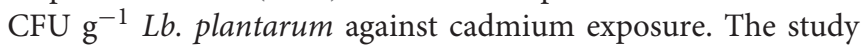
included four treatments; control, probiotic, $\mathrm{Cd}$ exposure and $\mathrm{Cd}$ exposure + probiotic. The exposure with $\mathrm{Cd}$ drastically decreased the richness of intestinal microbiota. However, feeding with probiotic reversed the changes were revealed. In addition, the highest growth performance was noticed in fish 
fed probiotics. The protective effects of $L b$. plantarum against waterborne aluminum exposure of tilapia by Yu et al. (2017), revealed that fish fed $L b$. plantarum CCFM639 significantly increased growth performance and alleviated aluminum damages. The effect of different levels of Lb. plantarum $\left(1 \times 10^{7}\right.$, $1 \times 10^{8}$, and $1 \times 10^{9} \mathrm{CFU} \mathrm{g^{-1 }}$ ) on growth performance and immune parameters in Siberian sturgeon (Acipenser baerii) were investigated by Pourgholam et al. (2016). Compared to control treatment, significant increase of innate immune parameters were noticed in probiotic fed fish, and the highest level of immunity was observed in fish fed $1 \times 10^{8} \mathrm{CFU} \mathrm{g}^{-1}$ probiotic as well as improvements of growth performances.

Dietary administration of head-killed probiotic has been suggest as efficient and safe feed additive in aquaculture (Yan et al., 2016). Beside working on live Lb. plantarum, the efficacy of dead Lb. plantarum was evaluated by Dawood et al. (2015). Red sea bream (Pagrus major) with average weight of $11 \mathrm{~g}$ were fed different levels $\left(0.01,0.1,1\right.$, and $\left.2 \mathrm{~g} \mathrm{~kg}^{-1}\right)$ of heat killed $L b$. plantarum for 56 days. The results revealed improved growth performance, immune parameters as well as antioxidant defense. The author displayed that $1 \mathrm{~g} \mathrm{~kg}^{-1}$ was the best inclusion level of heat killed $L b$. plantarum for Red sea bream. However, as there is limited information available on the use of dead or inactivated probiotics on other species, this topic merits further investigations.

A review of the literature showed that, $L b$. plantarum has been used as multi-strain probiotic and in combination with Bacillus subtilis VSG1 and Pseudomonas aeruginosa VSG2 (Giri et al., 2014), and feeding rohu (Labeo rohita) a multi-strain probiotic supplemented diet increased immune parameters, antioxidant defenses as well as disease resistance. The study also revealed that multi-strain administration was more efficient than single administration. In a study with olive flounder (Paralichthys olivaceus) fed Lb. plantarum FGL0001 and Lac. lactis BFE920 as multi-strain probiotics (Beck et al., 2015), the authors observed higher immune parameters and disease resistance in fish fed multi-strain probiotic vs. individual probiotic.

Gibson and Roberfroid (1995) proposed the synbiotics (a combination of pro- and prebiotics) concept; "characterize some colonic foods with interesting nutritional properties that make these compounds candidates for classification as health-enhancing functional ingredients." This concept is well used in endothermic studies (e.g., DuPont and DuPont, 2011; Ford et al., 2014) as well as in fish (Ringø and Song, 2016). Van Doan et al. (2016a) evaluated combined administration of low molecular weight sodium alginate (LMWSA) as prebiotic with $L b$. plantarum in Nile tilapia diet, and concluded that co-application increased the immunomodulatory effect as well as disease protecting effects of $L b$. plantarum. Similar results were observed when Jerusalem artichoke (Van Doan et al., 2016b) or Eryngii mushroom (Pleurotus eryngii) (Van Doan et al., 2016c) were used in combination with Lb. plantarum in a diet fed to Pangasius catfish (Pangasius bocourti).

\section{Lactobacillus acidophilus}

Lactobacillus acidophilus has been used as common probiotic in aquatic animals. Hoseinifar et al. (2015c) addressed the effects of different dose of $L b$. acidophilus $\left(1.5 \times 10^{8}, 3\right.$ $\times 10^{8}$, and $6 \times 10^{8} \mathrm{CFU} \mathrm{\textrm {g } ^ { - 1 }}$ ) on intestinal microbiota, mucosal immune parameters as well as stress resistance in black swordtail (Xiphophorus helleri). At the end of feeding trial, the probiotic strain successfully colonized the intestine and the dose of LAB significantly increased. Probiotic treatment, also increased growth performance as well as skin mucus immunity. Swordtail fish fed with $L b$. acidophilus showed significantly higher resistance when exposed to salinity stress test. In another study with ornamental fish, Hosseini et al. (2016) investigated possible effects of $L b$. acidophilus as probiotic on protein profile and immune parameters of skin mucus as well as ghrelin gene expression of gold fish (Carassius auratus gibelio). Dietary probiotic affected protein profile and improved immune parameters. Interestingly, feeding on probiotic suppressed appetite related gene, while, immune related genes were upregulated by probiotic treatments. These studies highlighted the potential of $L b$. acidophilus as probiotic for ornamental fish.

Furthermore, in a study with Nile tilapia, Villamil et al. (2014) evaluated possible effects of $L b$. acidophilus on the expression of immune related genes as well as resistance against $A$. hydrophila. The results showed up-regulation of IL- $1 \beta$ and transferrin in spleen and kidney. Also, feeding on probiotic supplemented diet resulted in higher protection against disease. Furthermore, the author reported that extracellular products (ECPs) of $L b$. acidophilus inhibited the growth of different fish pathogens under in vitro conditions. He et al. (2017) carried out a study on hybrid grouper (Epinephelus lanceolatus $\sigma^{7} \times$ Epinephelus fuscoguttatus o) fed either single $L b$. acidophilus LAG01 or in combination with B. cereus BC-01, Clostridium butyricum CBG01 for 60 days. Feeding on either $L b$. acidophilus or combination of three strains remarkably increased growth performance. Similar results were observed in case of digestive- and antioxidant enzymes activities. However, no statistical significant difference were revealed between mono or multi-strain probiotic supplementation.

\section{Lactobacillus casei}

In a 60-days feeding trial with shirbot (Barbus gryprus) fed four experimental diets with varying dose $\left(5 \times 10^{6}, 5 \times 10^{7}\right.$, and $5 \times 10^{8} \mathrm{CFU} \mathrm{g}^{-1}$ ) of $\mathrm{Lb}$. casei, the results revealed higher performance in probiotic fed fish (Mohammadian et al., 2017). Furthermore, chymotrypsin and trypsin activities in probiotic groups were remarkably higher compared to the control. Safari et al. (2017) showed beneficial effects of $L b$. casei on innate immune parameters (either serum or skin mucus) as well as expression of selected immune and antioxidant defense related genes. Moreover, the authors revealed that combined administration of probiotic with apple cider vinegar improved efficacy of the probiotic supplementation. This study highlighted the importance of additional research on evaluation of other feed additives (e.g., medicinal herbs and prebiotics) to be used in combination with probiotics, a topic being less investigated in fish (Ringø and Song, 2016).

Zebrafish (Danio rerio) has been suggested as model organism in human and animal studies (Penberthy et al., 2002; Hoseinifar et al., 2017). The possible effects of $L b$. casei as probiotic on reproductive performance and maternal immunity of zebra fish 
was studied by Qin et al. (2014). Zebrafish fed the probiotic diet for 28 days displayed remarkably improved reproductive parameters such as egg ovulation, fertilization, and hatching rate. Furthermore, feeding on probiotic noticeably increased the expression of selected genes related to reproduction (eptin, kiss2, gnrh3, fsh, lh, lhcgr, and paqr8).

\section{Lactobacillus paracasei}

In a study using rainbow trout $(31.25 \pm 3.43 \mathrm{~g})$, Lopez Cazorla et al. (2015) tested Lb. paracasei subsp. tolerans F2 as probiotic on growth performance and intestinal microbiota. This probiotic was originally isolated from the digestive tract of Ramnogaster arcuate (Osteichthyes, Clupeidae). The results revealed significant effects on growth performance parameters and $\mathrm{LAB}$ dose in intestinal microbiota of probiotic fed fish was significantly higher vs. control.

\section{Lactobacillus delbrueckii}

The effects of dietary Lb. delbrueckii $\left(1 \times 10^{5}, 1 \times 10^{6}, 1\right.$ $\times 10^{7}$, and $1 \times 10^{8} \mathrm{CFU} \mathrm{\textrm {g } ^ { - 1 }}$ ) on immune parameters as well as protection against $A$. hydrophila in carp was studied by Zhang C.-N. et al. (2017) and revealed improved intestinal immune parameters. Furthermore, probiotic feeding affected immune related genes expression; down-regulation of TNF- $\alpha$, $I L$ 8, IL- $1 \beta$, and NF- $\kappa B p 65$ and up-regulation of $I L-10$ and TGF- $\beta$ genes. Moreover, fish fed with $1 \times 10^{6} \mathrm{CFU} \mathrm{g}^{-1} \mathrm{Lb}$. delbrueckii showed increased antioxidant defense both at gene expression and enzyme levels. The challenge test showed higher protection against A. hydrophila infection. Mohammadian et al. (2016) used a Lb. delbrueckii ssp. bulgaricus isolated from shirbot intestine and supplemented the diet with the probiotic at rate of $5 \times$ $10^{7} \mathrm{CFU} \mathrm{g} \mathrm{g}^{-1}$. At the end of feeding trial, 60 days, immune parameters as well as resistance against A. hydrophila were measured. Evaluation of immune response and disease resistance revealed higher immune parameters (lysozyme, complement, and respiratory burst activities) as well as survival rate after challenge test (Mohammadian et al., 2016).

\section{Lactobacillus rhamnosus}

In a study using European eel (Anguilla anguilla), Vílchez et al. (2015) administered three dose $\left(10^{3}, 10^{5}\right.$, and $\left.10^{6} \mathrm{CFU} / \mathrm{g}\right)$ of $L b$. rhamnosus in the diet and monitored possible effects on spermatogenesis process. After 63 days of oral administration, up-regulation of genes related to reproduction such as activin, androgen receptors $\alpha$ and $\beta$ ( $\operatorname{ar} \alpha$ and $\operatorname{ar} \beta$ ), progesterone receptor 1 (pr1), bone morphogenetic protein 15 (bmp15), and FSH receptor $(f s h r)$ was noticed. These changes at molecular levels were corresponded with observed changes in sperm quality and quantity. The authors concluded that $L b$. rhamnosus confers the spermatogenesis process in European eel. Dawood et al. (2016b) also conducted an investigation on the effects of $L b$. rhamnosus (either single e or combined with $L b$. lactis) on growth performance and immune parameters of red sea bream, and displayed increased immune parameters and antioxidant defense in fish fed supplemented diet; higher effect was revealed when the two strains was used simultaneously. Similar effects were observed on growth performance and feed utilization.
Moreover, probiotic administration decreased total cholesterol and triglycerides levels. The same research group, evaluated in another study the effects of varying dose $\left(1 \times 10^{2}, 1 \times 10^{4}\right.$, and $1 \times 10^{6}$ cells $\mathrm{g}^{-1}$ ) of Lb. rhamnosus on red sea bream (Dawood et al., 2017), showed significant increase of plasma and mucus parameters (total protein, mucus myeloperoxidase activity, and mucus secretion), and concluded the results to be a sign for beneficial effects on host physiological responses. In a study with rainbow trout, Popovic et al. (2017) investigated the effect of dietary Lb. rhamnosus $\left(10^{7}\right.$ and $\left.10^{8} \mathrm{CFU} \mathrm{g}^{-1}\right)$ on intestinal microbiota and histology, biochemical parameters, and antioxidant defense in a 6-weeks feeding trial. While probiotic feeding had no significant effects on antioxidant defense, biochemical parameters were affected. Moreover, histological investigations revealed improvement of microvilli length in the proximal intestine (PI) as well as enhanced number of goblet cells in PI and distal intestine of probiotic fed fish. The authors concluded that $L b$. rhamnosus was a promising feed additive, capable of improving rainbow trout health (Popovic et al., 2017).

\section{Pediococcus spp.}

\section{Pediococcus acidilactici}

During the past years there was increasing interests toward administration of Pediococcus spp. as probiotic in aquaculture and most of the studies have focused on $P$. acidilactici; the commercial product named Bactocell. For instance, the possible effects of dietary $P$. acidilactici $\left(10^{6} \mathrm{CFU} / \mathrm{g}\right)$ was assessed on sperm quality in zebrafish (Valcarce et al., 2015). After 10 days treatment of zebrafish male with probiotic, remarkable up-regulation of selected genes related to male and sperm quality was noticed. Hoseinifar et al. (2015a,b, 2016b) studied the effects of single or combined administration of $P$. acidilactici and galactooligosaccharide in rainbow trout. While single administration had no significant effects on growth performance, combined administration remarkably improved growth performance parameters. Also, feeding on supplemented diet remarkably increased immune response and resistance against Streptococcus iniae. Similar results were observed in a study using common carp (Modanloo et al., 2017). Furthermore, in a study with ornamental fish, green terror (Aequidens rivulatus), Neissi et al. (2013) studied the effects $0.1 \%$ inclusion of commercial $P$. acidilactici and revealed remarkable increase of the innate immune parameters as well as improvement of stress indicators following exposing fish to hypoxia stress.

\section{Pediococcus pentosaceus}

Recently, Pediococcus pentosaceus has received attention as probiotic, but still limited information on the use of this strain is available. In a 56 days study, the effects of different dose $\left(1.6 \times 10^{10}, 1.6 \times 10^{11}, 1.6 \times 10^{12}\right.$, and $3.2 \times 10^{12}$ cells $\mathrm{g}^{-1}$ ) of inactivated $P$. pentosaceus was evaluated in red sea bream (Dawood et al., 2016a). Dietary administration of inactivated probiotic noticeably increased growth performance as well as mucus secretion. Also, skin mucus and serum immune parameters showed increment following treatment with probiotic. Furthermore, fish fed the probiotic supplemented diets had remarkably higher low-salinity stress resistance. Based 
on these results the authors suggested that inactivated $P$. pentosaceus as efficient and safe probiotic. Likewise, Moslehi et al. (2016) reported modulation of intestinal microbiota as well as body composition in Siberian sturgeon following dietary administration of a $P$. pentosaceus strain isolated from Persian sturgeon intestine. Furthermore, Huang J.-B. et al. (2014) addressed the effect of $P$. pentosaceus as probiotic in orangespotted grouper (Epinephelus coioides). The probiotic bacteria was originally isolated by the authors from cobia (Rachycentron canadum) intestine. The strain showed antagonistic effects against pathogens under in vitro conditions and in an in vivo experiment, dietary administration of $P$. pentosaceus significantly increased growth performance, immune related genes expression as well as disease resistance.

\section{Weissella spp.}

There is relatively limited information available about efficacy of Weissella species as probiotic in aquaculture. In recent study with Brazilian native surubins $(43.3 \mathrm{~g})$, the effects of dietary Weissella cibaria $\left(1.18 \times 10^{7} \mathrm{CFU} \mathrm{g}^{-1}\right)$ was investigated on performance, haemato-immunological parameters and intestinal histomorphology (Jesus et al., 2017). Regarding the hematological parameters, most of the parameters remained unaffected, except red blood cells, thrombocyte and lymphocyte counts which were higher in probiotic fed fish. Evaluation of immune parameters revealed higher phagocytosis, agglutination titer, and total Ig in probiotic groups compared with control. Feeding on probiotic supplemented diets significantly improved intestinal histology as observed increased height and width and number of villi as well as mucus producing goblet cells counts per villi. These results highlighted the potential of Weissella spp. to be used as a novel probiotic in aquaculture.

\section{Leuconostoc spp.}

To our knowledge, possible effects of Leuconostoc as probiotic has only been investigated in one study. Allameh et al. (2016) supplemented Javanese carp (Puntius gonionotus) diet with either single $L c$. mesenteroides or in combination with E. faecalis and Lb. fermentum as multi-strains probiotics. Interestingly, growth performance of fish fed single Lc. mesenteroides was better than those fed multi-strains probiotic. However, no significant effect was noticed in body composition.

\section{Lactococcus spp.}

Nguyen et al. (2017) isolated L. lactis WFLU12 from intestine of wild marine fishes and based on in vitro probiotic effects selected the strain to be used in olive flounder diet. Interestingly, inclusion of this host-associated probiotic caused improvement of immune responses and protection against Streptococcus parauberis infection. Besides, probiotic fed fish showed improved growth performance and feed utilization. These results highlighted the importance of isolation of host-associated probiotic, a topic that merits further investigations.

\section{Enterococcus spp.}

Enterococcus spp. and especially E. faecium are among the most studied probiotics in aquaculture, and from 2014 there are some reports available. For instance, Allameh et al. (2015) studied possible effect of oral administration of E. faecium on physiological responses of Javanese carp. Fish were fed on a single dose $\left(10^{7} \mathrm{CFU} / \mathrm{g}\right)$ for 5 weeks and at the end of the rearing period; significant increase of digestive enzymes activity as well as intestinal short chain fatty acid production (propionic and butyric acid) were noticed in the probiotic group. These improvements were in line with increased protection against $A$. hydrophila challenge. In accordance, elevation of cell-mediated immune response following oral administration of E. faecium has been reported by Matsuura et al. (2017). Besides the results on E. faecium, there are interests toward other species of this genus. Enterococcus gallinarum L-1 was used as potential probiotic in different species including gilthead sea bream, European sea bass, meager (Argyrosomus regius) and red porgy (Pagrus pagrus) diets (Román et al., 2015). The strain was originally isolated from gilthead sea bream intestine and the authors tested different forms; live or inactivated with heat or U.V. The authors reported no immunostimulatory effects of E. gallinarum in meager, however, immune stimulation was noticed in sea bream, sea bass and red porgy leucocytes. The immunostimulatory effects were increased along with elevation of probiotic level in diet; highest dose in the $10^{8} \mathrm{CFU} \mathrm{mL}-1$ treatment. Furthermore, Safari et al. (2016) isolated Enterococcus casseliflavus from rainbow trout intestine and evaluated its probiotic potential in rainbow trout. The probiotic strain was orally administered at rate of $10^{7}, 10^{8}$, and $10^{9} \mathrm{CFU} \mathrm{\textrm {g } ^ { - 1 }}$ for 8 weeks. At the end of feeding trial, significant change was noticed in LAB counts in the intestinal microbiota. This change was in line with remarkably increase of humoral immune parameters. Also, probiotic fed fish had significantly higher resistance when exposed to experimental challenge with S. iniae. Based on these results the authors suggested this host-associated strain as beneficial probiotic for rainbow trout culture.

When discussing the use of probiotics, it is of interest to notice that Lb. rhamnosus GG outcompete vancomycinresistant E. faecium via mucus-binding pili (Tytgat et al., 2016), and the finding of $\mathrm{He}$ et al. (2017) using $L b$. rhamnosus GG and its mutant (PB22) lacking SpaCBA pili to investigate the influence of pili on spatial distribution. LGG showed a mucosa type distribution, while PB22 revealed a hybrid distribution and the disease protection was accordingly improved.

However, prior to use of probiotics; injury to the mucosa and epithelial cells should be investigated in details as $L b$. plantarum originally isolated from traditional Sabalan Iranian cheese from sheep raw milk resulted in damaged epithelial cells and disorganized microvilli of beluga (Huso huso) (Salma et al., 2011), while LGG induced injury to the mucosa of zebrafish ( $\mathrm{He}$ et al., 2017).

\section{PATHOGENIC LAB}

In addition to probiotic, some pathogenic LAB are also documented (Ringø and Gatesoupe, 1998; Leisner et al., 2007; 
TABLE 5 | Pathogenic LAB in aquaculture.

\begin{tabular}{|c|c|c|}
\hline $\begin{array}{l}\text { Pathogenic LAB } \\
\text { species }\end{array}$ & Studied species & References \\
\hline S. agalactiae & $\begin{array}{l}\text { Silver pomfret (Pampus argenteus) } \\
\text { Red tilapia (Oreochromis niloticus) } \\
\text { Golden pompano (Trachinotus blochii) } \\
\text { Barcoo grunter (Scortum barcoo) } \\
\text { Hybrid tilapia (O. niloticus } \times \text { O. aureus) }\end{array}$ & $\begin{array}{l}\text { Duremdez et al., } 2004 \\
\text { Musa et al., } 2009 \\
\text { Amal et al., } 2012 \\
\text { Liu et al., } 2014 \\
\text { Al-Harbi, } 2016\end{array}$ \\
\hline $\begin{array}{l}\text { S. dysgalactiae } \\
\text { S. parauberis } \\
\text { S. uberis }\end{array}$ & $\begin{array}{l}\text { Sturgeon (Acipenser schrenckii) } \\
\text { Wild striped bass (Morone saxatilis) } \\
\text { Mandarin fish (Siniperca chuatsi) }\end{array}$ & $\begin{array}{l}\text { Yang and Li, } 2009 \\
\text { Haines et al., } 2013 \\
\text { Luo et al., } 2017\end{array}$ \\
\hline \multirow[t]{5}{*}{ L. garvieae } & Red sea wrasse (Coris aygula) & Colorni et al., 2003 \\
\hline & $\begin{array}{l}\text { Nile tilapia and Pintado (Pseudoplathystoma corruscans) } \\
\text { Rainbow trout (Oncorhynchus mykiss) }\end{array}$ & $\begin{array}{l}\text { Evans et al., } 2009 \\
\text { Aguado-Urda et al., 2011; Reimundo } \\
\text { et al., } 2011\end{array}$ \\
\hline & Gray mullet (Mugil cephalus) & Chen et al., 2002 \\
\hline & Catfish (Silurus glanis) & Ravelo et al., 2003 \\
\hline & Freshwater prawn (Macrobrachium rosenbergii) & Shih-Chu et al., 2001 \\
\hline
\end{tabular}

Michel et al., 2007). This sub-chapter focus on pathogenic LAB in aquaculture (Table 5), and the treatments (Table 6).

\section{Streptococcus}

Streptococcus spp. is the most common pathogen in aquaculture, and up to date, several species within this genus have been reported as important pathogens of fish, such as silver pomfret (Pampus argenteus) (Duremdez et al., 2004), red tilapia (O. niloticus) (Musa et al., 2009), golden pompano (Trachinotus blochii) (Amal et al., 2012), barcoo grunter (Scortum barcoo) (Liu et al., 2014), and hybrid tilapia (O. niloticus $\times$ O. aureus) (Al-Harbi, 2016).

Infection of Streptococcus agalactiae led to persistent high mortality with a distinctive swollen belly, eye hemorrhages, corneal opacity, exophthalmia, hemorrhage, enlarged liver and congestion of the kidney and spleen (Duremdez et al., 2004; Amal et al., 2012; Liu et al., 2014; Al-Harbi, 2016). To deal with this bacterial strain, several type of vaccines have been developed, which include formalin-killed cells and concentrated extracellular products of a single isolate of $S$. agalactiae vaccine
(Evans et al., 2004), feed-based recombinant vaccine encoding cell wall surface anchor family protein of $S$. agalactiae (NurNazifah et al., 2014), oral DNA vaccine (Huang L. Y. et al., 2014; Ma et al., 2017; Zhu et al., 2017), FbsA and $\alpha$-enolase (Yi et al., 2014), SA $\Delta$ phoB live attenuated vaccine (Cai et al., 2017), PLGA-LrrG protein micro-particle vaccine (Ke et al., 2017), and GapA protein vaccine (Zhang Z. et al., 2017). In addition to vaccines, many functional feed additives have been proved to protect fish and shellfish against $S$. agalactiae such as $\mathrm{Ku}$ shen (Sophora flavescens) root extract (Wu et al., 2013), liposomeencapsulated cinnamaldehyde (Faikoh et al., 2014), B. subtilis and B. pumilus Ng et al., 2014; Liu H. et al., 2017; Srisapoome and Areechon, 2017, yeast (Saccharomyces cerevisiae) (Pinpimai et al., 2015), Lb. rhamnosus (Pirarat et al., 2015), essential oils (Brum et al., 2017), buta-buta (Excoecaria agallocha) leaf extracts (Laith et al., 2017), $\beta$-glucan (Pilarski et al., 2017), kefir, low molecular weight sodium alginate, and $L b$. plantarum Van Doan et al., 2016a,b, 2017b, and scarlet caterpillar (Cordyceps militaris) spent mushroom substrate and Lb. plantarum (Doan et al., 2017; Van Doan et al., 2017a). S. iniae is another Streptococcus species 
TABLE 6 | Treatments for pathogenic $L A B$ in aquaculture.

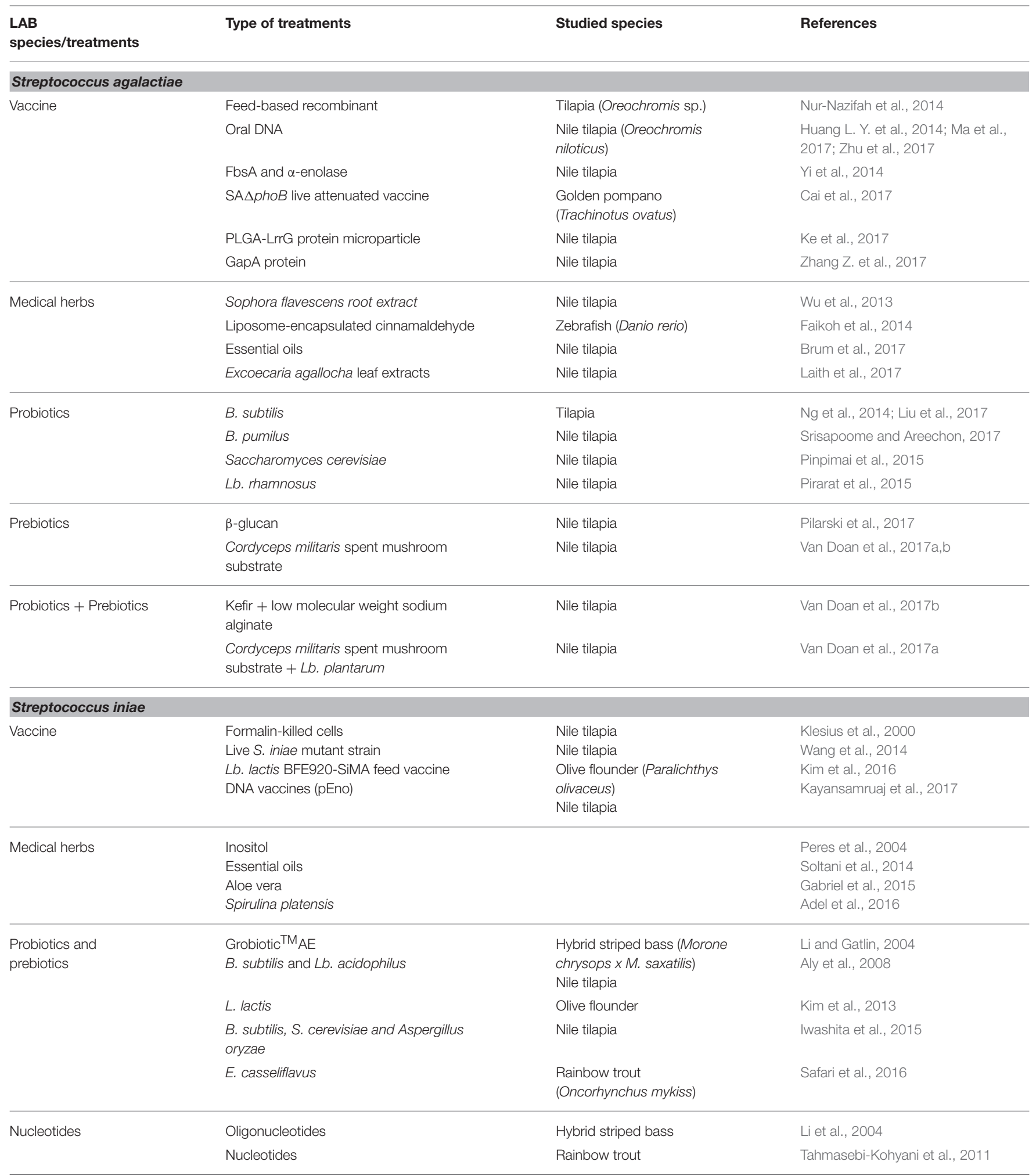


TABLE 6 | Continued

\begin{tabular}{llll}
\hline $\begin{array}{l}\text { LAB } \\
\text { species/treatments }\end{array}$ & Type of treatments & Studied species & References \\
\hline Vitamins & Vitamin E & & Nile tilapia \\
& Vitamin A & Nile tilapia et al., 2009 \\
S. dysgalactiae & Not available & Not available & Guimarães et al., 2014 \\
$\begin{array}{l}\text { S. parauberis } \\
\text { S. uberis }\end{array}$ & & Not available
\end{tabular}

\section{Enterococcus faecalis}

Medical plants

Tamarindus indica and Emblica officinalis leaves, Allium sativum bulb, and Syzygium

Nile tilapia, freshwater

Rahman et al., 2017 aromaticum bud extracts

catfish (Clarias batrachus)

and Asian stinging catfish

(Heteropneustes fossilis)

\begin{tabular}{|c|c|c|c|}
\hline \multicolumn{4}{|c|}{ Lactococcus garvieae } \\
\hline Vaccine & $\begin{array}{l}\text { Autogenous formalin-inactivated } \\
\text { Inactivated vaccine Ichtiovac-Lg } \\
\text { Bivalent vaccine } \\
\text { Subunit vaccines }\end{array}$ & $\begin{array}{l}\text { Tilapia and rainbow trout } \\
\text { Rainbow trout } \\
\text { Rainbow trout and } \\
\text { Olive flounder }\end{array}$ & $\begin{array}{l}\text { Bercovier et al., } 1997 \\
\text { Vendrell et al., } 2007 \\
\text { Bastardo et al., } 2012 \\
\text { Ra et al., } 2009\end{array}$ \\
\hline Medical herbs & $\begin{array}{l}\text { Essential oils } \\
\text { Mushroom extracts } \\
\text { Stinging nettle } \\
\text { Extract of noni leaves } \\
\text { Huanglian Jiedu decoction }\end{array}$ & $\begin{array}{l}\text { Rainbow trout } \\
\text { Rainbow trout } \\
\text { Rainbow trout } \\
\text { Freshwater prawn } \\
\text { (Macrobrachium } \\
\text { rosenbergii) } \\
\text { Gray mullet (Mugil cephalus) }\end{array}$ & $\begin{array}{l}\text { Soltani et al., } 2015 \\
\text { Baba et al., } 2015 \\
\text { Saeidi Asl et al., } 2017 \\
\text { Marisa Halim et al., } 2017 \\
\text { Choi et al., } 2014\end{array}$ \\
\hline Antibiotics & $\begin{array}{l}\text { Lincomycin, tetracycline chloramphenicol } \\
\text { Erythromycin, lincomycin, and } \\
\text { oxytetracycline } \\
\text { Erythromycin, oxytetracycline, and } \\
\text { amoxicillin }\end{array}$ & $\begin{array}{l}\text { Yellow tail (Seriola } \\
\text { quinqueradiata) } \\
\text { Yellow tail }\end{array}$ & $\begin{array}{l}\text { Aoki et al., } 1990 \\
\text { Kawanishi et al., } 2005 \\
\text { Vendrell et al., } 2006\end{array}$ \\
\hline
\end{tabular}

that cause disease outbreaks in different fish species (Agnew and Barnes, 2007), hybrid striped bass (Morone chrysops $\times$ Morone saxatilis) (Stoffregen et al., 1996), rabbitfish (Siganus canaliculatus) (Yuasa et al., 1999), European sea bass (Colorni et al., 2002), Japanese flounder (Nguyen et al., 2002), barramundi (L. calcarifer) (Bromage et al., 1999), and hybrid tilapia (AlHarbi, 2011). Infection of this bacterium has led to vast economic losses in the world aquaculture industry of $\sim 150$ million US\$, annually (Shoemaker et al., 2001; Al-Harbi, 2011). Huge effort has been contributed to deal with this bacterium which include vaccine (Klesius et al., 2000; Wang et al., 2014; Kim et al., 2016; Kayansamruaj et al., 2017), probiotics (B. subtilis, Lb. acidophilus, L. lactic, E. casseliflavus, S. cerevisiae, and Aspergillus oryzae) and prebiotics (Grobiotic ${ }^{\mathrm{TM}} \mathrm{AE}$ ) (Li and Gatlin, 2004; Aly et al., 2008; Kim et al., 2013; Iwashita et al., 2015; Safari et al., 2016), medicinal plants (inositol, essential oil, Aloe vera, and Spirulina platensis) (Peres et al., 2004; Soltani et al., 2014; Gabriel et al., 2015; Adel et al., 2016), nucleotides (Li et al., 2004; Tahmasebi-Kohyani et al., 2011), and vitamins(A and E) (Lim et al., 2009; Guimarães et al., 2014). Besides these two common pathogens, several species within genus Streptococcus such as
Streptococcus dysgalactiae (Yang and Li, 2009), S. parauberis (Haines et al., 2013), and Streptococcus uberis (Luo et al., 2017) have been reported to be pathogenic in aquaculture. However, to our knowledge, there is no treatment against these species.

\section{Enterococcus}

Enterococcus sp. is an important pathogen in aquaculture, with severely impacts in commercial aquaculture practices worldwide (Martins et al., 2008; Rahman et al., 2017). The first report on the occurrence of pathogenic Enterococcus sp. in fish was revealed in yellow tail (Seriola quinqueradiata) in Japan (Kusuda and Salati, 1993). Later, Enterococcus was revealed in turbot (S. maximus) (Nieto et al., 1995), and tilapia (O. niloticus) (Plumb and Hanson, 2010). E. faecalis has been reported as causative agent of streptococcal infection in tilapia in lakes of Egypt, Thailand, and Bangladesh (Petersen and Dalsgaard, 2003; Abou El-Geit et al., 2013; Rahman et al., 2017). To our knowledge, limited information regarding prevention and treatment methods against E. faecalis has been reported. However, recently, Rahman et al. (2017) demonstrated 
that extraction of some medicinal plants, such as tamarind (Tamarinds indica), Indian gooseberry (Phyllanthus emblica), garlic (Allium sativum), and clove (Syzygium aromaticum) significantly protected fish against $E$. faecalis infection.

\section{Lactococcus garvieae}

The pathogenicity of L. garvieae is well-known (Vendrell et al., 2006; Michel et al., 2007; Fukushima et al., 2017; Meyburgh et al., 2017) and the bacterium is the causative agent of lactococcosis, a hyperacute haemorrhagic septicaemia of fish. Huge economic loss in several economical freshwater - and marine fish species has been reported as a result of lactococcosis infection in Red sea wrasse (Coris aygula) (Colorni et al., 2003), Nile tilapia and pintado (Pseudoplathystoma corruscans) (Evans et al., 2009), rainbow trout (Aguado-Urda et al., 2011; Reimundo et al., 2011), gray mullet (Mugil cephalus) (Chen et al., 2002), catfish (Silurus glanis) (Ravelo et al., 2003), and freshwater prawn (Macrobrachium rosenbergii) (Shih-Chu et al., 2001). The common way to deal with this bacterium was the use of antibiotic, such as lincomycin, oxytetracycline and macrolides (Aoki et al., 1990; Kawanishi et al., 2005), and erythromycin, oxytetracycline, amoxicillin, and doxycycline have been widely used to control outbreaks of lactococcosis through rainbow trout (Vendrell et al., 2006). It is known that antibiotics were highly effective against $L$. garvieae in in vitro studies, but not in field conditions because of anorexia of infected fish (Bercovier et al., 1997) and possibly by ineffective metabolism of antibiotics in fish (Meyburgh et al., 2017). Due to this limitation of antibiotics and their sideeffects in aquaculture practice, vaccination was considered as most effective to control lactococcosis (Meyburgh et al., 2017). Several types of vaccine have been developed such as autogenous formalin-inactivated vaccines (Bercovier et al., 1997), inactivated vaccine Ichtiovac-Lg (Vendrell et al., 2007), bivalent vaccine (Bastardo et al., 2012), and subunit vaccines (Ra et al., 2009). In addition to vaccines, several functional feed additives have been demonstrated to protect the fish against this bacterium which include essential oil (Soltani et al., 2015), mushroom extracts (Baba et al., 2015), stinging nettle (Saeidi Asl et al., 2017), extract of noni leaves (Marisa Halim et al., 2017), and Huanglian Jiedu decoction (Choi et al., 2014).

\section{Carnobacterium}

C. maltaromaticum was reported as an important species and is reported in numerous fish species and meat products (Leisner et al., 2012). This bacterium has been demonstrated as a promising probiotic for aquaculture (Ringø et al., 2005; Kim and Austin, 2008; Pikuta and Hoover, 2014). However, some strains of this bacterium has been reported as fish pathogens with low virulence and stressed fish are especially susceptible, particularly post spawning (Michel et al., 1986; Starliper et al., 1992). Several fish species has been infected with C. maltaromaticum such as rainbow trout (Hiu et al., 1984; Baya et al., 1991; Starliper et al., 1992; Toranzo et al., 1993b), striped bass and channel catfish (Baya et al., 1991; Toranzo et al., 1993a), salmon (Hiu et al., 1984; Michel et al., 1986), and lake whitefish (Loch et al., 2008). However, to our knowledge, there is no information available regarding prevention and treatment approaches of this bacterium in aquaculture.

\section{PRACTICAL USES OF LAB AS AN IMMUNOSTIMULANT IN FINFISH AQUACULTURE}

Finfish share many common structures and functions with warm-blooded animals in innate immunity (Whyte, 2007), adaptive immunity (Laing and Hansen, 2011), and mucosal immunity (Gomez et al., 2013), although apparent differences exist. The finfish immune systems are regulated in the same or very similar manners to those of other vertebrates. Since antibiotics have significant limitations in finfish aquaculture, the field has sought safer and more effective antibiotic alternatives. Natually, LAB became a candidate for a substitute for antibiotics because the immunostimulant effects of LAB have been well established in other animals including human.

Various strains of LAB have been studied in their immune modulatory effects on many different finfish species; summarized in Tables 7, 8. Genus Lactobacillus is most studied (Salinas et al., 2006; Balcázar et al., 2007b; Picchietti et al., 2009; Harikrishnan et al., 2011; Biswas et al., 2013; Giri et al., 2013; Liu et al., 2013; Gioacchini et al., 2014; Van Doan et al., 2014, 2016a,b; Beck et al., 2015, 2016; Mohammadian et al., 2016; Lee et al., 2017; Zhang Z. et al., 2017). The second most investigated genus is Lactococcus (Balcázar et al., 2007b; Kim et al., 2013; Beck et al., 2015, 2016; Nguyen et al., 2017). Genera of Enterococcus, Pediococcus, and Leuconostoc have also been studied at a significant level; Enterococcus (Wang et al., 2008; Kim et al., 2012; RodriguezEstrada et al., 2013; Matsuura et al., 2017), Pediococcus (Neissi et al., 2013; Dawood et al., 2016a; Kaew-on et al., 2016), Leuconostoc (Balcázar et al., 2007b). Although the majority of the studies used a specific strain of live LAB (Table 7), some studies were performed with their inactivated form of LAB (Table 8). The immunostimulant effects of a mixture of two different $\mathrm{LAB}$ were also investigated. These studies revealed that the mixture $\mathrm{LAB}$ were superior to a single homogenous LAB in the probiotic effects (Beck et al., 2015; Maji et al., 2017). Not only various strains of LAB, but diverse species of subject fish were investigated as well; olive flounder, Nile tilapia, shirbot, Huanghe common carp (C. carpio Huanghe var.), European sea bass; basa fish (P. bocourti), Japanese eel (Anguilla japonica), rohu, zebrafish, striped beakfish (Oplegnathus fasciatus), rainbow trout, green terror (A. rivulatus), goldfish (Carassius auratus), gilthead sea bream, tiger puffer (Takifugu rubripes) and red sea bream.

The mode of administration of $\mathrm{LAB}$ is an important factor for practical use of LAB in the field. Feeding the LAB adsorbed into regular diets may be the best way for administration because this feeding method reduces labor and stress to fish. As expected, a vast majority of studies employed dietary $L A B$ as the mode of administration. However, some studies treated the fish by intraperitoneal injection (Kim et al., 2012; Matsuura et al., 2017) or immersion in a LAB-containing bath (Wang et al., 2008). Many studies indicated that the feeding administration 
TABLE 7 | Immunological changes of finfish resulted by live LAB treatment.

\begin{tabular}{|c|c|c|c|c|c|}
\hline LAB & Fish model (weight) & $\begin{array}{l}\text { Administration route } \\
\text { and dose }\end{array}$ & $\begin{array}{l}\text { Administration } \\
\text { length }\end{array}$ & Immunological changes & References \\
\hline $\begin{array}{l}\text { E. faecium (strain } \\
\text { not mentioned) }\end{array}$ & $\begin{array}{l}\text { Olive flounder } \\
\text { (Paralichthys olivaceus) } \\
(33.4 \pm 10 \mathrm{~g})\end{array}$ & $\begin{array}{l}\text { Intraperitoneal injection } \\
10^{9} \mathrm{CFU} / \text { fish }\end{array}$ & 15 days & $\begin{array}{l}\text { Alternative complement activity } \uparrow \text {, } \\
\text { Serum lysozyme activity } \uparrow \text {, } \\
\text { Spleen: IL- } 1 \beta \uparrow, \\
\text { Kidney: } I L-1 \beta \uparrow, T N F-\alpha \uparrow\end{array}$ & Kim et al., 2012 \\
\hline E. faecium ZJ4 & $\begin{array}{l}\text { Nile tilapia (Oreochromis } \\
\text { niloticus) (6.834 } \pm 0.18 \mathrm{~g})\end{array}$ & $\begin{array}{l}\text { Immersion } \\
10^{7} \mathrm{CFU} / \mathrm{mL} \\
\text { supplemented in } \\
\text { aquaria for every } 4 \text { days }\end{array}$ & 40 days & $\begin{array}{l}\text { Complement C3 } \uparrow \text {, } \\
\text { Myeloperoxidase activity } \uparrow \text {, } \\
\text { NBT reaction (respiratory burst) } \uparrow, \\
\text { Serum lysozyme activity } \uparrow,\end{array}$ & Wang et al., 2008 \\
\hline $\begin{array}{l}\text { Lb. acidophilus } \\
\text { JCM } 1132\end{array}$ & $\begin{array}{l}\text { Nile tilapia (Oreochromis } \\
\text { niloticus o } \times \text { Oreochromis } \\
\left.\text { aureus } \sigma^{\top}\right)(0.9 \mathrm{~g})\end{array}$ & $\begin{array}{l}\text { Diet } \\
10^{5}, 10^{7}, 10^{9} \mathrm{CFU} / \mathrm{g} \\
\text { feed }\end{array}$ & $\begin{array}{l}10,20,35 \\
\text { days } \\
\text { (consecutive) }\end{array}$ & $\begin{array}{l}\text { Spleen: IL- } 1 \beta \uparrow, T G F-\beta \uparrow, T N F-\alpha \uparrow \text { at day } \\
20, T N F-\alpha \downarrow \text { at day } 35 \\
\text { Kidney: IL- } 1 \beta \uparrow \text { at day } 20, I L-1 \beta \downarrow \text { at day } \\
35, \\
\text { TGF- } \beta \uparrow, T G F-\beta \downarrow \text { at day } 35 \text { in } 10^{5} \text { CFU/g } \\
\text { feed, TNF- } \alpha \uparrow \\
\text { Protection against } A \text {. hydrophila } \uparrow \\
\text { * Increased or decreased gene } \\
\text { expressions were varied by dose and } \\
\text { sample collection time mark. }\end{array}$ & Liu et al., 2013 \\
\hline $\begin{array}{l}\text { Lb. brevis JCM } \\
1170\end{array}$ & Nile tilapia (0.9 g) & $\begin{array}{l}\text { Diet } \\
10^{5}, 10^{7}, 10^{9} \mathrm{CFU} / \mathrm{g} \\
\text { feed }\end{array}$ & $\begin{array}{l}10,20,35 \\
\text { days } \\
\text { (consecutive) }\end{array}$ & $\begin{array}{l}\text { Spleen: } I L-1 \beta \uparrow, T G F-\beta \uparrow \text { at day } 20 \text {, } \\
T G F-\beta \downarrow \text { at day } 35, T N F-\alpha \uparrow \text { at day } 20, \\
T N F-\alpha \downarrow \text { at day } 35 \\
\text { Kidney: } I L-1 \beta \uparrow \text { at day } 20, I L-1 \beta \downarrow \text { at day } \\
35, T G F-\beta \uparrow \text { at day } 20, T N F-\alpha \uparrow \text { at day } 35 \\
\text { Protection against } A \text {. hydrophila } \uparrow \\
\text { * Increased or decreased gene } \\
\text { expressions were varied by dose and } \\
\text { sample collection time mark. }\end{array}$ & Liu et al., 2013 \\
\hline $\begin{array}{l}\text { Lb. casei } \\
\text { PTCC1608 }\end{array}$ & $\begin{array}{l}\text { Shirbot (Barbus grypus) } \\
\text { (50 g) }\end{array}$ & $\begin{array}{l}\text { Diet } \\
5 \times 10^{7} \mathrm{CFU} / \mathrm{g} \text { feed }\end{array}$ & 6 weeks & $\begin{array}{l}\text { Alternative complement activity } \uparrow, \\
\text { NBT reaction (respiratory burst) } \uparrow, \\
\text { Protection against } A \text {. hydrophila } \uparrow\end{array}$ & $\begin{array}{l}\text { Mohammadian } \\
\text { et al., } 2016\end{array}$ \\
\hline $\begin{array}{l}\text { Lb. delbrueckii } \\
\text { ssp. bulgaricus } \\
\text { (original isolate by } \\
\text { authors) }\end{array}$ & Shirbot (50 g) & $\begin{array}{l}\text { Diet } \\
5 \times 10^{7} \mathrm{CFU} / \mathrm{g} \text { feed }\end{array}$ & 6 weeks & $\begin{array}{l}\text { Alternative complement activity } \uparrow \text {, } \\
\text { NBT reaction (respiratory burst) } \uparrow \text {, } \\
\text { Protection against } A \text {. hydrophila } \uparrow\end{array}$ & $\begin{array}{l}\text { Mohammadian } \\
\text { et al., } 2016\end{array}$ \\
\hline $\begin{array}{l}\text { Lb. plantarum } \\
\text { (original isolate by } \\
\text { authors) }\end{array}$ & Shirbot (50 g) & $\begin{array}{l}\text { Diet } \\
5 \times 10^{7} \mathrm{CFU} / \mathrm{g} \text { feed }\end{array}$ & 6 weeks & $\begin{array}{l}\text { Alternative complement activity } \uparrow \text {, } \\
\text { NBT reaction (respiratory burst) } \uparrow \text {, } \\
\text { Serum lysozyme activity (only at day 60) } \uparrow \text {, } \\
\text { Protection against } A \text {. hydrophila } \uparrow\end{array}$ & $\begin{array}{l}\text { Mohammadian } \\
\text { et al., } 2016\end{array}$ \\
\hline $\begin{array}{l}\text { Lb. plantarum } \\
\text { CR1T5 }\end{array}$ & $\begin{array}{l}\text { Basa fish (Pangasius } \\
\text { bocourti) (82.01 g) }\end{array}$ & $\begin{array}{l}\text { Diet } \\
10^{8} \mathrm{CFU} / \mathrm{g} \text { feed }\end{array}$ & 4 weeks & $\begin{array}{l}\text { Alternative complement activity } \uparrow \text {, } \\
\text { Protection against } A \text {. hydrophila } \uparrow\end{array}$ & $\begin{array}{l}\text { Van Doan et al., } \\
2014\end{array}$ \\
\hline $\begin{array}{l}\text { Lb. plantarum } \\
\text { CR1T5 }\end{array}$ & Basa fish (3.57 g) & $\begin{array}{l}\text { Diet } \\
10^{8} \mathrm{CFU} / \mathrm{g} \text { feed }\end{array}$ & $\begin{array}{l}3,6,9,12 \\
\text { weeks } \\
\text { (consecutive) }\end{array}$ & $\begin{array}{l}\text { Alternative complement activity } \uparrow, \\
\text { Phagocytic activity } \uparrow, \\
\text { Serum lysozyme activity } \uparrow, \\
\text { Protection against } A \text {. hydrophila } \uparrow\end{array}$ & $\begin{array}{l}\text { Van Doan et al., } \\
2016 a\end{array}$ \\
\hline
\end{tabular}


TABLE 7 | Continued

\begin{tabular}{|c|c|c|c|c|c|}
\hline LAB & Fish model (weight) & $\begin{array}{l}\text { Administration route } \\
\text { and dose }\end{array}$ & $\begin{array}{l}\text { Administration } \\
\text { length }\end{array}$ & Immunological changes & References \\
\hline $\begin{array}{l}\text { Lb. plantarum } \\
\text { CR1T5 }\end{array}$ & $\begin{array}{l}\text { Nile tilapia } \\
(15.56 \pm 0.02 \mathrm{~g})\end{array}$ & $\begin{array}{l}\text { Diet } \\
10^{8} \mathrm{CFU} / \mathrm{g} \text { feed }\end{array}$ & $\begin{array}{l}30 \text { and } 60 \\
\text { days } \\
\text { (consecutive) }\end{array}$ & $\begin{array}{l}\text { Alternative complement activity } \uparrow, \\
\text { NBT reaction (respiratory burst) } \uparrow, \\
\text { Phagocytic activity } \uparrow, \\
\text { Serum lysozyme activity } \uparrow, \\
\text { Protection against } S \text {. agalactiae } \uparrow\end{array}$ & $\begin{array}{l}\text { Van Doan et al., } \\
2016 b\end{array}$ \\
\hline $\begin{array}{l}\text { Lb. plantarum } \\
\text { FGL0001 }\end{array}$ & $\begin{array}{l}\text { Olive flounder } \\
(42.7 \pm 1.61 \mathrm{~g})\end{array}$ & $\begin{array}{l}\text { Diet } \\
10^{7} \mathrm{CFU} / \mathrm{g} \text { feed }\end{array}$ & 4 weeks & $\begin{array}{l}\text { Intestine: CD4- } 1 \uparrow, \text { T-bet } \uparrow, \text { GATA3 } \uparrow \text {, } \\
\text { IL- } 1 \beta \uparrow, \text { IFN- } \gamma \uparrow, I L-17 A / F \downarrow \text {, } \\
\text { Gut permeability } \downarrow \text {, } \\
\text { Protection from E. tarda } \uparrow\end{array}$ & Beck et al., 2016 \\
\hline $\begin{array}{l}\text { Lb. plantarum } \\
\text { VSG3 }\end{array}$ & $\begin{array}{l}\text { Rohu } \\
(60 \mathrm{~g})\end{array}$ & $\begin{array}{l}\text { Diet } \\
10^{6}, 10^{8}, 10^{10} \mathrm{CFU} / \mathrm{g} \\
\text { feed }\end{array}$ & $\begin{array}{l}30 \text { and } 60 \\
\text { days } \\
\text { (consecutive) }\end{array}$ & $\begin{array}{l}\text { Alternative complement activity } \uparrow, \\
\text { IgM concentration at } 30^{\text {th }} \text { day }\left(10^{8} \text { and }\right. \\
10^{10} \mathrm{CFU} / \mathrm{g} \text { feed) } \uparrow \\
\text { NBT reaction (respiratory burst) } \uparrow, \\
\text { Phagocytic activity } \uparrow \\
\text { Serum lysozyme activity } \uparrow, \\
\text { Protection from } A \text {. hydrophila } \uparrow\end{array}$ & Giri et al., 2013 \\
\hline $\begin{array}{l}\text { Lb. rhamnosus } \\
\text { IMC } 501\end{array}$ & $\begin{array}{l}\text { Zebrafish (Danio rerio) } \\
\text { (adult, weight is not } \\
\text { mentioned) }\end{array}$ & $\begin{array}{l}\text { Diet } \\
10^{6} \mathrm{CFU} / \mathrm{g} \text { feed }\end{array}$ & 10 days & Liver: IL-1 $\beta \uparrow, T N F-\alpha \uparrow$ & $\begin{array}{l}\text { Gioacchini et al., } \\
2014\end{array}$ \\
\hline $\begin{array}{l}\text { Lb. sakei CLFP } \\
202\end{array}$ & Rainbow trout (40 g) & $\begin{array}{l}\text { Diet } \\
10^{6} \mathrm{CFU} / \mathrm{g} \text { feed }\end{array}$ & 2 weeks & $\begin{array}{l}\text { Alternative complement activity } \uparrow, \\
\text { Phagocytic activity } \uparrow \\
\text { Serum lysozyme activity } \uparrow, \\
\text { Protection from } A \text {. salmonicida } \uparrow\end{array}$ & $\begin{array}{l}\text { Balcázar et al., } \\
\text { 2007b }\end{array}$ \\
\hline L. lactis BFE920 & $\begin{array}{l}\text { Olive flounder } \\
(37.5 \pm 1.26 \mathrm{~g}, 40 \pm 3 \mathrm{~g} \\
55 \pm 5 \mathrm{~g})\end{array}$ & $\begin{array}{l}\text { Diet } \\
10^{7} \mathrm{CFU} / \mathrm{g} \text { feed }\end{array}$ & 4 weeks & $\begin{array}{l}\text { Myeloperoxidase activity } \uparrow, \\
\text { NBT reaction (respiratory burst) } \uparrow \text {, } \\
\text { Phagocytic activity } \uparrow \\
\text { Skin mucus Iysozyme activity } \uparrow, \\
\text { Spleen: IL-12p40 } \uparrow, \text { IFN- } \gamma \uparrow \text {, } \\
\text { Intestine: IL-6 } \uparrow, \text { IL-8 } \uparrow, \\
\text { Protection from S. iniae } \uparrow\end{array}$ & $\begin{array}{l}\text { Kim et al., 2013; } \\
\text { Beck et al., } 2015\end{array}$ \\
\hline L. lactis BFE920 & $\begin{array}{l}\text { Olive flounder } \\
(42.7 \pm 1.61 \mathrm{~g})\end{array}$ & $\begin{array}{l}\text { Diet } \\
10^{7} \mathrm{CFU} / \mathrm{g} \text { feed }\end{array}$ & 4 weeks & $\begin{array}{l}\text { Intestine: CD } 4-1 \uparrow, \text { FOXP3 } \uparrow, \mathrm{IL}-10 \uparrow \text {, } \\
\text { TGF- } \beta 1 \uparrow, \text { IFN- } \gamma \uparrow, \text { ROR } \gamma \downarrow \text {, IL-17A/F } \downarrow \text {, } \\
\text { Gut permeability } \downarrow \text {, } \\
\text { Protection from } E \text {. tarda } \uparrow\end{array}$ & Beck et al., 2016 \\
\hline $\begin{array}{l}\text { L. lactis ssp. lactis } \\
\text { CLFP } 100\end{array}$ & Rainbow trout (40 g) & $\begin{array}{l}\text { Diet } \\
10^{6} \mathrm{CFU} / \mathrm{g} \text { feed }\end{array}$ & 2 weeks & $\begin{array}{l}\text { Alternative complement activity } \uparrow, \\
\text { NBT reaction (respiratory burst) } \uparrow, \\
\text { Phagocytic activity } \uparrow, \\
\text { Serum lysozyme activity } \uparrow \text {, } \\
\text { Protection from } A \text {. salmonicida } \uparrow\end{array}$ & $\begin{array}{l}\text { Balcázar et al., } \\
\text { 2007b }\end{array}$ \\
\hline
\end{tabular}


TABLE 7 | Continued

\begin{tabular}{|c|c|c|c|c|c|}
\hline LAB & Fish model (weight) & $\begin{array}{l}\text { Administration route } \\
\text { and dose }\end{array}$ & $\begin{array}{l}\text { Administration } \\
\text { length }\end{array}$ & Immunological changes & References \\
\hline L. lactis WFLU12 & $\begin{array}{l}\text { Olive flounder } \\
(80.84 \pm 9.37 \mathrm{~g})\end{array}$ & $\begin{array}{l}\text { Diet } \\
10^{9} \mathrm{CFU} / \mathrm{g} \text { feed }\end{array}$ & $\begin{array}{l}2,4,8 \text { weeks } \\
\text { (consecutive) }\end{array}$ & $\begin{array}{l}\text { Intestine: IL-6 (at week 4) } \uparrow \\
\text { Kidney: IL-6 (at week } 2 \text { ) } \uparrow, ~ I L-8 \text { (at week 4) } \\
\uparrow, \text { IFN- } \gamma \text { (at week 4) } \uparrow, \text { g-lysozyme (at } \\
\text { week 4) } \uparrow \\
\text { Phagocytic activity (at week } 2 \text { ) } \uparrow, \\
\text { NBT reaction (respiratory burst, at week 4) } \\
\uparrow, \\
\text { Natural infection of S. parauberis } \downarrow\end{array}$ & Nguyen et al., 2017 \\
\hline $\begin{array}{l}\text { Lc. mesenteroides } \\
\text { CLFP } 196\end{array}$ & Rainbow trout (40 g) & $\begin{array}{l}\text { Diet } \\
10^{6} \mathrm{CFU} / \mathrm{g} \text { feed }\end{array}$ & 2 weeks & $\begin{array}{l}\text { Alternative complement activity } \uparrow, \\
\text { Phagocytic activity } \uparrow, \\
\text { NBT reaction (respiratory burst) } \uparrow, \\
\text { Serum lysozyme activity } \uparrow, \\
\text { Protection from } A \text {. salmonicida } \uparrow\end{array}$ & $\begin{array}{l}\text { Balcázar et al., } \\
\text { 2007b }\end{array}$ \\
\hline $\begin{array}{l}\text { P. acidilactici MA } \\
18 / 5 \mathrm{M}\end{array}$ & $\begin{array}{l}\text { Green terror (Aequidens } \\
\text { rivulatus) } \\
(0.388 \pm 0.0021 \mathrm{~g})\end{array}$ & $\begin{array}{l}\text { Diet } \\
0.9 \times 10^{7} \mathrm{CFU} / \mathrm{g} \text { feed }\end{array}$ & 56 days & $\begin{array}{l}\text { Alternative complement activity } \uparrow \text {, } \\
\text { Serum lysozyme activity } \uparrow \text {, } \\
\text { Total immunoglobulin counts } \uparrow\end{array}$ & Neissi et al., 2013 \\
\hline $\begin{array}{l}\text { P. pentosaceus } \\
\text { PKWA-1 }\end{array}$ & $\begin{array}{l}\text { Nile tilapia }(0.68 \pm 0.02 \mathrm{~g} \\
36.89 \pm 3.34 \mathrm{~g})\end{array}$ & $\begin{array}{l}\text { Diet } \\
10^{7} \mathrm{CFU} / \mathrm{g} \text { feed }\end{array}$ & $\begin{array}{l}1,14,28,42 \\
\text { days } \\
\text { (consecutive) }\end{array}$ & $\begin{array}{l}\text { Alternative complement activity } \uparrow \text {, } \\
\text { Phagocytic activity } \uparrow, \\
\text { Serum lysozyme activity } \uparrow, \\
\text { Total leukocyte counts } \uparrow, \\
\text { Protection from } A \text {. hydrophila } \uparrow\end{array}$ & Kaew-on et al., 2016 \\
\hline $\begin{array}{l}\text { Mixed LAB (Lb. } \\
\text { plantarum } \\
\text { FGL0001, L. lactis } \\
\text { BFE920) }\end{array}$ & $\begin{array}{l}\text { Olive flounder } \\
(37.5 \pm 1.26 \mathrm{~g})\end{array}$ & $\begin{array}{l}\text { Diet } \\
10^{7} \mathrm{CFU} / \mathrm{g} \text { feed of } \\
\text { each strain }\end{array}$ & 4 weeks & $\begin{array}{l}\text { NBT reaction (respiratory burst) } \uparrow \text {, } \\
\text { Phagocytic activity } \uparrow, \\
\text { Skin mucus lysozyme activity } \uparrow, \\
\text { Intestine: IL-6 } \uparrow, \mathrm{IL}-8 \uparrow, \mathrm{TNF}-\alpha \uparrow \text {, } \\
\text { Protection from } S \text {. iniae } \uparrow\end{array}$ & Beck et al., 2015 \\
\hline $\begin{array}{l}\text { Mixed LAB (Lb. } \\
\text { plantarum SM16, } \\
\text { Lb. plantarum } \\
\text { SM33, Lb. } \\
\text { fermentum SM51, } \\
\text { Lb. brevis SM56, } \\
\text { P. pentosaceus } \\
\text { SM65) }\end{array}$ & Rohu (19.72 $\pm 0.18 \mathrm{~g})$ & $\begin{array}{l}\text { Diet } \\
2 \times 10^{8} \mathrm{CFU} / \mathrm{g} \text { feed of } \\
\text { each strain }\end{array}$ & 30 days & $\begin{array}{l}\text { NBT reaction (respiratory burst) } \uparrow \text {, } \\
\text { Intestine and liver: TNF- } \alpha \uparrow, \mathrm{IL}-10 \uparrow \\
\text { Protection from } A \text {. hydrophila } \uparrow\end{array}$ & Maji et al., 2017 \\
\hline
\end{tabular}

demonstrated better immunostimulant effects, compared to any other modes of application. The viability of LAB is another important issue to consider. The viability of microbes is a necessity for probiotics by definition. In general, live LAB triggered higher immune stimulation compared to that of the inactivated LAB (Panigrahi et al., 2005; Munoz-Atienza et al., 2015; Tables 7, 8). However, more studies that compare the activities between the live and the inactivated condition of the same LAB need to be done for further confirmation. Nevertheless, only live LAB can produce bioactive products such as exopolysaccharides and maintain the natural state of microbeassociated molecular patterns (MAMP) structures. These unique properties of live LAB may contribute to the superiority in immunostimulant effects over the inactivated form of the LAB. In this context, the establishment of proper techniques for storing and applying live $\mathrm{LAB}$ is an important aspect to consider. As summarized in Table 8, the inactive LAB also showed significant immunostimulant effects, but less than those of live LAB. However, in the aspect of manufacturing LAB products, the inactivated condition of LAB may be advantageous because the cost for storage and distribution can be reduced. For the practical utilization of LAB in the finfish aquaculture field, the species, the living status, the mode of administration, and the optimum dosage of the LAB should be carefully considered for the best results.

\section{LAB EFFECTS ON INNATE IMMUNITY}

Innate immunity takes the place of the first line of defense toward a wide range of pathogens. The interaction between MAMP in microbes and pattern-recognition receptors (PRR) on innate immune cells is one of the critical initiators for activation of the innate immune system. Some probiotics that have immunostimulant activity such as LAB can protect the host from various pathogens by stimulating the immune system. The LAB studies of warm-blooded animals seem to influence the similar studies in finfish. However, the finfish studies were heavily biased toward the LAB effects on innate immunity as shown Tables 7, 8. Furthermore, most of the studies simply described the physiological status without exploring the specific immune subsets responsible for disease resistance or the underlying mechanism. The studies of the adaptive immune system are even more limited. Antibody was the only subject studied, and the studies concerning $\mathrm{T}$ cell responses were very few, if any. 
TABLE 8 | Immunological changes of finfish resulted by inactivated LAB treatment.

\begin{tabular}{|c|c|c|c|c|c|}
\hline LAB & Fish model (weight) & $\begin{array}{l}\text { Administration route } \\
\text { and dose }\end{array}$ & $\begin{array}{l}\text { Administration } \\
\text { length }\end{array}$ & Immunological changes & References \\
\hline $\begin{array}{l}\text { E. faecalis } \\
\text { (Nichinichi } \\
\text { Pharmaceutical, } \\
\text { Japan) }\end{array}$ & $\begin{array}{l}\text { Rainbow trout } \\
\text { (Oncorhynchus mykiss) } \\
(36.3 \pm 0.42 \mathrm{~g})\end{array}$ & $\begin{array}{l}\text { Diet } \\
0.25,0.5 \% \mathrm{w} / \mathrm{w} \\
\text { inclusion to feeds }\end{array}$ & 12 weeks & $\begin{array}{l}\text { Mucus secretion } \uparrow, \\
\text { Phagocytic activity } \uparrow, \\
\text { Protection from } A \text {. salmonicida } \uparrow \\
\text { Systemic invasion of } A \text {. salmonicida } \downarrow\end{array}$ & $\begin{array}{l}\text { Rodriguez-Estrada } \\
\text { et al., } 2013\end{array}$ \\
\hline E. faecalis $\mathrm{KH} 2$ & $\begin{array}{l}\text { Goldfish (Carassius } \\
\text { auratus)(15-20 g) } \\
\text { In vitro, kidney leukocytes }\end{array}$ & $\begin{array}{l}\text { In vivo, intraperitoneal } \\
\text { injection } \\
500 \mu \mathrm{g} / \text { fish } \\
\text { In vitro treatment } \\
50 \mu \mathrm{g} / \text { well }\end{array}$ & $\begin{array}{l}\text { In vivo, } 7 \\
\text { days; In vitro, } \\
12 \mathrm{~h}\end{array}$ & $\begin{array}{l}\text { In vivo: CD4- } 1^{+} \text {cells } \uparrow, \text { CD } 8 \alpha^{+} \text {cells } \uparrow \\
\text { Myeloid cells } \uparrow, \text { Macrophages } \uparrow, I L-12 p 35 \\
\uparrow, \text { IL-12p40 } \uparrow, \text { IFN- } \gamma 1 \uparrow \\
\text { In vitro: IL4/13a } \uparrow, \text { IL-12p35 } \uparrow, ~ I L-12 p 40 \\
\uparrow, ~ I F N-\gamma 1 \uparrow, \text { IFN- } \gamma 2 \uparrow, \text { infgrel } 1 \uparrow, \text { infgrel } 2 \uparrow\end{array}$ & $\begin{array}{l}\text { Matsuura et al., } \\
2017\end{array}$ \\
\hline $\begin{array}{l}\text { Lb. delbrueckii } \\
\text { ssp. lactis } \\
\text { CECT287 }\end{array}$ & $\begin{array}{l}\text { Gilthead sea bream } \\
\text { (Sparus aurata L.)(65 g) } \\
\text { In vitro, head kidney cells }\end{array}$ & $\begin{array}{l}\text { In vitro treatment } \\
5 \times 10^{5}, 5 \times 10^{6} 5 \times \\
10^{7} \mathrm{CFU} / \mathrm{mL}\end{array}$ & $30 \mathrm{~min}$ & $\begin{array}{l}\text { Respiratory burst } \uparrow \text {, Natural cytotoxic } \\
\text { activity } \uparrow \text {, }\end{array}$ & Salinas et al., 2006 \\
\hline $\begin{array}{l}\text { Lb. paracasei spp. } \\
\text { paracasei } \\
\text { 06TCa22 }\end{array}$ & $\begin{array}{l}\text { Tiger puffer (Takifugu } \\
\text { rubripes) } \\
(205 \pm 8 \mathrm{~g}) \\
\text { In vitro, head kidney cells }\end{array}$ & $\begin{array}{l}\text { In vitro treatment } \\
20 \mu \mathrm{g} / \mathrm{mL}\end{array}$ & $\begin{array}{l}1,4,8,12 \\
24,48 h\end{array}$ & $\begin{array}{l}\mathrm{IL}-1 \beta \uparrow, \mathrm{IL}-2 \uparrow, \mathrm{IL}-6 \uparrow, \mathrm{IL}-7 \uparrow, \mathrm{IL}-12 \mathrm{p} 40 \uparrow \\
\mathrm{IL}-17 \mathrm{AF}-3 \uparrow, \mathrm{IL}-18 \uparrow, \mathrm{TNF}-\alpha \uparrow, \mathrm{TNF}-\mathrm{N} \uparrow \\
\mathrm{I}-\mathrm{IFN}-1 \uparrow, \mathrm{IFN}-\gamma \uparrow\end{array}$ & Biswas et al., 2013 \\
\hline $\begin{array}{l}\text { Lb. plantarum } \\
\text { 06CC2 }\end{array}$ & $\begin{array}{l}\text { Tiger puffer } \\
(205 \pm 8 \mathrm{~g}) \\
\text { In vitro, head kidney cells }\end{array}$ & $\begin{array}{l}\text { In vitro treatment } \\
20 \mu \mathrm{g} / \mathrm{mL}\end{array}$ & $\begin{array}{l}1,4,8,12 \\
24,48 h\end{array}$ & $\begin{array}{l}\mathrm{IL}-1 \beta \uparrow, \mathrm{IL}-2 \uparrow, \mathrm{IL}-6 \uparrow, \mathrm{IL}-7 \uparrow, \mathrm{IL}-12 \mathrm{p} 40 \uparrow \\
\mathrm{IL}-10 \uparrow, \mathrm{IL}-15 \uparrow, \mathrm{IL}-18 \uparrow, \mathrm{IL}-21 \uparrow, \mathrm{TNF}-\alpha \\
\uparrow, \mathrm{TNF}-\mathrm{N} \uparrow, \mathrm{I}-\mathrm{IFN}-1 \uparrow\end{array}$ & Biswas et al., 2013 \\
\hline $\begin{array}{l}\text { P. pentosaceus } \\
\text { D3268 }\end{array}$ & $\begin{array}{l}\text { Red sea bream (Pagrus } \\
\text { major) } \\
(6 \pm 0.2 \mathrm{~g})\end{array}$ & $\begin{array}{l}\text { Diet } \\
1.6 \times 10^{10}, 1.6 \times \\
10^{11}, 1.6 \times 10^{12}, 3.2 \\
\times 10^{12} \mathrm{CFU} / \mathrm{g} \text { feed }\end{array}$ & 56 days & $\begin{array}{l}\text { Mucus lysozyme activity } \uparrow \text {, } \\
\text { Mucus secretion } \uparrow \text {, } \\
\text { Serum lysozyme activity } \uparrow\end{array}$ & $\begin{array}{l}\text { Dawood et al., } \\
2016 a\end{array}$ \\
\hline
\end{tabular}

Understanding the regulatory mechanism of the finfish immune system is a big challenge to the field of finfish immunology. This understanding is essential for developing safe and potent immunological means for the protection and cure of fish diseases.

\section{IMMUNE PARAMETERS FOR STUDYING FINFISH IMMUNITY}

The immune parameters that have frequently been used for studying finfish immunity are listed and briefly explained in Table 9. The innate immune parameters include complement activity, lysozyme, phagocytosis, and respiratory burst. The level of antigen-specific antibodies is mostly used for representing adaptive immune responses. The types and the levels of cytokines are important indicators of both innate and adaptive immune status of fish.

\section{CYTOKINES AS IMPORTANT IMMUNE MODULATORS OF FINFISH IMMUNITY}

Cytokines are small proteins $(\sim 5-20 \mathrm{KDa})$ that are important in cell signaling. They act through receptors and are particularly important in the immune system because cytokines modulate the balance between humoral and cellular immune responses. Cytokines regulate the maturation, growth, and responsiveness of particular cell populations (Abbas et al., 2014; Turner et al., 2014). Many studies demonstrated the cytokine induction effects of LAB in various finfish models (Picchietti et al., 2009; Kim et al., 2012, 2013; Biswas et al., 2013; Liu et al., 2013; Beck et al., 2015, 2016; Matsuura et al., 2017; Nguyen et al., 2017;
Zhang Z. et al., 2017). The cytokine profiles modified by LAB administration are summarized in Tables 7, 8. Increased expression of proinflammatory cytokines (e.g., IL-1 $\beta$, IL-6, IL8 , or TNF- $\alpha$ ) directly correlates to disease protection against challenged pathogens. This protective activity of inflammatory cytokines may be because of the potentiation of the host immune system, resulting in rapid and efficient responses to the invading pathogens (Wang and Secombes, 2013; Turner et al., 2014). However, excessive inflammation can cause acute inflammatory symptoms leading to the death of the host. Therefore, maintaining a balanced inflammation status is critical. IL-10, an anti-inflammatory cytokine, is a well-known immune regulator. Some strains of dietary LAB induced $I L-10$ expression in finfish; Biswas et al. (2013) (Lb. plantarum 06CC2 treated T. rubripes), Beck et al. (2016) (L. lactis BFE920 treated P. olivaceus), and Maji et al. (2017) (a mixture of Lb. plantarum SM16, Lb. plantarum SM33, Lb. fermentum SM51, Lb. brevis SM56, P. pentosaceus SM65 treated Labeo rohita). Beck and co-authors demonstrated that LAB plays an important role in the establishment of the "immune tone" in the finfish gut. The immune tone is a higher status of immunological-readiness to combat against pathogens. LAB established the proinflammatory or anti-inflammatory immune tone in a strain-specific manner. The finfish in proinflammatory immune tone was able to protect the challenged pathogen better compared to those with an anti-inflammatory immune tone. However, the fish in antiinflammatory immune tone gained more weight (Beck et al., 2016). Therefore, monitoring the types of cytokines expressed after LAB treatment may be important to maximize the beneficial effects of the LAB. The underlying mechanisms involved in the establishment of the two different types of immune tones and 
TABLE 9 | Frequently measured immune parameters in finfish studies.

\begin{tabular}{|c|c|c|}
\hline $\begin{array}{l}\text { Immune } \\
\text { parameters }\end{array}$ & Functions & References \\
\hline Antibody & $\begin{array}{l}\text { Produced by B cells } \\
\text { Recognizes and binds to specific } \\
\text { antigens of pathogens } \\
\text { Neutralization of pathogens } \\
\text { Opsonization of antibody bound } \\
\text { pathogens } \\
\text { Activation of the complement system } \\
\text { Activation of antibody-dependent } \\
\text { cellular cytotoxicity }\end{array}$ & Abbas et al., 2014 \\
\hline Cytokine & $\begin{array}{l}\text { Signal proteins of host cells } \\
\text { Activation of inflammation through } \\
\text { proinflammatory cytokines (eg., IL-1 } \beta \text {, } \\
\text { INF- } \gamma, \mathrm{TNF}-\alpha \text { ) } \\
\text { Regulation of immune } \\
\text { activities/anti-inflammation through } \\
\text { regulatory cytokines (eg., IL-10, TGF- } \beta \text { ) }\end{array}$ & $\begin{array}{l}\text { Wang and } \\
\text { Secombes, 2013; } \\
\text { Abbas et al., 2014; } \\
\text { Turner et al., 2014 }\end{array}$ \\
\hline $\begin{array}{l}\text { Complement } \\
\text { activity }\end{array}$ & $\begin{array}{l}\text { Non-cellular immune response which } \\
\text { is activated by antigen-specific } \\
\text { antibodies or lectin } \\
\text { Formation of membrane attack } \\
\text { complexes (MAC) of the surface of } \\
\text { pathogens } \\
\text { Induction of inflammation at local } \\
\text { infection sites } \\
\text { Opsonization of pathogens by } \\
\text { antibody binding or complement } \\
\text { subunits to the surface of pathogens }\end{array}$ & $\begin{array}{l}\text { Alexander and } \\
\text { Ingram, 1992; } \\
\text { Abbas et al., } 2014\end{array}$ \\
\hline Lysozyme & $\begin{array}{l}\text { Non-cellular immune response toward } \\
\text { bacterial pathogens } \\
\text { Hydrolysis } \beta-(1,4) \text { glycosidic linkages } \\
\text { in } \mathrm{N} \text {-acetylmuramic acid and } \\
\mathrm{N} \text {-acetylglucosamine of bacterial cell } \\
\text { wall peptidoglycan }\end{array}$ & $\begin{array}{l}\text { Alexander and } \\
\text { Ingram, } 1992\end{array}$ \\
\hline Phagocytosis & $\begin{array}{l}\text { Engulfing activity of phagocytic cells } \\
\text { such as dendritic cells, macrophages, } \\
\text { and monocytes } \\
\text { Direct killing of pathogen by } \\
\text { intracellular lysosome of phagocytic } \\
\text { cells } \\
\text { Antigen presentation of phagocytosed } \\
\text { antigens to T cell by dendritic cells and } \\
\text { macrophages }\end{array}$ & Abbas et al., 2014 \\
\hline $\begin{array}{l}\text { Respiratory } \\
\text { burst }\end{array}$ & $\begin{array}{l}\text { Oxidative potential of innate cells } \\
\text { Pathogen killing effect by reactive } \\
\text { oxygen species including hydrogen } \\
\text { peroxide, superoxide anions, and } \\
\text { hydroxyl radicals }\end{array}$ & Abbas et al., 2014 \\
\hline
\end{tabular}

their relationships to the adaptive immune system need to be further investigated.

\section{LAB EFFECTS ON ADAPTIVE IMMUNITY}

In addition to innate immunity, LAB treatment also influenced the adaptive immunity of finfish. The fish fed with LAB increased total $\mathrm{T}$ cell numbers (Picchietti et al., 2009). The LAB also activated the subtype-specific factors of $\mathrm{CD}^{+}{ }^{+} \mathrm{T}$ helper cells (Th1, Th2, Th17, and Treg cell) (Beck et al., 2016) and CD8 ${ }^{+}$ cytotoxic T cells (Beck et al., 2016; Matsuura et al., 2017). The modification of $\mathrm{T}$ cell composition may be due to the cytokines released from various subsets of immune cells that are induced by the treated LAB. IL-12, IL-18, and IFN- $\gamma$ act on Th1 cell differentiation and activation. IL-4, IL-13, IL-5 are involved in Th2 cells, and IL-17, IL-22, IL-21 promote Th17 cell differentiation. Treg cell differentiation is controlled by IL-10 and TGF- $\beta$ (Abbas et al., 2014). The relationships between cytokines and immune cells are mutually regulated; cytokines secreted from stimulated immune cells control the same or other immune cells through signaling pathways. The responding immune cells then release cytokines accordingly (Knosp and Johnston, 2012). The cytokine networks are closely linked between the innate and the adaptive immune system as well. IL-10 released from activated M2 macrophages (Martinez and Gordon, 2014) influences Treg cell differentiation. Also, IL-12 released by activated DCs and macrophages stimulate Th1 cells and NK cells to release IFN$\gamma$. This IFN- $\gamma$ then activates DCs and macrophages. The LAB's roles involved in this kind of immune modulation have been well-demonstrated in warm-blooded animals (Delcenserie et al., 2008; Bron et al., 2012). Although it appears that LAB play similar roles in the finfish immune system, further studies are required.

\section{CONCLUSIONS}

Numerous reports exist in finfish regarding the microbiota modulating effects of dietary modifications and the presence of $\mathrm{LAB}$ in the GI tract. However, when investigating the GI tract microbiota, one major concern occur; most studies evaluating the fish gut microbiota have focus to characterize the communities in the GI lumen (the allochthonous microbiota), while those bacteria that adhere to the mucosal surface (the autochthonous microbiota); which may be important in specialized physiological functions, remain uncharacterized. We therefore recommend more focus on the autochthonous gut microbiota in future studies.

Previous studies were based on culture-based approaches, but this may be question. Although there is a discussion over the value and need of using culture-based techniques vs. cultureindependent approaches, it is apparent that viable cells are valuable to culture collections, in vaccine production, and as probiotics and synbiotics. During the last decades, 16S rRNA gene fingerprinting methods such as denaturing gradient gel electrophoresis (DGGE) have been widely used, but the DGGE method only detect $1-2 \%$ of the microbial diversity. NextGeneration Sequencing (NGS) has been used in recent years to examine the gut microbiome of humans, terrestrial and marine vertebrate including some finfish species. However, as NGS has only been used in few finfish species such as rainbow trout, Atlantic salmon, Siberian sturgeon, zebrafish and gilthead sea bream, we recommend that this technique is used to explore the gut bacterial community of finfish. 
$\mathrm{LAB}$ and their bacteriocins are alternatives to chemicals and antibiotics as antimicrobial activities toward pathogens have been revealed. In some cases $\mathrm{LAB}$ and their bacteriocins may be used in combination with low dosages of antibiotics. As novel applications of $L A B$ and bacteriocins are increasing; within prospects of anti-quorum sensing strategies and site-specific drug delivery, this topic merits further investigations.

As the specific bio-active compounds and mechanism behind the antagonism of LAB bacteriocins have rarely investigated, this merits further investigations to validate the health claims. Furthermore, as there may be risk of possible horizontal transfer of antibiotic resistance genes through $\mathrm{LAB}$, the use of promising $\mathrm{LAB}$ must follow strict guidelines in addition to antimicrobial actions. As the efficacy of the bacteriocins is dictated by environmental factors, there is also a need to determine the effective conditions for application of each LAB bacteriocin (Balciunas et al., 2013).

Recent studies regarding probiotic administration as revealed beneficial effects on growth performance, immune responses and disease resistance. However, still there is limited information available about the exact mode of action on physiology of host organism. Although, there are some assumptions and speculations, this should be clarified in future through in depth studies. Also, different studies revealed varied results on different species. Considering the species-specific effects, there should be studies to determined optimum probiotic and inclusion level for each cultured species. During the recent years, there has been increased attention toward probiotics effects on mucosal parameters and expression of immune, and antioxidant related genes expression. The possible mode of action on gene expression profile merit further researches.

In addition to the numerous beneficial LAB, there are several pathogenic species within genera Streptococcus,

\section{REFERENCES}

Abbas, A. K., Lichtman, A. H., and Pillai, S. (2014). Cellular and Molecular Immunology, 8th Edn. Philadelphia, PA: Saunders Elsevier.

Abou El-Geit, E., Saad, T., Abdo, M., and Mona, S. Z. (2013). Microbial infections among some fishes and crustacean species during blooming phenomenon in Qaroun Lake-Egypt. Life Sci. J. 10, 1217-1224. Available online at: http://www.lifesciencesite.com

Adel, M., Safari, R., Yeganeh, S., Binaii, M., Ghiasi, M., and Ahmadvad, S. (2017). Effects of dietary GroBiotic ${ }^{\circledR}$ - A supplementation as a probiotic on the intestinal microflora, growth performance, haemato-serological parameters, survival rate and body composition in juvenile beluga (Huso huso Linnaeus, 1754). Aquacult. Nutr. 23, 492-499. doi: 10.1111/anu. 12417

Adel, M., Yeganeh, S., Dadar, M., Sakai, M., and Dawood, M. A. O. (2016). Effects of dietary Spirulina platensis on growth performance, humoral and mucosal immune responses and disease resistance in juvenile great sturgeon (Huso huso Linnaeus, 1754). Fish Shellfish Immunol. 56, 436-444. doi: 10.1016/j.fsi.2016.08.003

Agnew, W., and Barnes, A. C. (2007). Streptococcus iniae: an aquatic pathogen of global veterinary significance and a challenging candidate for reliable vaccination. Vet. Microbiol. 122, 1-15. doi: 10.1016/j.vetmic.2007. 03.002
Enterococcus, Lactobacillus, Carnobacterium, and Lactococcus. They have caused considerable losses in aquaculture practice. Huge effort been contributed to deal with these pathogens such as vaccines, dietary supplements; medicinal plants, prebiotics, probiotics and other immunostimulants. Such treatments needs to be developed in the future for sustainable aquaculture.

It is quite clear that $\mathrm{LAB}$ administration results in beneficial effects such as disease resistance and weight gain in finfish aquaculture. However, the underlying mechanism is poorly understood; the microbe-associated molecular patterns (MAMPs) of the LAB, their pattern recognition receptors (PRRs) on immune cells, and byproducts released from the $\mathrm{LAB}$ that are responsible for immunomodulation. The immunomodulatory effects of the LAB are strainspecific, and therefore, the information of the studies performed with various strains of LAB need to be further accumulated and actively shared for finfish aquaculture industries.

\section{AUTHOR CONTRIBUTIONS}

ER: introduction, GI tract, editorial. KG: antibacterial effects of LAB. SH: LAB as probiotic. HD: pathogenic LAB. BB and SS: immunology of LAB.

\section{FUNDING}

National Research Foundation of Korea (NRF2015R1D1A1A01056959) and the Korea GyeongSangbuk-Do Fisheries Technology Center support SS. The publication charges for this article have been funded by a grant from the publication fund of UiT The Arctic University of Norway.
Aguado-Urda, M., López-Campos, G. H., Gibello, A., Cutuli, M. T., López-Alonso, V., Fernández-Garayzábal, J. F., et al. (2011). Genome sequence of Lactococcus garvieae 8831, isolated from rainbow trout Lactococcosis outbreaks in Spain. J. Bacteriol. 193, 4263-4264. doi: 10.1128/JB.05326-11

Alakomi, H. L., Skyttä, E., Saarela, M., Mattila-Sandholm, T., Latva-Kala, K., and Helander, I. M. (2000). Lactic acid permeabilizes gram-negative bacteria by disrupting the outer membrane. Appl. Environ. Microbiol. 66, 2001-2005. doi: 10.1128/AEM.66.5.2001-2005.2000

Alexander, J. B., and Ingram, G. A. (1992). Noncellular nonspecific defense mechanisms of fish. Ann. Rev. Fish Dis. 2, 249-280. doi: 10.1016/0959-8030(92)90066-7

Al-Harbi, A. H. (2011). Molecular characterization of Streptococcus iniae isolated from hybrid tilapia (Oreochromis niloticus $\times$ Oreochromis aureus). Aquaculture 312, 15-18. doi: 10.1016/j.aquaculture.2010.12.014

Al-Harbi, A. H. (2016). Phenotypic and genotypic characterization of Streptococcus agalactiae isolated from hybrid tilapia (Oreochromis niloticus $\times$ O. aureus). Aquaculture 464, 515-520. doi: 10.1016/j.aquaculture.2016.07.036

Allameh, S. K., Yusoff, F. M., Ringø, E., Daud, H. M., Saad, C. R., and Ideris, A. (2016). Effects of dietary mono- and multiprobiotic strains on growth performance, gut bacteria and body composition of Javanese carp (Puntius gonionotus, Bleeker 1850). Aquacult. Nutr. 22, 367-373. doi: 10.1111/anu. 12265

Allameh, S., Ringø, E., Yusoff, F., Daud, H., and Ideris, A. (2015). Dietary supplement of Enterococcus faecalis on digestive enzyme activities, short-chain 
fatty acid production, immune system response and disease resistance of Javanese carp (Puntius gonionotus, Bleeker 1850). Aquacult. Nutr. 23, 331-338. doi: 10.1111/anu.12397

Almeida, T., Brandao, A., Muñoz-Atienza, E., Gonçalves, A., Torres, C., Igrejas, G., et al. (2011). Identification of bacteriocin genes in enterococci isolated from game animals and saltwater fish. J. Food Protect. 74, 1252-1260. doi: 10.4315/0362-028X.JFP-11-016

Aly, S. M., Abdel-Galil Ahmed, Y., Abdel-Aziz Ghareeb, A., and Mohamed, M. F. (2008). Studies on Bacillus subtilis and Lactobacillus acidophilus, as potential probiotics, on the immune response and resistance of tilapia nilotica (Oreochromis niloticus) to challenge infections. Fish Shellfish Immunol. 25, 128-136. doi: 10.1016/j.fsi.2008.03.013

Amal, M. N. A., Zamri-Saad, M., Iftikhar, A. R., Siti-Zahrah, A., Aziel, S., and Fahmi, S. (2012). An outbreak of Streptococcus agalactiae infection in cagecultured golden pompano, Trachinotus blochii (Lacépède), in Malaysia. J. Fish Dis. 35, 849-852. doi: 10.1111/j.1365-2761.2012.01443.x

Annamalai, N., Manivasagan, P., Balasubramanian, T., and Vijayalakshmi, S. (2009). Enterocin from Enterococcus faecium isolated from mangrove environment. Afr. J. Biotechnol. 8, 6311-6316. doi: 10.5897/AJB2009.000-9478

Aoki, T., Takami, K., and Kitao, T. (1990). Drug resistance in a non-hemolytic Streptococcus sp. isolated from cultured yellowtail Seriola quinqueradiata. Dis. Aquat. Org. 8, 171-177. doi: 10.3354/dao008171

Arlindo, S., Calo, P., Franco, C., Prado, M., Cepeda, A., and Barros-Velázquez, J. (2006). Single nucleotide polymorphism analysis of the enterocin P structural gene of Enterococcus faecium strains isolated from nonfermented animal foods. Mol. Nutr. Food Res. 50, 1229-1238. doi: 10.1002/mnfr.200600178

Austreng, E. (1978). Digestibility determination in fish using chromic oxide marking and analysis of contents from different segments if the gastrointestinal tract. Aquaculture 13, 265-272. doi: 10.1016/0044-8486(78)90008-X

Baba, E., Uluköy, G., and Öntaş, C. (2015). Effects of feed supplemented with Lentinula edodes mushroom extract on the immune response of rainbow trout, Oncorhynchus mykiss, and disease resistance against Lactococcus garvieae. Aquaculture 448, 476-482. doi: 10.1016/j.aquaculture.2015.04.031

Bahramian, S., and Parsa, A. (2017). A survey of growth performance, intestinal micro-flora and meat shelf-life in rainbow trout fed with Pistacia atlantica kurdica essential oil. Iran. J. Fish. Sci. 16, 619-624.

Bakkal, S., Robinson, S. M., and Riley, M. A. (2012). "Bacteriocins of aquatic microorganisms and their potential applications in the seafood industry," in Health and Environment in Aquaculture, ed E. Carvalho (Croatia: InTech), 303-328.

Balcázar, J. L., De Blas, I., Ruiz-Zarzuela, I., Vendrell, D., Girones, O., and Muzquiz, J. L. (2007b). Enhancement of the immune response and protection induced by probiotic lactic acid bacteria against furunculosis in rainbow trout (Oncorhynchus mykiss). FEMS Immunol. Med. Microbiol. 51, 185-193. doi: 10.1111/j.1574-695X.2007.00294.X

Balcázar, J. L., Vendrell, D., de Blas, I., Ruiz-Zarzuela, I., Gironés, O., and Múzquiz, J. L. (2007a). In vitro competitive adhesion and production of antagonistic compounds by lactic acid bacteria against fish pathogens. Vet. Microbiol. 122, 373-380. doi: 10.1016/j.vetmic.2007.01.023

Balciunas, E. M., Martinez, F. A. C., Todorov, S. D., de Melo, G., Franco, B. D., Converti, A., et al. (2013). Novel biotechnological applications of bacteriocins: a review. Food Control 32, 134-142. doi: 10.1016/j.foodcont.2012.11.025

Banerjee, G., and Ray, A. K. (2017). The advancement of probiotic research and its application in fish farming industries. Res. Vet. Sci. 115, 66-77. doi: 10.1016/j.rvsc.2017.01.016

Banerjee, S. P., Dora, K. C., and Chowdhury, S. (2013). Detection, partial purification and characterization of bacteriocin produced by Lactobacillus brevis FPTLB3 isolated from freshwater fish. J. Food Sci. Technol. 50, 17-25. doi: 10.1007/s13197-011-0240-4

Bastardo, A., Ravelo, C., Castro, N., Calheiros, J., and Romalde, J. L. (2012). Effectiveness of bivalent vaccines against Aeromonas hydrophila and Lactococcus garvieae infections in rainbow trout Oncorhynchus mykiss (Walbaum). Fish Shellfish Immunol. 32, 756-761. doi: 10.1016/j.fsi.2012. 01.028

Baya, A. M., Toranzo, A. E., Lupiani, B., Li, T., Roberson, B. S., and Hetrick, F. M. (1991). Biochemical and serological characterization of Carnobacterium spp. isolated from farmed and natural populations of striped bass and catfish. Appl. Environ. Microbiol. 57, 3114-3120.
Beasley, S. S., and Saris, P. E. J. (2004). Nisin-producing Lactococcus lactis strains isolated from human milk. Appl. Environ. Microbiol. 70, 5051-5053. doi: 10.1128/AEM.70.8.5051-5053.2004

Beck, B. R., Kim, D., Jeon, J., Lee, S.-M., Kim, H. K., Kim, O.-J., et al. (2015). The effects of combined dietary probiotics Lactococcus lactis BFE920 and Lactobacillus plantarum FGL0001 on innate immunity and disease resistance in olive flounder (Paralichthys olivaceus). Fish Shellfish Immunol. 42, 177-183. doi: 10.1016/j.fsi.2014.10.035

Beck, B. R., Song, J. H., Park, B. S., Kim, D., Kwak, J.-H., Do, H. K., et al. (2016). Distinct immune tones are established by Lactococcus lactis BFE920 and Lactobacillus plantarum FGL0001 in the gut of olive flounder (Paralichthys olivaceus). Fish Shellfish Immunol. 55, 434-443. doi: 10.1016/j.fsi.2016.06.022

Belicova, A., Mikulasova, M., and Dusinsky, R. (2013). Probiotic potential and safety properties of Lactobacillus plantarum from Slovak bryndza cheese. BioMed Res Int. 2013:760298. doi: 10.1155/2013/760298

Bercovier, H., Ghittino, C., and Eldar, A. (1997). Immunization with bacterial antigens: infections with streptococci and related organisms. Dev. Biol. 90, $153-160$.

Bhugaloo-Vial, P., Dousset, X., Metivier, A., Sorokine, O., Anglade, P., Boyaval, P., et al. (1996). Purification and amino acid sequences of piscicocins V1a and V1b, two class IIa bacteriocins secreted by Carnobacterium piscicola V1 that display significantly different levels of specific inhibitory activity. Appl. Environ. Microbiol. 62, 4410-4416.

Bindiya, E. S., Tina, K. J., Raghul, S. S., and Bhat, S. G. (2015). Characterization of deep sea fish gut bacteria with antagonistic potential from Centroscyllium fabricii (deep sea shark). Prob. Antimicrob. Prot. 7, 157-163. doi: 10.1007/s12602-015-9190-x

Biswas, G., Korenaga, H., Nagamine, R., Takayama, H., Kawahara, S., Takeda, S., et al. (2013). Cytokine responses in the Japanese pufferfish (Takifugu rubripes) head kidney cells induced with heat-killed probiotics isolated from the Mongolian dairy products. Fish Shellfish Immunol. 34, 1170-1177. doi: 10.1016/j.fsi.2013.01.024

Boonanuntanasarn, S., Tiengtam, N., Pitaksong, T., Piromyou, P., and Teaumroong, N. (2017). Effects of dietary inulin and Jerusalem artichoke (Helianthus tuberosus) on intestinal microbiota community and morphology of Nile tilapia (Oreochromis niloticus) fingerlings. Aquacult. Nutr. 24, 712-722. doi: 10.1111/anu.12600

Bromage, E. S., Thomas, A., and Owens, L. (1999). Streptococcus iniae, a bacterial infection in barramundi Lates calcarifer. Dis. Aquat. Org. 36, 177-181. doi: 10.3354/dao036177

Bron, P. A., van Baarlen, P., and Kleerebezem, M. (2012). Emerging molecular insights into the interaction between probiotics and the host intestinal mucosa. Nat. Rev. Microbiol. 10, 66-78. doi: 10.1038/nrmicro2690

Brum, A., Pereira, S. A., Owatari, M. S., Chagas, E. C., Chaves, F. C. M., Mouriño, J. L. P., et al. (2017). Effect of dietary essential oils of clove basil and ginger on Nile tilapia (Oreochromis niloticus) following challenge with Streptococcus agalactiae. Aquaculture 468, 235-243. doi: 10.1016/j.aquaculture.2016.10.020

Bruni, L., Pastorelli, R., Viti, C., Gasco, L., and Parisi, G. (2018). Characterisation of the intestinal microbial communities of rainbow trout (Oncorhynchus mykiss) fed with Hermetia illucens (black soldier fly) partially defatted larva meal as partial dietary protein source. Acuaculture 487, 56-63. doi: 10.1016/j.aquaculture.2018.01.006

Burridge, L., Weis, J. S., Cabello, F., Pizarro, J., and Bostick, K. (2010). Chemical use in salmon aquaculture: a review of current practices and possible environmental effects. Aquaculture 306, 7-23. doi: 10.1016/j.aquaculture.2010.05.020

Cabello, F. C. (2006). Heavy use of prophylactic antibiotics in aquaculture: a growing problem for human and animal health and for the environment. Environ. Microbiol. 8, 1137-1144. doi: 10.1111/j.1462-2920.2006.01 054.x

Cai, X., Wang, B., Peng, Y., Li, Y., Lu, Y., Huang, Y., et al. (2017). Construction of a Streptococcus agalactiae phoB mutant and evaluation of its potential as an attenuated modified live vaccine in golden pompano, Trachinotus ovatus. Fish Shellfish Immunol. 63, 405-416. doi: 10.1016/j.fsi.2016.11.050

Cai, Y., Suyanandana, P., Saman, P., and Benno, Y. (1999). Classification and characterization of lactic acid bacteria isolated from the intestines of common carp and freshwater prawns. J. Gen. Appl. Microbiol. 45, 177-184. doi: 10.2323 /jgam.45.177 
Calo-Mata, P., Arlindo, S., Boehme, K., de Miguel, T., Pascoal, A., and BarrosVelazquez, J. (2007). Current applications and future trends of lactic acid bacteria and their bacteriocins for the biopreservation of aquatic food products. Food Biopro. Technol. 1, 43-63. doi: 10.1007/s11947-007-0021-2

Carnevali, O., Sun, Y.-Z., Merrifield, D. L., Zhou, Z., and Picchietti, S. (2014). "Probiotic applications in temperate and warm water fish species," in Aquaculture Nutrition: Gut Health, Probiotics and Prebiotics, eds D. Merrifield and E. Ringø (Oxford, UK: Wiley-Blackwell Publishing), 253-289.

Carr, F. J., Chill, D., and Maida, N. (2002). The lactic acid bacteria: a literature survey. Crit. Rev. Microbiol. 28, 281-370. doi: 10.1080/1040-840291 046759

Castex, M., Daniels, C., and Chim, L. (2014). "Probiotic applications in crustaceans," in Aquaculture Nutrition: Gut Health, Probiotics and Prebiotics, eds D. Merrifield and E. Ringø (Oxford, UK: Wiley-Blackwell Publishing), 290-327.

Chahad, O. B., El Bour, M., Calo-Mata, P., Boudabous, A., and Barros-Vela'zquez, J. (2012). Discovery of novel biopreservation agents with inhibitory effects on growth of food-borne pathogens and their application to seafood products. Res. Microbiol. 163, 44-54. doi: 10.1016/j.resmic.2011.08.005

Chen, S. C., Liaw, L. L., Su, H. Y., Ko, S. C., Wu, C. Y., Chaung, H. C., et al. (2002). Lactococcus garvieae, a cause of disease in grey mullet, Mugil cephalus L., in Taiwan. J. Fish Dis. 25, 727-732. doi: 10.1046/j.1365-2761.2002.00415.x

Choi, W. M., Lam, C. L., Mo, W. Y., Cheng, Z., Mak, N. K., Bian, Z. X., et al. (2014). Effects of the modified Huanglian Jiedu decoction on the disease resistance in grey mullet (Mugil cephalus) to Lactococcus garvieae. Mar. Poll. Bull. 85, 816-823. doi: 10.1016/j.marpolbul.2014.04.043

Collins, M. D., Ash, C., Farrow, J. A. E., Wallbanks, S., and Williams, A. M. (1989). $16 \mathrm{~S}$ ribosomal ribonucleic acid sequence analyses of lactococci and related taxa. Description of Vagococcus fluvialis gen. nov., sp. nov. J. Appl. Bacteriol. 67, 453 - 460. doi: 10.1111/j.1365-2672.1989.tb02516.x

Colorni, A., Diamant, A., Eldar, A., Kvitt, H., and Zlotkin, A. (2002). Streptococcus iniae infections in Red sea cage-cultured and wild fishes. Dis. Aquatic Org. 49, 165-170. doi: 10.3354/dao049165

Colorni, A., Ravelo, C., Romalde, J. L., Toranzo, A. E., and Diamant, A. (2003). Lactococcus garvieae in wild Red sea wrasse Coris aygula (Labridae). Dis. Aquat. Org. 56, 275-278. doi: 10.3354/dao056275

Cotter, P. D., Hill, C., and Ross, R. P. (2005). Bacteriocins: developing innate immunity for food. Nat. Rev. Microbiol. 3, 777-788. doi: 10.1038/nrmicro1273

Cotter, P. D., Ross, R. P., and Hill, C. (2013). Bacteriocins - a viable alternative to antibiotics? Nat. Rev. Microbiol. 11, 95-105. doi: 10.1038/nrmicro2937

Czaran, T. L., Hoekstra, R. F., and Pagie, L. (2002). Chemical warfare between microbes promotes biodiversity. Proc. Nat. Acad. Sci. U.S.A. 99, 786-790. doi: 10.1073/pnas.012399899

Dawood, M. A. O., and Koshio, S. (2016). Recent advances in the role of probiotics and prebiotics in carp aquaculture: a review. Aquaculture 454, 243-251. doi: 10.1016/j.aquaculture.2015.12.033

Dawood, M. A. O., Koshio, S., Ishikawa, M., El-Sabagh, M., Yokoyama, S., Wang, W.-L., et al. (2017). Physiological response, blood chemistry profile and mucus secretion of red sea bream (Pagrus major) fed diets supplemented with Lactobacillus rhamnosus under low salinity stress. Fish Physiol. Biochem. 43, 179-192. doi: 10.1007/s10695-016-0277-4

Dawood, M. A. O., Koshio, S., Ishikawa, M., and Yokoyama, S. (2015). Effects of heat killed Lactobacillus plantarum (LP20) supplemental diets on growth performance, stress resistance and immune response of red sea bream, Pagrus major. Aquaculture 442, 29-36. doi: 10.1016/j.aquaculture.2015. 02.005

Dawood, M. A. O., Koshio, S., Ishikawa, M., and Yokoyama, S. (2016a). Effects of dietary inactivated Pediococcus pentosaceus on growth performance, feed utilization and blood characteristics of red sea bream, Pagrus major juvenile. Aquacult. Nutr. 22, 923-932. doi: 10.1111/anu.12314

Dawood, M. A. O., Koshio, S., Ishikawa, M., Yokoyama, S., El Basuini, M. F., Hossain, M. S., et al. (2016b). Effects of dietary supplementation of Lactobacillus rhamnosus or/and Lactococcus lactis on the growth, gut microbiota and immune responses of red sea bream, Pagrus major. Fish Shellfish Immunol. 49, 275-285. doi: 10.1016/j.fsi.2015.12.047

De Kwaadsteniet, M., ten Doeschate, K., and Dicks, L. M. T. (2008). Characterization of the structural gene encoding nisin $\mathrm{f}$, a new lantibiotic produced by a Lactococcus lactis subsp. lactis isolate from freshwater catfish (Clarias gariepinus). Appl. Environ. Microbiol. 74, 547-549. doi: 10.1128/AEM.01862-07

De Vuyst, L., and Leroy, F. (2007). Bacteriocins from lactic acid bacteria: Production, purification and food applications. J. Mol. Microbiol. Biotechnol. 13, 194-199. doi: 10.1159/000104752

De, B. C., Meena, D., Behera, B., Das, P., Mohapatra, P. D., and Sharma, A. (2014). Probiotics in fish and shellfish culture: immunomodulatory and ecophysiological responses. Fish Physiol. Biochem. 40, 921-971. doi: 10.1007/s10695-13-9897-0.

Dehler, C. E., Secombes, C. J., and Martin, S. A. M. (2017a). Environmental and physiological factors shape the gut microbiota of Atlantic salmon parr (Salmo salar L.). Aquaculture 467, 149-157. doi: 10.1016/j.aquaculture.2016.07.017

Dehler, C. E., Secombes, C. J., and Martin, S. A. M. (2017b). Seawater transfer alters the intestinal microbiota profiles of Atlantic salmon parr (Salmo salar L.). Sci Rep. 7:13877. doi: 10.1038/s41598-017-13249-8

Del'Duca, A., Cesar, D. E., and Albreu, P. C. (2015). Bacterial community of pond's water, sediment and in the guts of tilapia (Oreochromis niloticus) juveniles characterized by fluorescent in situ hybridization technique. Aquacult Res. 46, 707-715. doi: 10.1111/are.12218

Delcenserie, V., Martel, D., Lamoureux, M., Amiot, J., Boutin, Y., and Roy, D. (2008). Immunomodulatory effects of probiotics in the intestinal tract. Curr. Issues Mol. Biol. 10, 37-54. doi: 10.21775/cimb.010.037

Desai, A. R., Links, M. G., Collins, S. A., Mansfield, G. S., Drew, M. D., Van Kessel, A. G., et al. (2012). Effects of plant based diets on the distal gut microbiome of rainbow trout (Oncorhynchus mykiss). Aquaculture 350-353, 134-142. doi: 10.1016/j.aquaculture.2012.04.005

Desriac, F., Defer, D., Bourgougnon, N., Brillet, B., Le Chevalier, P., and Fleury, Y. (2010). Bacteriocin as weapons in the marine animal-associated bacteria warfare: inventory and potential applications as an aquaculture probiotic. Mar. Drugs 8, 1153-1177. doi: 10.3390/md8041153

Didinen, B. I., Onuk, E. E., Metin, S., and Cayli, O. (2018). Identification and characterization of lactic acid bacteria isolated from rainbow trout (Oncorhynchus mykiss, Walbaum 1792), with inhibitory activity against Vagococcus salmoninarum and Lactococcus garvieae. Aquacult. Nutr. 24, 400-407. doi: 10.1111/anu.12571

Diop, M. B., Dubois-Dauphin, R., Destain, J., Tine, E., and Thonart, P. (2009). Use of a nisin-producing starter culture of Lactococcus lactis subsp, lactis to improve traditional fish fermentation in Senegal. J. Food Protect. 72, 1930-1934. doi: 10.4315/0362-028X-72.9.1930

do Vale Pereira, G., da Cunha, D. G., Mourino, J. L. P., Rodiles, A., JaramilloTorres, A., and Merrifield, D. L. (2017). Characterization of microbiota in Arapaima gigas intestine and isolation of potential probiotic bacteria. J. Appl. Microbiol. 123, 1298-1311. doi: 10.1111/jam.13572

Doan, H. V., Hoseinifar, S. H., Tapingkae, W., Chitmanat, C., and Mekchay, S. (2017). Effects of Cordyceps militaris spent mushroom substrate on mucosal and serum immune parameters, disease resistance and growth performance of Nile tilapia, (Oreochromis niloticus). Fish Shellfish Immunol. 67, 78-85. doi: 10.1016/j.fsi.2017.05.062

Dong, B., Yi, Y., Liang, L., and Shi, Q. (2017). High throughput identification of antimicrobial peptides from fish gastrointestinal microbiota. Toxins 9:266. doi: $10.3390 /$ toxins 9090266

Drider, D., Fimland, G., Hechard, Y., McMullen, L. M., and Prevost, H. (2006). The continuing story of class IIa bacteriocins. Microbiol. Mol. Biol. Rev. 70, 564-582. doi: 10.1128/MMBR.00016-05

DuPont, A. W., and DuPont, H. L. (2011). The intestinal microbiota and chronic disorders of the gut. Nat. Rev. Gastroenterol. Hepatol. 8, 523-531. doi: 10.1038/nrgastro.2011.133

Duremdez, R., Al-Marzouk, A., Qasem, J. A., Al-Harbi, A., and Gharabally, H. (2004). Isolation of Streptococcus agalactiae from cultured silver pomfret, Pampus argenteus (Euphrasen), in Kuwait. J. Fish Dis. 27, 307-310. doi: 10.1111/j.1365-2761.2004.00538.x

Eijsink, V. G. H., Axelsson, L., Diep, D. B., Havarstein, L. S., Holo, H., and Nes, I. F. (2002). Production of class II bacteriocins by lactic acid bacteria; an example of biological warfare and communication. Antonie Van Leeuwenhoek 81, 639-654. doi: 10.1023/A:1020582211262

Elayaraja, S., Annamalai, N., Mayavu, P., and Balasubramanian, T. (2014). Production, purification and characterization of bacteriocin from Lactobacillus 
murinus AU06 and its broad antibacterial spectrum. Asian Pac. J. Trop. Biomed. 4, S305-S311. doi: 10.12980/APJTB.4.2014C537

Evans, J. J., Klesius, P. H., and Shoemaker, C. A. (2004). Efficacy of Streptococcus agalactiae (group B) vaccine in tilapia (Oreochromis niloticus) by intraperitoneal and bath immersion administration. Vaccine 22, 3769-3773. doi: 10.1016/j.vaccine.2004.03.012

Evans, J. J., Klesius, P. H., and Shoemaker, C. A. (2009). First isolation and characterization of Lactococcus garvieae from Brazilian Nile tilapia, Oreochromis niloticus (L.), and pintado, Pseudoplathystoma corruscans (Spix \& Agassiz). J. Fish Dis. 32, 943-951. doi: 10.1111/j.1365-2761.2009.01075.x

Faikoh, E. N., Hong, Y.-H., and Hu, S.-Y. (2014). Liposome-encapsulated cinnamaldehyde enhances zebrafish (Danio rerio) immunity and survival when challenged with Vibrio vulnificus and Streptococcus agalactiae. Fish Shellfish Immunol. 38, 15-24. doi: 10.1016/j.fsi.2014.02.024

FAO/WHO (2002). Guidelines for the Evaluation of Probiotics in Food. Report of a joint FAO/WHO working group, London, ON.

Fečkaninová, A., Koščová, J., Mudronová, D., Popelka, P., and Toropilová, J. (2017). The use of probiotic bacteria against Aeromonas infections in salmonid aquaculture. Aquaculture 469, 1-8. doi: 10.1016j.aquaculture.2016. 11.042

Ford, A. C., Quigely, E. M. M., Lacy, B. E., Lembo, A. J., Saito, Y. A., Schiller, L. P., et al. (2014). Efficacy of prebiotics, probiotics, and synbiotics in irritable bowel syndrome and chronic idiopathic constipation: systematic review and meta-analysis. Am. J. Gastroenterol. 109, 1547-1561. doi: 10.1038/ajg.2014.202

Fukushima, H. C. S., Leal, C. A. G., Cavalcante, R. B., Figueiredo, H. C. P., Arijo, S., Morinigo, M. A., et al. (2017). Lactococcus garvieae outbreak in Brazilian farms lactococcosis in Pseudoplatystoma sp. - development of an autogenous vaccine as a control strategy. J. Fish Dis. 40, 263-272. doi: 10.1111/jfd. 12509

Fusco, V., Quero, G. M., Cho, G.-S., Kabisch, J., Meske, D., Neve, H., et al. (2015). The genus Weissella: taxonomy, ecology and biotechnological potential. Front. Microbiol. 6:155. doi: 10.3389/fmicb.2015.00155

Gabriel, N. N., Qiang, J., He, J., Ma, X. Y., Kpundeh, M. D., and Xu, P. (2015). Dietary aloe vera supplementation on growth performance, some haemato-biochemical parameters and disease resistance against Streptococcus iniae in tilapia (GIFT). Fish Shellfish Immunol. 44, 504-514. doi: 10.1016/j.fsi.2015.03.002

Gajardo, K., Jaramillo-Torres, A., Kortner, T. M., Merrifield, D. L., Tinsley, J., Bakke, A. M., et al. (2017). Alternative protein sources in the diet modulate microbiota and functionality in the distal intestine of Atlantic salmon (Salmo salar). Appl. Environ. Microbiol. 83:e02615. doi: 10.1128/AEM.02615-16

Ganguly, S., Dora, K. C., Sarkar, S., and Chowdhury, S. (2012). Supplementation of prebiotics in fish feed: a review. Rev. Fish Biol. Fish. 23, 195-199. doi: 10.1007/s11160-012-9291-5

Gao, Y., He, J., He, Z., Li, Z., Zhao, B., Mu, Y., et al. (2017). Effects of fulvic acid on growth performance and intestinal health of juvenile loach Paramisgurnus dabryanus (Sauvage). Fish Shellfish Immunol. 62, 47-56. doi: 10.1016/j.fsi.2017.01.008

Gatesoupe, F. J. (2008). Updating the importance of lactic acid bacteria in fish farming: natural occurrence and probiotic treatments. J. Mol. Microbiol. Biotechnol. 14, 107-114. doi: 10.1159/000106089

German, D. P. (2009). Inside the gut of wood-eating catfishes: can they digest wood? J. Comp. Physiol. B 179, 1011-1023. doi: 10.1007/s00360-0090381-1

Ghanbari, M., Jami, M., Kneifel, W., and Domig, K. J. (2013). Antimicrobial activity and partial characterization of bacteriocins produced by lactobacilli isolated from sturgeon fish. Food Control 32, 379-385. doi: 10.1016/j.foodcont.2012.12.024

Ghosh, S., Ringø, E., Selvam, A. D. G., Rahiman, K. M. M., Sathyan, N., John, N., et al. (2014). Gut associated lactic acid bacteria isolated from the estuarine fish Mugil cephalus: Molecular diversity and antibacterial activities against pathogens. Int. J. Aquacult. 4, 1-11. doi: 10.5376/ija.2014.04.0001

Gibson, G. R., and Roberfroid, M. B. (1995). Dietary modulation of the human colonic microbiota: introducing the concept of prebiotics. J. Nutr. 125, 1401-1412. doi: 10.1093/jn/125.6.1401

Gillor, O., Etzion, A., and Riley, M. A. (2008). The dual role of bacteriocins as anti- and probiotics. Appl. Microbiol. Biotechnol. 81, 591-606. doi: $10.1007 /$ s00253-008-1726-5
Gioacchini, G., Giorgini, E., Olivotto, I., Maradonna, F., Merrifield, D. L., and Carnevali, O. (2014). The influence of probiotics on zebrafish Danio rerio innate immunity and hepatic stress. Zebrafish 11, 98-106. doi: 10.1089/zeb.2013.0932

Giri, S. S., Sukumaran, V., and Oviya. (2013). Potential probiotic Lactobacillus plantarum VSG3 improves the growth, immunity, and disease resistance of tropical freshwater fish, Labeo rohita. Fish Shellfish Immunol. 34, 660-666. doi: 10.1016/j.fsi.2012.12.008

Giri, S. S., Sukumaran, V., Sen, S. S., and Jena, P. K. (2014). Effects of dietary supplementation of potential probiotic Bacillus subtilis VSG1 singularly or in combination with Lactobacillus plantarum VSG3 or/and Pseudomonas aeruginosa VSG2 on the growth, immunity and disease resistance of Labeo rohita. Aquacult. Nutr. 20, 163-171. doi: 10.1111/anu.12062

Gobbetti, M., De Angelis, M., Di Cagno, R., Minervini, F., and Limitone, A. (2007) Cell-cell communication in food related bacteria. Int. J. Food Microbiol. 120, 34-45. doi: 10.1016/j.ijfoodmicro.2007.06.012

Gomez, D., Sunyer, J. O., and Salinas, I. (2013). The mucosal immune system of fish: the evolution of tolerating commensals while fighting pathogens. Fish Shellfish Immunol. 35, 1729-1739. doi: 10.1016/j.fsi.2013.09.032

Gómez, G. D., and Balcázar, J. L. (2008). A review on the interactions between gut microbiota and innate immunity of fish. FEMS Immunol. Med. Microbiol. 52, 145-154. doi: 10.1111/j.1574-695X.2007.00343.x

Gómez-Sala, B., Munoz-Atienza, E., Sánchez, J., Basanta, A., Herranz, C. Hernández, P. E., et al. (2015). Bacteriocin production by lactic acid bacteria isolated from fish, seafood and fish products. Eur. Food Res. Technol. 241, 341-356. doi: 10.1007/s00217-015-2465-3

González, C. J., Encinas, J. P., García-López, M. L., and Otero, A. (2000). Characterization and identification of lactic acid bacteria from freshwater fishes. Food Microbiol. 17, 383 - 391. doi: 10.1006/fmic.1999.0330

Gudding, R., and Van-Muiswinkel, W. B. (2013). A history of fish vaccination science-based disease prevention in aquaculture. Fish Shellfish Immunol. 35, 1683-1688. doi: 10.1016/j.fsi.2013.09.031

Guerreiro, I., Serra, C. R., Oliva-Teles, A., and Enes, P. (2018b). Short communication: gut microbiota of European sea bass (Dicentrarchus labrax) is modulated by short-chain fructooligosaccharides and xylooligosaccharides. Aquacult. Int. 26, 279-288. doi: 10.1007/s10499-017-0220-4

Guerreiro, I., Serra, C. R., Pousão-Ferreira, P., Oliva-Teles, A., and Enes, P. (2018a). Prebiotics effect on growth performance, hepatic intermediary metabolism, gut microbiota and digestive enzymes of white sea bream (Diplodus sargus). Aquacult. Nutr. 24, 153-163. doi: 10.1111/anu.12543

Guimarães, I. G., Lim, C., Yildirim-Aksoy, M., Li, M. H., and Klesius, P. H. (2014) Effects of dietary levels of vitamin A on growth, hematology, immune response and resistance of Nile tilapia (Oreochromis niloticus) to Streptococcus iniae. Anim. Feed Sci. Technol. 188, 126-136. doi: 10.1016/j.anifeedsci.2013.12.003

Gutowska, M. A., Drazen, J. C., and Robison, B. H. (2004). Digestive chitinolytic activity in marine fishes of Monterey bay, California. Comp. Biochem. Physiol. Part A 13, 351-358. doi: 10.1016/j.cbpb.2004.09.020

Haines, A. N., Gauthier, D. T., Nebergall, E. E., Cole, S. D., Nguyen, K. M., Rhodes, M. W., et al. (2013). First report of Streptococcus parauberis in wild finfish from North America. Vet Microbiol. 166, 270-275. doi: 10.1016/j.vetmic.2013.05.002

Halami, P. M., Chandrashekar, A., and Joseph, R. (1999). Characterization of bacteriocinogenic strains of lactic acid bacteria in fowl and fish intestine and mushroom. Food Biotechnol. 13, 121-136. doi: 10.1080/08905439909549966

Hammami, R., Zouhir, A., Le Lay, C., Ben Hamida, J., and Fliss, I. (2010). BACTIBASE second release: a database and tool platform for bacteriocin characterization. BMC Microbiol. 10:22. doi: 10.1186/1471-2180-10-22

Harikrishnan, R., Kim, M.-C., Kim, J.-S., Balasundaram, C., and Heo, M.S. (2011). Protective effect of herbal and probiotics enriched diet on haematological and immunity status of Oplegnathus fasciatus (Temminck \& Schlegel) against Edwardsiella tarda. Fish Shellfish Immunol. 30, 886-893. doi: 10.1016/j.fsi.2011.01.013

He, R.-P., Feng, J., Tian, X.-L., Dong, S.-L., and Wen, B. (2017). Effects of dietary supplementation of probiotics on the growth, activities of digestive and non-specific immune enzymes in hybrid grouper (Epinephelus lanceolatus $\sigma^{7} \times$ Epinephelus fuscoguttatus o). Aquacult. Res. 48, 5782-5790. doi: 10.1111/are.13401

Heo, W. S., Kim, E. Y., Kim, Y. R., Hossain, M. T., and Kong, I. S. (2012). Salt effect of nisin $\mathrm{Z}$ isolated from a marine fish on the growth inhibition of 
Streptococcus iniae, a pathogen of streptococcosis. Biotechnol. Lett. 34, 315-320. doi: 10.1007/s10529-011-0766-6

Hiu, S. F., Holt, R. A., and Sriranganathan, N. (1984). Lactobacillus piscicola, a new species from salmonid fish. Int. J. Syst. Bacteriol. 34, 393-400. doi: 10.1099/00207713-34-4-393

Hoseinifar, S. H., Hoseini, S. M., and Bagheri, D. (2016b). Effects of galactooligosaccharide and Pediococcus acidilactici on antioxidant defence and disease resistance of rainbow trout, Oncorhynchus mykiss. Ann. Anim. Sci. 17, 217-227. doi: 10.1515/aoas-2016-0024

Hoseinifar, S. H., Khalili, M., and Sun, Y.-Z. (2016a). Intestinal histomorphology, autochthonus microbiota and growth performance of the oscar (Astronotus ocellatus Agassiz, 1831) following dietary administration of xylooligosaccharide. J. Ichthyol. 32, 1137-1141. doi: 10.1111/jai.13118

Hoseinifar, S. H., Mirvaghefi, A., Amoozegar, M. A., Merrifield, D., and Ringø, E. (2015a). In vitro selection of a synbiotic and in vivo evaluation on intestinal microbiota, performance and physiological response of rainbow trout (Oncorhynchus mykiss) fingerlings. Aquacult. Nutr. 23, 111-118. doi: $10.1111 /$ anu.12373.

Hoseinifar, S. H., Mirvaghefi, A., Amoozegar, M. A., Sharifian, M., and Esteban, M. Á. (2015b). Modulation of innate immune response, mucosal parameters and disease resistance in rainbow trout (Oncorhynchus mykiss) upon synbiotic feeding. Fish Shellfish Immunol. 45, 27-32. doi: 10.1016/j.fsi.2015.03.029

Hoseinifar, S. H., Ringø, E., Shenavar Masouleh, A., and Esteban, M. Á. (2016c). Probiotic, prebiotic and synbiotic supplements in sturgeon aquaculture: a review. Rev. Aquacult. 8, 89-102, doi: 10.1111/raq.12082

Hoseinifar, S. H., Roosta, Z., Hajimoradloo, A., and Vakili, F. (2015c). The effects of Lactobacillus acidophilus as feed supplement on skin mucosal immune parameters, intestinal microbiota, stress resistance and growth performance of black swordtail (Xiphophorus helleri). Fish Shellfish Immunol. 42, 533-538. doi: 10.1016/j.fsi.2014.12.003

Hoseinifar, S. H., Safari, R., and Dadar, M. (2017). Dietary sodium propionate affects mucosal immune parameters, growth and appetite related genes expression: Insights from zebrafish model. Gen. Comp. Endocrinol. 243, 78-83. doi: 10.1016/j.ygcen.2016.11.008

Hosseini, M., Miandare, H. K., Hoseinifar, S. H., and Yarahmadi, P. (2016). Dietary Lactobacillus acidophilus modulated skin mucus protein profile, immune and appetite genes expression in gold fish (Carassius auratus gibelio). Fish Shellfish Immunol. 59, 149-154. doi: 10.1016/j.fsi.2016.10.026

Huang, J.-B., Wu, Y.-C., and Chi, S.-C. (2014). Dietary supplementation of Pediococcus pentosaceus enhances innate immunity, physiological health and resistance to Vibrio anguillarum in orange-spotted grouper (Epinephelus coioides). Fish Shellfish Immunol. 39, 196-205. doi: 10.1016/j.fsi.2014. 05.003

Huang, L. Y., Wang, K. Y., Xiao, D., Chen, D. F., Geng, Y., Wang, J., et al. (2014). Safety and immunogenicity of an oral DNA vaccine encoding Sip of Streptococcus agalactiae from Nile tilapia Oreochromis niloticus delivered by live attenuated Salmonella typhimurium. Fish Shellfish Immunol. 38, 34-41. doi: 10.1016/j.fsi.2014.02.017

Huyben, D., Nyman, A., Vidakovi'c, A., Passoth, V., Moccia, R., Kiessling, A., et al. (2017). Effects of dietary inclusion of the yeast Saccharomyces cerevisiae and Wickerhamomyces anomalus on gut microbiota of rainbow trout. Aquaculture 473, 528-537, doi: 10.1016/j.aquaculture.2017.03.024

Huyben, D., Sun, L., Moccia, R., Kiessling, A., Dicksved, J., and Lundh, T. (2018). Dietary live yeast and increased water temperature influence the gut microbiota of rainbow trout. J. Appl. Microbiol. 124, 1377-1392. doi: 10.1111/jam. 13738

Indira, K., Jayalakshmi, S., Gopalakrishnan, A., and Srinivasan, M. (2011). Biopreservative potential of marine Lactobacillus spp. Afr. J. Microbiol. Res. 5, 2287-2296. doi: 10.5897/AJMR11.613

Irianto, A., and Austin, B. (2002). Probiotics in aquaculture. J. Fish Dis. 25, 63-642. doi: 10.1046/j.1365-2761.2002.00422.x

Issazadeh, K., Pahlaviani, M., and Massiha, A. (2012). "Isolation of Lactobacillus species from sediments of Caspian sea for bacteriocin production," in 2nd Int Con. Biomed. Eng. Tech IPCBEE (Singapore), 79-84.

Iwashita, M. K., Nakandakare, I. B., Terhune, J. S., Wood, T., and RanzaniPaiva, M. J. (2015). Dietary supplementation with Bacillus subtilis, Saccharomyces cerevisiae and Aspergillus oryzae enhance immunity and disease resistance against Aeromonas hydrophila and Streptococcus iniae infection in juvenile tilapia Oreochromis niloticus. Fish Shellfish Immunol. 43, 60-66. doi: 10.1016/j.fsi.2014.12.008

Jesus, G., Vieira, F., Silva, B., Junior, M., Ushizima, T., Schmidt, E., et al. (2017). Probiotic bacteria may prevent haemorrhagic septicaemia by maturing intestinal host defences in Brazilian native surubins. Aquacult. Nutr. 23, 484-491. doi: 10.1111/anu.12416

Kaew-on, S., Areechon, N., and Wanchaitanawong, P. (2016). Effects of Pediococcus pentosaceus PKWA-1 and Bacillus subtilis BA04 on growth performances, immune responses and disease resistance against Aeromonas hydrophila in Nile Tilapia (Oreochromis niloticus Linn.). Chiang Mai J. Sci. 43, 997-1006. Available online at: http://it.science.cmu.ac.th/ejournal/ journalDetail.php?journal_id=7358

Kane, A. M., Soltani, M., Ebrahimzahe-Mousavi, H. A., and Pakzad, K. (2016). Influence of probiotic, Lactobacillus plantarum on serum biochemical and immune parameters in vaccinated rainbow trout (Oncorhynchus mykiss) against streptococcosis/lactococosis. Int J. Aquat. Biol. 4, 285-294. doi: 10.22034/ijab.v4i4.226

Karthikeyan, V., and Santhosh, S. W. (2009). Study of bacteriocin as a food preservative and the L. acidophilus strain as probiotic. Pakistan J. Nutr. 8, 335-340. doi: 10.3923/pjn.2009.335.340

Kawanishi, M., Kojima, A., Ishihara, K., Esaki, H., Kijima, M., Takahashi, T., et al. (2005). Drug resistance and pulsed-field gel electrophoresis patterns of Lactococcus garvieae isolates from cultured seriola (yellowtail, amberjack and kingfish) in Japan. Lett. Appl. Microbiol. 40, 322-328. doi: 10.1111/j.1472-765X.2005.01690.x

Kayansamruaj, P., Dong, H. T., Pirarat, N., Nilubol, D., and Rodkhum, C. (2017). Efficacy of $\alpha$-enolase-based DNA vaccine against pathogenic Streptococcus iniae in Nile tilapia (Oreochromis niloticus). Aquaculture 468, 102-106. doi: 10.1016/j.aquaculture.2016.10.001

Ke, X., Chen, X., Liu, Z., Lu, M., Gao, F., and Cao, J. (2017). Immunogenicity of the LrrG protein encapsulated in PLGA microparticles in Nile tilapia (Oreochromis niloticus) vaccinated against Streptococcus agalactiae. Aquaculture 480, 51-57. doi: 10.1016/j.aquaculture.2017.08.003

Kesarcodi-Watson, A., Kaspar, H., Lategan, M. J., and Gibson, L. (2008). Probiotics in aquaculture: the need, principles and mechanisms of action and screening processes. Aquaculture 274, 1-14. doi: 10.1016/j.aquaculture.2007.11.019

Kim, D. H., and Austin, B. (2008). Characterization of probiotic carnobacteria isolated from rainbow trout (Oncorhynchus mykiss) intestine. Lett. Appl. Microbiol. 47, 141-147. doi: 10.1111/j.1472-765X.2008.02401.x

Kim, D., Beck, B. R., Heo, S.-B., Kim, J., Kim, H. D., Lee, S.-M., et al. (2013). Lactococcus lactis BFE920 activates the innate immune system of olive flounder (Paralichthys olivaceus), resulting in protection against Streptococcus iniae infection and enhancing feed efficiency and weight gain in large-scale field studies. Fish Shellfish Immunol. 35, 1585-1590. doi: 10.1016/j.fsi.2013.09.008

Kim, D., Beck, B. R., Lee, S. M., Jeon, J., Lee, D. W., Lee, J. I., et al. (2016). Pellet feed adsorbed with the recombinant Lactococcus lactis BFE920 expressing SiMA antigen induced strong recall vaccine effects against Streptococcus iniae infection in olive flounder (Paralichthys olivaceus). Fish Shellfish Immunol. 55, 374-383. doi: 10.1016/j.fsi.2016.06.010

Kim, Y.-R., Kim, E.-Y., Choi, S.-Y., Hossain, M. T., Oh, R., Heo, W.-S., et al. (2012). Effect of a probiotic strain, Enterococcus faecium, on the immune responses of olive flounder (Paralichthys olivaceus). J. Microbiol. Biotechnol. 22, 526-529. doi: $10.4014 / j m b .1108 .08047$

Klaenhammer, T. R. (1993). Genetics of bacteriocins produced by lactic acid bacteria. FEMS Microbiol. Lett. 12, 224-227. doi: 10.1111/j.1574-6976.1993.tb00012.x

Klesius, P. H., Shoemaker, C. A., and Evans, J. J. (2000). Efficacy of single and combined Streptococcus iniae isolate vaccine administered by intraperitoneal and intramuscular routes in tilapia (Oreochromis niloticus). Aquaculture 188, 237-246. doi: 10.1016/S0044-8486(00)00345-8

Knosp, C. A., and Johnston, J. A. (2012). Regulation of CD4 ${ }^{+}$T-cell polarization by suppressor of cytokine signaling proteins. Immunology 135, 101-111. doi: 10.1111/j.1365-2567.2011.03520.x

Kolndadacha, O. D., Adikwu, I. A., Okaeme, A. N., Atiribom, R. Y., Mohammed, A., and Musa, Y. M. (2011). The role of probiotics in aquaculture in Nigeria - a review. Cont. J. Fish Aquat. Sci. 5, 8-15. Available online at: http://www. wiloludjournal.com 
Kraus, H. (1961). Kurze mitteilung über das vorkommen von Lactobazillien auf fischen heringen. Arch. Lebensmittelhyg. 12, 101-102.

Kumar, S. R., and Arul, V. (2009). Purification and characterization of phocaecin PI80: an anti-listerial bacteriocin produced by Streptococcus phocae PI80 Isolated from the gut of Peneaus indicus (Indian white shrimp). J. Microbiol. Biotechnol. 19, 1393-1400. doi: 10.4014/jmb.0901.0003

Kusuda, R., and Salati, F. (1993). Major bacterial diseases affecting mariculture in Japan. Ann. Rev. Fish Dis. 3, 69-85. doi: 10.1016/0959-8030(93)90029-B

Lagha, A. B., Haas, B., Gottschalk, M., and Grenier, D. (2017). Antimicrobial potential of bacteriocins in poultry and swine production. Vet Res. 48:22. doi: 10.1186/s13567-017-0425-6

Laing, K. J., and Hansen, J. D. (2011). Fish T cells: recent advances through genomics. Dev. Comp. Immunol. 35, 1282-1295. doi: 10.1016/j.dci.2011.03.004

Laith, A. A., Mazlan, A. G., Effendy, A. W., Ambak, M. A., Nurhafizah, W. W. I., Alia, A. S., et al. (2017). Effect of Excoecaria agallocha on non-specific immune responses and disease resistance of Oreochromis niloticus against Streptococcus agalactiae. Res. Vet. Sci. 112, 192-200. doi: 10.1016/j.rvsc.2017.04.020

Lauzon, H. L., Dimitroglou, A., Merrifield, D. L., Ringø, E., and Davies, S. J. (2014). "Probiotics and prebiotics: concepts, definitions and history," in Aquaculture Nutrition: Gut Health, Probiotics and Prebiotics, eds D. Merrifield and E. Ringø (Oxford, UK: Wiley-Blackwell Publishing), 169-184.

Lauzon, H. L., and Ringø, E. (2011). "Prevalence and application of lactic acid bacteria in aquatic environments," in Lactic Acid Bacteria: Microbiological and Functional Aspects, 4th Edn, eds S. Lahtinen, A. Ouwehand, S. Salminen, and A. von Wright (New York, NY: CRC Press, Taylor and Francis Group), 593-631.

Lavoie, C., Courcelle, M., Redivo, B., and Derome, N. (2018). Structural and compositional mismatch between captive and wild Atlantic salmon (Salmo salar) parrs gut microbiota highlights the relevance of integrating molecular ecology for management and conservation methods. Evolution. Appl. doi: $10.1111 /$ eva.12652

Lee, S., Katya, K., Park, Y., Won, S., Seong, M., Hamidoghli, A., et al. (2017). Comparative evaluation of dietary probiotics Bacillus subtilis WB60 and Lactobacillus plantarum KCTC3928 on the growth performance, immunological parameters, gut morphology and disease resistance in Japanese eel, Anguilla japonica. Fish Shellfish Immunol. 61, 201-210. doi: $10.1016 /$ j.fsi.2016.12.035

Leisner, J. J., Groth Laursen, B. G., Prévost, H., Drider, D., and Dalgaard, P. (2007). Carnobacterium: positive and negative effects in the environment and in foods. FEMS Microbiol Rev. 31, 592-613. doi:10.1111/j.1574-6976.2007. 00080.x

Leisner, J. J., Hansen, M. A., Larsen, M. H., Hansen, L., Ingmer, H., and Sørensen, S. J. (2012). The genome sequence of the lactic acid bacterium, Carnobacterium maltaromaticum ATCC 35586 encodes potential virulence factors. Int. J. Food Microbiol. 152, 107-115. doi: 10.1016/j.ijfoodmicro.2011.05.012

Lescak, E. A., and Milligan, K. C. (2017). Teleost as model organisms to understand host-microbe interactions. J. Bacteriol. 199, e00868-16. doi: 10.1128/JB.00868-16

Li, H., Zhong, Q.,Wirth, S., Wang, W., Hao, Y., Zou, H., et al. (2015). Diversity of autochthonous bacterial communities in the intestinal mucosa of grass carp (Ctenopharyngodon idellus) (Valenciennes) by culture-dependent and cultureindependent techniques. Aquacult. Res. 46, 2344-2359. doi: 10.1111/are.12391

Li, P., and Gatlin, D. M. III. (2004). Dietary brewers yeast and the prebiotic Grobiotic ${ }^{\mathrm{TM}} \mathrm{AE}$ influence growth performance, immune responses and resistance of hybrid striped bass (Morone chrysops $\times M$. saxatilis) to Streptococcus iniae infection. Aquaculture 231, 445-456. doi: 10.1016/j.aquaculture.2003.08.021

Li, P., Lewis, D. H., and Gatlin, D. M. (2004). Dietary oligonucleotides from yeast RNA influence immune responses and resistance of hybrid striped bass (Morone chrysops $\times$ Morone saxatilis) to Streptococcus iniae infection. Fish Shellfish Immunol. 16, 561-569. doi: 10.1016/j.fsi.2003. 09.005

Li, X., Ringø, E., Hoseinifar, S. H., Lauzon, H., Birkbeck, H., and Yang, D. (2018). Adherence and colonisation of microorganisms in the fish gastrointestinal tract. Rev Aquacult. doi: 10.1111/raq.12248

Lim, C., Yildirim-Aksoy, M., Li, M. H., Welker, T. L., and Klesius, P. H. (2009). Influence of dietary levels of lipid and vitamin $\mathrm{E}$ on growth and resistance of Nile tilapia to Streptococcus iniae challenge. Aquaculture 298, 76-82. doi: 10.1016/j.aquaculture.2009.09.025
Lin, Y. H., Chen, Y. S., Wu, H. C., Pan, S. F., Yu, B., Chiang, C. M., et al. (2012). Screening and characterization of LAB-produced bacteriocin-like substances from the intestine of grey mullet (Mugil cephalus L.) as potential biocontrol agents in aquaculture. J. Appl. Microbiol. 114, 299-307. doi: 10.1111/jam. 12041

Lisboa, M. P., Bonatto, D., Bizani, D., Henriques, J. A. P., and Brandelli, A. (2006). Characterization of a bacteriocin-like substance produced by Bacillus amyloliquefaciens isolated from the Brazilian Atlantic Forest. Int. Microbiol. 9, 111-118. Available online at: www.im.microbios.org

Liu, H., Wang, S., Cai, Y., Guo, X., Cao, Z., Zhang, Y., et al. (2017). Dietary administration of Bacillus subtilis HAINUP40 enhances growth, digestive enzyme activities, innate immune responses and disease resistance of tilapia, Oreochromis niloticus. Fish Shellfish Immunol. 60, 326-333. doi: 10.1016/j.fsi.2016.12.003

Liu, L., Li, Y. W., He, R. Z., Xiao, X. X., Zhang, X., Su, Y. L., et al. (2014). Outbreak of Streptococcus agalactiae infection in barcoo grunter, Scortum barcoo (McCulloch \& Waite), in an intensive fish farm in China. J. Fish Dis. 37, 1067-1072. doi: 10.1111/jfd.12187

Liu, W., Ren, P., He, S., Xu, L., Yang, Y., Gu, Z., et al. (2013). Comparison of adhesive gut bacteria composition, immunity, and disease resistance in juvenile hybrid tilapia fed two different Lactobacillus strains. Fish Shellfish Immunol. 35, 54-62. doi: 10.1016/j.fsi.2013.04.010

Liu, W., Wang, W., Ran, C., He, S., Yang, Y., and Zhou, Z. (2017). Effects of dietary scFOS and lactobacilli on survival, growth, and disease resistance of hybrid tilapia. Aquaculture 470, 50-55. doi: 10.1016/j.aquaculture.2016. 12.013

Loch, T. P., Xu, W., Fitzgerald, S. M., and Faisal, M. (2008). Isolation of a Carnobacterium maltaromaticum-like bacterium from systemically infected lake whitefish (Coregonus clupeaformis). FEMS Microbiol. Lett. 288, 76-84. doi: 10.1111/j.1574-6968.2008.01338.x

Lopez Cazorla, A., Sica, M. G., Brugnoni, L. I., Marucci, P. L., and Cubitto, M. A. (2015). Evaluation of Lactobacillus paracasei subsp. tolerans isolated from Jenyn's sprat (Ramnogaster arcuata) as probiotic for juvenile rainbow trout Oncorhynchus mykiss (Walbaum, 1792). J. Appl. Ichthyol. 31, 88-94. doi: 10.1111/jai.12496

Luo, X., Fu, X., Liao, G., Chang, O., Huang, Z., and Li, N. (2017). Isolation, pathogenicity and characterization of a novel bacterial pathogen Streptococcus uberis from diseased mandarin fish Siniperca chuatsi. Microb. Pathogen. 107, 380-389. doi: 10.1016/j.micpath.2017.03.049

Lyons, P. P., Turnbull, J. F., Dawson, K. A., and Crumlish, M. (2016). Phylogenetic and functional characterization of the distal intestine microbiome of rainbow trout Oncorhynchus mykiss from both farm and aquarium settings. J. Appl. Microbiol. 122, 347-363. doi: 10.1111/jam.13347

Lyons, P. P., Turnbull, J. F., Dawson, K. A., and Crumlish, M. (2017a). Exploring the microbial diversity of the distal lumen and mucosa of farmed rainbow trout Oncorhynchus mykiss (Walbaum) using next generation sequencing (NGS). Aquacult Res. 48, 77-91. doi: 10.1111/are.12863

Lyons, P. P., Turnbull, J. F., Dawson, K. A., and Crumlish, M. (2017b). Effects of low-level dietary microalgae supplementation on the distal intestine microbiome of farmed rainbow trout Oncorhynchus mykiss (Walbaum). Aquacult. Res. 48, 2438-2452. doi: 10.1111/are.13080

Ma, Y.-P., Ke, H., Liang, Z.-L., Ma, J.-Y., Hao, L., and Liu, Z.-X. (2017). Protective efficacy of cationic-PLGA microspheres loaded with DNA vaccine encoding the sip gene of Streptococcus agalactiae in tilapia. Fish Shellfish Immunol. 66, 345-353. doi: 10.1016/j.fsi.2017.05.003

Maiuta, N. D., Schwarzentruber, P., Schenker, M., and Schoelkopf, J. (2013). Microbial population dynamics in the faeces of wood-eating loricariid catfishes. Lett. Appl. Microbiol. 56, 401-407, doi: 10.1111/lam.12061

Maji, U. J., Mohanty, S., Pradhan, A., and Maiti, N. K. (2017). Immune modulation, disease resistance and growth performance of Indian farmed carp, Labeo rohita (Hamilton), in response to a dietary consortium of putative lactic acid bacteria. Aquacult. Int. 25, 1391-1407. doi: 10.1007/s10499-017-0122-5

Marisa Halim, A., Lee, P.-P., Chang, Z.-W., and Chang, C.-C. (2017). The hot-water extract of leaves of noni, Morinda citrifolia, promotes the immunocompetence of giant freshwater prawn, Macrobrachium rosenbergii. Fish Shellfish Immunol. 64, 457-468. doi: 10.1016/j.fsi.2017.03.045

Martinez, F. O., and Gordon, S. (2014). The M1 and M2 paradigm of macrophage activation: time for reassessment. F1000prime Rep. 6:13. doi: 10.12703/P6-13 
Martins, M., Mouriño, J., Amaral, G., Vieira, F., Dotta, G., Jatobá, A., et al. (2008). Haematological changes in Nile tilapia experimentally infected with Enterococcus sp. Braz. J. Biol. 68, 657-661. doi: 10.1590/S1519-69842008000300025

Matsuura, Y., Takasaki, M., Miyazawa, R., and Nakanishi, T. (2017). Stimulatory effects of heat-killed Enterococcus faecalis on cell-mediated immunity in fish. Dev. Comp. Immunol. 74, 1-9. doi: 10.1016/j.dci.2017.03.029

Merrifield, D. L., Balcázar, J. L., Daniels, C., Zhou, Z., Carnevali, O., Sun, Y.-Z., et al. (2014). "Indigenous lactic acid bacteria in fish and crustaceans," in Aquaculture Nutrition: Gut Health, Probiotics and Prebiotics, eds D. Merrifield and E. Ringø (Oxford, UK: Wiley-Blackwell Publishing), 128-168.

Meyburgh, C. M., Bragg, R. R., and Boucher, C. E. (2017). Lactococcus garvieae: an emerging bacterial pathogen of fish. Dis. Aquatic. Org. 123, 67-79. doi: $10.3354 /$ dao03083

Miao, S., Zhao, C., Zhu, J., Hu, J., Dong, X., and Sun, L. (2018). Dietary soybean meal affects intestinal homoeostasis by altering the microbiota, morphology and inflammatory cytokine gene expression in northern snakehead. Sci. Rep. 8:113. doi: 10.1038/s41598-017-18430-7

Michel, C., Faivre, B., and Kerouault, B. (1986). Biochemical identification of Lactobacillus piscicola strains from France and Belgium. Dis. Aquatic. Org. 2, 27-30. doi: 10.3354/dao002027

Michel, C., Pelletier, C., Boussaha, M., Douet, D. G., Lautraite, A., and Tailliez, P. (2007). Diversity of lactic acid bacteria associated with fish and the farm environment, established by amplified rRNA gene restriction analysis. Appl. Environ. Microbiol. 73, 2947-2955. doi: 10.1128/AEM.01852-06

Mirzapour-Rezaee, S., Farhangi, M., and Rafiee, G. (2017). Combined effects of dietary mannan- and fructo-oligosaccharide on growth indices, body composition, intestinal bacterial flora and digestive enzymes activity of regal peacock (Aulonocara stuartgranti). Aquacult. Nutr. 23, 629-636. doi: $10.1111 /$ anu. 12430

Modanloo, M., Soltanian, S., Akhlaghi, M., and Hoseinifar, S. H. (2017). The effects of single or combined administration of galactooligosaccharide and Pediococcus acidilactici on cutaneous mucus immune parameters, humoral immune responses and immune related genes expression in common carp (Cyprinus carpio) fingerlings. Fish Shellfish Immunol. 70, 391-397. doi: 10.1016/j.fsi.2017.09.032

Mohammadian, T., Alishahi, M., Tabande, M., Ali, Z., and Nejad, A. (2017). Effect of different levels of Lactobacillus casei on growth performance and digestive enzymes activity of shirbot (Barbus gryprus). J. Vet. Res. 72, 43-52.

Mohammadian, T., Alishahi, M., Tabandeh, M. R., Ghorbanpoor, M., Gharibi, D., Tollabi, M., et al. (2016). Probiotic effects of Lactobacillus plantarum and L. delbrueckii ssp. bulguricus on some immune-related parameters in Barbus grypus. Aquacult. Int. 24, 225-242. doi: 10.1007/s10499-015-9921-8

Mokoena, M. P. (2017). Lactic acid bacteria and their bacteriocins: Classification, biosynthesis and applications against uropathogens: a mini-review. Molecules 22, 1255. doi: 10.3390/molecules22081255

Moslehi, F., Sattari, M., and Masouleh, A. S. (2016). Effects of Pediococcus pentosaceus as a probiotic on intestinal microbiota and body composition of Siberian sturgeon, Acipenser baerii Brandt, 1869. Int. J. Aquatic. Biol. 4, 11-16. doi: $10.22034 /$ ijab.v4i1.117

Mukherjee, A., Dutta, D., Banerjee, S., Ringø, E., Breines, E. M., Hareide, E., et al. (2016). Potential probiotics from Indian major carp, Cirrhinus mrigala. Characterization, pathogen inhibitory activity, partial characterization of bacteriocin and production of exoenzymes. Res. Vet. Sci. 108, 76-84. doi: 10.1016/j.rvsc.2016.08.011

Munoz-Atienza, E., Araújo, C., Lluch, N., Hernández, P. E., Herranz, C., Cintas, L. M., et al. (2015). Different impact of heat-inactivated and viable lactic acid bacteria of aquatic origin on turbot (Scophthalmus maximus L.) head-kidney leucocytes. Fish Shellfish Immunol. 44, 214-223. doi: 10.1016/j.fsi.2015.02.021

Muñoz-Atienza, E., Gómez-Sala, B., Araújo, C., Campanero, C., del Campo, R., Hernández, P. E., et al. (2013). Antimicrobial activity, antibiotic susceptibility and virulence factors of lactic acid bacteria of aquatic origin intended for use as probiotics in aquaculture. BMC Microbiol. 13:15. doi: 10.1186/1471-2180-13-15

Musa, N., Wei, L. S., Musa, N., Hamdan, R. H., Leong, L. K., Wee, W., et al. (2009). Streptococcosis in red hybrid tilapia (Oreochromis niloticus) commercial farms in Malaysia. Aquacult. Res. 40, 630-632. doi: 10.1111/j.1365-2109.2008.02142.x

Nayak, S. K. (2010). Probiotics and immunity: A fish perspective. Fish Shellfish Immunol. 29, 2-14. doi: 10.1016/j.fsi.2010.02.017
Neissi, A., Rafiee, G., Nematollahi, M., and Safari, O. (2013). The effect of Pediococcus acidilactici bacteria used as probiotic supplement on the growth and non-specific immune responses of green terror, Aequidens rivulatus. Fish Shellfish Immunol. 35, 1976-1980, doi: 10.1016/j.fsi.2013.09.036

Neuman, C., Hatje, E., Zarkasi, K., Smullen, R., Bowman, J. P., and Katouli, M. (2015). The effect of diet and environmental temperature on faecal microbiota of farmed Tasmanian Atlantic salmon (Salmo salar L.). Aquacult Res. 47, 660-672. doi: 10.1111/are.12522

Newaj-Fyzul, A., and Austin, B. (2014). Probiotics, immunostimulants, plant products and oral vaccines, and their role as feed supplements in the control of bacterial fish diseases. J. Fish Dis. 38, 937-955. doi: 10.1111/jfd.12313

Ng, W. K., Kim, Y. C., Romano, N., Koh, C. B., and Yang, S. Y. (2014). Effects of dietary probiotics on the growth and feeding efficiency of red hybrid tilapia, Oreochromis sp., and subsequent resistance to Streptococcus agalactiae. J. Appl. Aquacult. 26, 22-31. doi: 10.1080/10454438.2013.874961

Nguyen, H. T., Kanai, K., and Yoshikoshi, K. (2002). Ecological investigation of Streptococcus iniae in cultured Japanese flounder (Paralichthys olivaceus) using selective isolation procedures. Aquaculture 205, 7-17. doi: 10.1016/S0044-8486(01)00667-6

Nguyen, T. L., Park, C.-I., and Kim, D.-H. (2017). Improved growth rate and disease resistance in olive flounder, Paralichthys olivaceus, by probiotic Lactococcus lactis WFLU12 isolated from wild marine fish. Aquaculture 471, 113-120. doi: 10.1016/j.aquaculture.2017.01.008

Nieto, J. M., Devesa, S., Quiroga, I., and Toranzo, A. E. (1995). Pathology of Enterococcus sp. infection in farmed turbot, Scophthalmus maximus L. J. Fish Dis. 18, 21-30. doi: 10.1111/j.1365-2761.1995.tb01262.x

Nikoskelainen, S., Salminen, S., Bylund, G., and Ouwehand, A. C. (2001). Characterization of the properties of human- and dairy-derived probiotics for prevention of infectious diseases in fish. Appl. Environ. Microbiol. 67, 2430-2435, doi: 10.1128/aem.67.6.2430-2435.2001

Nur-Nazifah, M., Sabri, M. Y., and Siti-Zahrah, A. (2014). Development and efficacy of feed-based recombinant vaccine encoding the cell wall surface anchor family protein of Streptococcus agalactiae against streptococcosis in Oreochromis sp. Fish Shellfish Immunol. 37, 193-200. doi: 10.1016/j.fsi.2014.01.011

Nyman, A., Huyben, D., Lundh, T., and Dicksved, J. (2017). Effects of microbe- and mussel-based diets on the gut microbiota in Arctic charr (Salvelinus alpinus). Aquacult Rep. 5, 34-40. doi: 10.1016/j.aqrep.2016.12.003

Ovissipour, M., Abedian Kenari, A., Nazari, R., Motamedzadegan, A., and Rasco, B. (2014). Tuna viscera protein hydrolysate: nutritive and disease resistance properties for Persian sturgeon (Acipenser persicus L.) larvae. Aquacult. Res. 45 591-601. doi: 10.1111/j.1365-2109.212.03257x

Pandiyan, P., Balaraman, D., Thirunavukkarasu, R., George, E. G. T., Subaramaniyan, K., Manikkam, S., et al. (2013). Probiotics in aquaculture. Drug Inven. Today 5, 55-59. doi: 10.1016/j.dit.2013.03.003

Panigrahi, A., Kiron, V., Puangkaew, J., Kobayashi, T., Satoh, S., and Sugita, H. (2005). The viability of probiotic bacteria as a factor influencing the immune response in rainbow trout Oncorhynchus mykiss. Aquaculture 243, 241-254. doi: 10.1016/j/aquaculture.2004.09.032

Parada, J. L., Caron, C. R., Medeiros, A. B. P., and Soccol, C. R. (2007). Bacteriocins from lactic acid bacteria: Purification, properties and use as biopreservatives. Braz. Arch Biol. Technol. 50, 521-542. doi: 10.1590/\$1516-891320070003 00018

Patil, R., Jeyasekaran, G., Shanmugam, S. A., and Shakila, J. R. (2001). Control of bacterial pathogens, associated with fish diseases, by antagonistic marine actinomycetes isolated from marine sediments. Indian J. Mar. Sci. 30, 264-267. Available online: http://nopr.niscair.res.in/handle/123456789/4632

Penberthy, W. T., Shafizadeh, E., and Lin, S. (2002). The zebrafish as a model for human disease. Front. Biosci. 7, D1439-D1453. doi: 10.2741/penber

Peres, H., Lim, C., and Klesius, P. H. (2004). Growth, chemical composition and resistance to Streptococcus iniae challenge of juvenile Nile tilapia (Oreochromis niloticus) fed graded levels of dietary inositol. Aquaculture 235, 423-432. doi: 10.1016/j.aquaculture.2003.09.021

Perez, R. H., Zendo, T., and Sonomoto, K. (2014). Novel bacteriocins from lactic acid bacteria (LAB): Various structures and applications. Microb. Cell Fact. 13:S3. doi: 10.1186/1475-2859-13-S1-S3

Petersen, A., and Dalsgaard, A. (2003). Antimicrobial resistance of intestinal Aeromonas spp. and Enterococcus spp. in fish cultured in 
integrated broiler-fish farms in Thailand. Aquaculture 219, 71-82. doi: 10.1016/S0044-8486(03)00018-8

Piazzon, M. C., Calduch-Giner, J. A., Fouz, B., Estensoro, I., Simó-Mirabet, P., Puyalto, M., et al. (2017). Under control: how a dietary additive can restore the gut microbiome and proteomic profile, and improve disease resilience in a marine teleostean fish fed vegetable diets. Microbiome 5:164. doi: 10.1186/s40168-017-0390-3

Picchietti, S., Fausto, A. M., Randelli, E., Carnevali, O., Taddei, A. R., Buonocore, F., et al. (2009). Early treatment with Lactobacillus delbrueckii strain induces an increase in intestinal T-cells and granulocytes and modulates immune-related genes of larval Dicentrarchus labrax (L.). Fish Shellfish Immunol. 26, 368-376. doi: 10.1016/j.fsi.2008.10.008

Piccolo, G., Bovera, F., Lombardi, P., Mastellone, V., Nizza, S., Di Meo, C., et al. (2015). Effect of Lactobacillus plantarum on growth performance and hematological traits of European sea bass (Dicentrarchus labrax). Aquacult. Inter. 23, 1025-1032. doi: 10.1007/s10499-014-9861-8

Pikuta, E. V., and Hoover, R. B. (2014). "The genus Carnobacterium," in Lactic Acid Bacteria: Biodiversity and Taxonomy, eds E. V. Pikuta and R. B. Hoover (Chichester: John Wiley \& Sons, Ltd.) 109-123. doi: 10.1002/9781118655252.ch10

Pilarski, F., Ferreira De Oliveira, C. A., Darpossolo De Souza, F. P. B., and Zanuzzo, F. S. (2017). Different $\beta$-glucans improve the growth performance and bacterial resistance in Nile tilapia. Fish Shellfish Immunol. 70, 25-29. doi: 10.1016/j.fsi.2017.06.059

Pinpimai, K., Rodkhum, C., Chansue, N., Katagiri, T., Maita, M., and Pirarat, N. (2015). The study on the candidate probiotic properties of encapsulated yeast, Saccharomyces cerevisiae JCM 7255, in Nile Tilapia (Oreochromis niloticus). Res. Vet. Sci. 102, 103-111. doi: 10.1016/j.rvsc.2015.07.021

Pinto, A. L., Fernandes, M., Pinto, C., Albano, H., Castilho, F., Teixeira, P., et al. (2009). Characterization of anti Listeria bacteriocins isolated from shellfish: potential antimicrobials to control non-fermented seafood. Int. J. Food Microbiol. 129, 50-58, doi: 10.1016/j.ijfoodmicro.2008. 11.005

Pirarat, N., Pinpimai, K., Rodkhum, C., Chansue, N., Ooi, E. L., Katagiri, T., et al. (2015). Viability and morphological evaluation of alginate-encapsulated Lactobacillus rhamnosus GG under simulated tilapia gastrointestinal conditions and its effect on growth performance, intestinal morphology and protection against Streptococcus agalactiae. Anim. Feed Sci. Technol. 207, 93-103. doi: 10.1016/j.anifeedsci.2015.03.002

Plumb, J. A., and Hanson, L. A. (2010). “Tilapia bacterial diseases," in Health Maintenance and Principal Microbial Diseases of Cultured Fishes, eds J. A. Plumb and L. A. Hanson (Wiley-Blackwell), 445-463.

Popovic, N. T., Strunjak-Perovic, I., Sauerborn-Klobucar, R., Barisic, J., Jadan, M., Kazazic, S., et al. (2017). The effects of diet supplemented with Lactobacillus rhamnosus on tissue parameters of rainbow trout, Oncorhynchus mykiss (Walbaum). Aquacult. Res. 48, 2388-2401. doi: 10.1111/are. 13074

Pourgholam, M. A., Khara, H., Safari, R., Sadati, M. A. Y., and Aramli, M. S. (2016). Dietary administration of Lactobacillus plantarum enhanced growth performance and innate immune response of Siberian sturgeon, Acipenser baerii. Prob. Antimicrob. Prot. 8, 1-7. doi: 10.1007/s12602-015-9205-7

Prasad, S., Morris, P. C., Hansen, R., Meaden, P. G., and Austin, B. (2005). A novel bacteriocin-like substance (BLIS) from a pathogenic strain of Vibrio harveyi. Microbiology 151, 3051-3058. doi: 10.1099/mic.0.28011-0

Qin, C., Xu, L., Yang, Y., He, S., Dai, Y., Zhao, H., et al. (2014). Comparison of fecundity and offspring immunity in zebrafish fed Lactobacillus rhamnosus CICC 6141 and Lactobacillus casei BL23. Reproduction 147, 53-64. doi: 10.1530/REP-13-0141

Ra, C. H., Kim, Y. J., Park, S. J., Jeong, C. W., Nam, Y. K., Kim, K. H., et al. (2009). Evaluation of optimal culture conditions for recombinant ghost bacteria vaccine production with the antigen of Streptococcus iniae GAPDH. J. Microbiol. Biotechnol. 19, 982-986. doi: 10.4014/jmb.0901.007

Rahman, M., Rahman, M. M., Deb, S. C., Alam, M. S., Alam, M. J., and Islam, M. T. (2017). Molecular identification of multiple antibiotic resistant fish pathogenic Enterococcus faecalis and their control by medicinal herbs. Sci. Rep. 7:3747. doi: 10.1038/s41598-017-03673-1

Rajaram, G., Manivasagan, P., Thilagavathi, B., and Saravanakumar, A. (2010). Purification and characterization of a bacteriocin produced by
Lactobacillus lactis isolated from marine environment. Adv. J. Food Sci. Technol. 2, 138-144.

Rather, I. A., Galope, R., Bajpai, V. K., Lim, J., Paek, W. K., and Park, Y. (2017). Diversity of marine bacteria and their bacteriocins: applications in aquaculture. Rev. Fish Sci. Aquacult. 25, 257-269. doi: 10.1080/23308249.2017.12 82417

Ravelo, C., Magariños, B., López-Romalde, S., Toranzo, A. E., and Romalde, J. L. (2003). Molecular fingerprinting of fish-pathogenic Lactococcus garvieae strains by random amplified polymorphic DNA Analysis. J. Clin. Microbiol. 41, 751-756. doi: 10.1128/JCM.41.2.751-756.2003

Rawls, J. F., Mahowald, M. A., Ley, R. E., and Gordon, J. I. (2006). Reciprocal gut microbiota transplants from zebrafish and mice to germ-free recipients reveal host habitat selection. Cell 127, 423-433. doi: 10.1016/j.cell.2006.08.043

Rawls, J. F., Samuel, B. S., and Gordon, J. I. (2004). Gnotobiotic zebrafish reveal evolutionarily conserved responses to the gut microbiota. Proc. Nat. Acad. Sci. U.S.A. 101, 4596-4601. doi: 10.1073/pnas.0400706101

Ray, A. K., Ghosh, K., and Ringø, E. (2012). Enzyme-producing bacteria isolated from fish gut: a review. Aquacult. Nutr. 18, 465-492. doi: 10.1111/j.1365-2095.2012.00943.x

Reimundo, P., Pignatelli, M., Alcaraz, L. D., D’auria, G., Moya, A., and Guijarro, J. A. (2011). Genome sequence of Lactococcus garvieae UNIUD074, isolated in Italy from a Lactococcosis outbreak. J. Bacteriol. 193, 3684-3685. doi: 10.1128/JB.05210-11

Rengpipat, S., Rueangruklikhit, T., and Piyatiratitivorakul, S. (2014). Evaluations of lactic acid bacteria as probiotics for juvenile seabass Lates calcarifer. Aquacult. Res. 39, 134-143. doi: 10.1111/j.1365-2109.2007.01864.x

Resende, J. A., Silva, V. L., Cesar, D. E., Del'Duca, A., Fontes, C. O., and Diniz, C. G. (2015). Seasonal dynamics of microbial community in an aquaculture system of Nile tilapia (Oreochromis niloticus). Aquacult. Res. 46, 1233-1244. doi: 10.1111 /are.12281.

Rimoldi, S., Terova, G., Ascione, C., Giannico, R., and Brambilla, F. (2018). Next generation sequencing for gut microbiome characterization in rainbow trout (Oncorhynchus mykiss) fed animal by-product meals as an alternative to fish meal protein sources. PLoS ONE 13:e0193652. doi: 10.1371/journal.pone.0193652

Ringø E., Wesmajervi, M. S., Bendiksen, H. R., Berg, A., Olsen, R. E., Johnsen, T., et al. (2001). Identification and characterization of carnobacteria isolated from fish intestine. Syst. Appl. Microbiol. 24, 183-191. doi: 10.1078/0723-2020-00020

Ringø, E. (1993a). Does chromic oxide $\left(\mathrm{Cr}_{2} \mathrm{O}_{3}\right)$ affect faecal lipid and intestinal bacterial flora in Arctic charr, Salvelinus alpinus (L.)? Aquacult. Fish. Manage. 24, 767-776. doi: 10.1111/j.1365-2109.1993.tb00656.x

Ringø, E. (1993b). The effect of chromic oxide $\left(\mathrm{Cr}_{2} \mathrm{O}_{3}\right)$ on aerobic bacterial populations associated with the epithelial mucosa of Arctic charr (Salvelinus alpinus L.). Can. J. Microbiol. 39, 1169-1173. doi: 10.1139/m93-177

Ringø, E. (1994). The effect of chromic oxide $\left(\mathrm{Cr}_{2} \mathrm{O}_{3}\right)$ on faecal lipid and intestinal bacterial flora of sea water reared Arctic charr, Salvelinus alpinus (L.)? Aquacult. Fish. Manage. 25, 341-344. doi: 10.1111/j.1365-2109.1994.tb00697.x

Ringø, E. (2004). "Lactic acid bacteria in fish and fish farming," in Lactic Acid Bacteria, eds S. Salminen, A. Ouwehand, and A. von Wrigth (New York, NY: Marcel Dekker Inc.), 581-610.

Ringø, E. (2008). The ability of carnobacteria isolated from fish intestine to inhibit growth of fish pathogenic bacteria: a screening study. Aquacult Res. 39, 171-180. doi: 10.1111/j.1365-2109.2007.01876.x

Ringø, E., Birkbeck, T. H., Munro, P. D., Vadstein, O., and Hjelmeland, K. (1996). The effect of early exposure to Vibrio pelagius on the aerobic bacterial flora of turbot, Scophthalmus maximus (L.) larvae. J. Appl. Bacteriol. 81, 207-211. doi: 10.1111/j.1365-2672.1996.tb04502.x

Ringø, E., and Gatesoupe, F.-J. (1998). Lactic acid bacteria in fish: a review. Aquaculture 160, 177-203. doi: 10.1016/S0044-8486(97)00299-8

Ringø, E., and Olsen, R. E. (1994). Lipid nutrition in Arctic charr, Salvelinus alpinus (L.): a mini review. Aquacult. Fish. Manag. 25, 823-838. doi: 10.1111/j.1365-2109.1994.tb00746.x

Ringø, E., Olsen, R. E., Gonzales Vecino, J. L., Wadsworth, S., and Song, S. K. (2012a). Use of immunostimulants and nucleotides in aquaculture: a review. J. Mar. Sci. Res. Develop. 2:104. doi: 10.4172/2155-9910.1000104

Ringø, E., Olsen, R. E., Jensen, I., Romero, J., and Lauzon, H. L. (2014). Application of vaccines and dietary supplements in aquaculture: possibilities and challenges. Rev. Fish Biol. Fish. 24, 1005-1032. doi: 10.1007/s11160-014-9361-y 
Ringø, E., Olsen, R. E., Mayhew, T. M., and Myklebust, R. (2003). Electron microscopy of the intestinal microflora of fish. Aquaculture 227, 395-415. doi: 10.1016/j.aquaculture.2003.05.001

Ringø, E., Schillinger, U., and Holzapfel, W. (2005). "Antimicrobial activity of lactic acid bacteria isolated from aquatic animals and the use of lactic acid bacteria in aquaculture," in Biology of Growing Animals, eds W. H. Holzapfel, P. J. Naughton, and S. G. Pierzynowski (Edinburgh, UK: Elsevier), 418-453.

Ringø, E., and Song, S. K. (2016). Application of dietary supplements (synbiotics and probiotics in combination with plant products and $\beta$-glucans) in aquaculture: Aquacult. Nutr. 22, 4-24. doi: 10.1111/anu12349.

Ringø, E., Zhou, Z., Gonzalez Vecino, J. L., Wadsworth, S., Romero, J., Krogdahl, $\AA$., et al. (2016). Effects of dietary components on the gut microbiota of aquatic animals: a never-ending story? Aquacult. Nutr. 22, 219-282. doi: $10.1111 /$ anu12346

Ringø, E., Zhou, Z., Olsen, R. E., and Song, S. K. (2012b). Use of chitin and krill in aquaculture - effect on gut microbiota and the immune system: a review. Aquacult. Nutr. 18, 117-131. doi: 10.1111/j.1365-2095.2011.00919.x

Rodriguez-Estrada, U., Satoh, S., Haga, Y., Fushimi, H., and Sweetman, J. (2013). Effects of inactivated Enterococcus faecalis and mannan oligosaccharide and their combination of growth, immunity, and disease protection in rainbow trout. N. Am. J. Aquacult. 75, 416-428. doi: 10.1080/15222055.2013.799620

Román, L., Padilla, D., Acosta, F., Sorroza, L., Fátima, E., Déniz, S., et al. (2015). The effect of probiotic Enterococcus gallinarum L-1 on the innate immune parameters of outstanding species to marine aquaculture. J. Appl. Anim. Res. 43, 177-183. doi: 10.1080/09712119.2014.928635

Romero, J., Feijoo, C. G., and Navarrete, P. (2012). “Antibiotics in aquaculture use, abuse and alternatives," in Health and Environment in Aquaculture, ed E. Carvalho (In-Tech), 159-198.

Round, J. L., and Mazmanian, S. K. (2009). The gut microbiota shapes intestinal immune responses during health and disease. Nat. Rev. Immunol. 9, 313-323. doi: $10.1038 /$ nri2614

Rudi, K., Angell, I. L., Pope, P. B., Vik, J. O., Sandve, S. R., and Snipen, L.-G. (2018). Stable core gut microbiota across the freshwater-tosaltwater transition for farmed Atlantic salmon. Appl. Environ. Microbiol. 84, e01974-17. doi: 10.1128/AEM.01974-17

Saeidi Asl, M. R., Adel, M., Caipang, C. M. A., and Dawood, M. A. O. (2017). Immunological responses and disease resistance of rainbow trout (Oncorhynchus mykiss) juveniles following dietary administration of stinging nettle (Urtica dioica). Fish Shellfish Immunol. 71, 230-238. doi: 10.1016/j.fsi.2017.10.016

Safari, R., Adel, M., Lazado, C. C., Caipang, C. M. A., and Dadar, M. (2016). Host-derived probiotics Enterococcus casseliflavus improves resistance against Streptococcus iniae infection in rainbow trout (Oncorhynchus mykiss) via immunomodulation. Fish Shellfish Immunol. 52, 198-205. doi: $10.1016 /$ j.fsi.2016.03.020.

Safari, R., Hoseinifar, S. H., Nejadmoghadam, S., and Khalili, M. (2017). Apple cider vinegar boosted immunomodulatory and health promoting effects of Lactobacillus casei in common carp (Cyprinus carpio). Fish Shellfish Immunol. 67, 441-448. doi: 10.1016/j.fsi.2017.06.017

Sahoo, T. K., Jena, P. K., Patel, A. K., and Seshadri, S. (2016). Bacteriocins and their applications for the treatment of bacterial diseases in aquaculture: a review. Aquacult. Res. 47, 1013-1027. doi: 10.1111/are.12556

Salas-Leiva, J., Opazo, R., Remond, C., Uribe, E., Velez, A., and Romero, J. (2017). Characterization of the intestinal microbiota of wild-caught and farmed fine flounder (Paralichthys adspersus). Lat. Am. J. Aquat. Res. 42, 370-378. doi: 10.3856/vol45-issue2-fulltext-12

Salinas, I., Díaz-Rosales, P., Cuesta, A., Meseguer, J., Chabrillón, M., Morinigo, M. A., et al. (2006). Effect of heat-inactivated fish and non-fish derived probiotics on the innate immune parameters of a teleost fish (Sparus aurata L.). Vet. Immunol. Immunopatol. 111, 279-286. doi: 10.1016/j.vetimm.2006.01.020

Salma, W., Zhou, Z., Wang, W., Askarian, F., Kousha, A., Ebrahimi, M. T., et al. (2011). Histological and bacteriological changes in intestine of beluga (Huso huso) following ex vivo exposure to bacterial strains. Aquaculture 314, 24-33. doi: 10.1016/j.aquaculture.2011.01.047

Sarika, A. R., Lipton, A. P., Aishwarya, M. S., and Dhivya, R. S. (2012). Isolation of a bacteriocin-producing Lactococcus lactis and application of its bacteriocin to manage spoilage bacteria in high-value marine fish under different storage temperatures. Appl. Biochem. Biotechnol. 167, 1280-1289. doi: 10.1007/s12010-012-9701-0

Sarika, A. R., Lipton, A. P., Aishwarya, M. S., and Rachana mol, R. S. (2017). Lactic acid bacteria from marine fish: antimicrobial resistance and production of bacteriocin effective against L. monocytogenes in situ. J. Food: Microbiol. Safety Hyg. 3:1. doi: 10.4172/2476-2059.1000128

Satish Kumar, R., Kanmani, P., Yuvaraj, N., Paari, K. A., Pattukumar, V., and Arul, V. (2011). Purification and characterization of enterocin MC13 produced by a potential aquaculture probiont Enterococcus faecium MC13 isolated from the gut of Mugil cephalus. Can. J. Microbiol. 57, 993-1001. doi: 10.1139/w11-092

Schillinger, U., and Lücke, F. K. (1989). Antibacterial activity of Lactobacillus sake isolated from meat. Appl. Environ. Microbiol. 55, 1901-1906.

Schleifer, K. H., and Kilpper-Bälz, R. (1984). Transfer of Streptococcus faecalis and Streptococcus faecium to the Genus Enterococcus norn. rev. as Enterococcus faecalis comb. nov. and Enterococcus faecium comb. nov. Int. J. Syst. Bacteriol. 34, 31-34. doi: 10.1099/00207713-34-1-31

Schleifer, K. H., Kraus, J., Dvorak, C., Kilpper-Balz, R., Collins, M. D., and Fischer, W. (1985). Transfer of Streptococcus lactis and related streptococci to the genus Lactococcus gen nov. Syst. Appl. Microbiol. 6, 183-195. doi: 10.1016/S0723-2020(85)80052-7

Serra, C. R., Magalháes Júnior, F., Couto, A. M., Oliva-Teles, A., and Enes, P. (2018). Gut microbiota and gut morphology of gilthead sea bream (Sparus aurata) juveniles are not affected by chromic oxide as digestibility marker. Aquacult. Res. 49, 1347-1356. doi: 10.1111/are.13596

Shahid, M., Hussain, B., Riaz, D., Khurshid, M., Ismail, M., and Tariq, M. (2017). Identification and partial characterization of potential probiotic lactic acid bacteria in freshwater Labeo rohita and Cirrhinus mrigala. Aquacult. Res. 48, 1688-1698. doi: 10.1111/are.13006

Shih-Chu, C., Yu-De, L., Li-Ling, L., and Pei-Chi, W. (2001). Lactococcus garvieae infection in the giant freshwater prawn Macrobranchium rosenbergii confirmed by polymerase chain reaction and $16 \mathrm{~S}$ rDNA sequencing. Dis. Aquat. Org. 45, 45-52. doi: 10.3354/dao045045

Shoemaker, C. A., Klesius, P. H., and Evans, J. J. (2001). Prevalence of Streptococcus iniae in tilapia, hybrid striped bass, and channel catfish on commercial fish farms in the United States. Am. J. Vet. Res. 62, 174-177. doi: 10.2460/ajvr.2001.62.174

Silva, C. C. G., Silva, S. P. M., and Riberio, S. C. (2018). Application of bacteriocins and protective cultures in dairy food preservation. Front. Microbiol. 9:594. doi: 10.3389/fmicb.2018.00594

Singh, R., Sivasubramani, K., Jayalakshmi, S., Satheesh Kumar, S., and Selvi, C. (2013). Isolation and production of bacteriocin by marine Lactobacillus fermentum SBS001. Int. J. Curr. Microbiol. Appl. Sci. 2, 67-73.

Soltani, M., Abdy, E., Alishahi, M., Mirghaed, A. T., and Hosseini-Shekarabi, P. (2017b). Growth performance, immune-physiological variables and disease resistance of common carp (Cyprinus carpio) orally subjected to different concentrations of Lactobacillus plantarum. Aquacult. Inter. 25, 1913-1933. doi: 10.1007/s10499-017-0164-8

Soltani, M., Ghodratnama, M., Ebrahimzadeh-Mosavi, H. A., Nikbakht-Brujeni, G., Mohamadian, S., and Ghasemian, M. (2014). Shirazi thyme (Zataria multiflora Boiss) and Rosemary (Rosmarinus officinalis) essential oils repress expression of sagA, a streptolysin S-related gene in Streptococcus iniae. Aquaculture 430, 248-252. doi: 10.1016/j.aquaculture.2014.04.012

Soltani, M., Mohamadian, S., Rouholahi, S., Soltani, E., and Rezvani, S. (2015). Shirazi thyme (Zataria multiflora) essential oil suppresses the expression of PavA and Hly genes in Lactococcus garvieae, the causative agent of lactococcosis in farmed fish. Aquaculture 442, 74-77. doi: 10.1016/j.aquaculture.2015.03.001

Soltani, M., Pakzad, K., Taheri-Mirghaed, A., Mirzargar, S., Shekarabi, S. P. H., Yosefi, P., et al. (2017a). Dietary application of the probiotic Lactobacillus plantarum 426951 enhances immune status and growth of rainbow trout (Oncorhynchus mykiss) vaccinated against Yersinia ruckeri. Probiotics Antimicrob. Proteins. doi: 10.1007/s12602-017-9376-5

Srionnual, S., Yanagida, F., Lin, L. H., Hsiao, K. N., and Chen, Y. S. (2007). Weissellicin 110, a newly discovered bacteriocin from Weissella cibaria 110, isolated from plaa-som, a fermented fish product from Thailand. Appl. Environ. Microbiol. 73, 2247-2250. doi: 10.1128/AEM.02484-06

Srisapoome, P., and Areechon, N. (2017). Efficacy of viable Bacillus pumilus isolated from farmed fish on immune responses and increased disease 
resistance in Nile tilapia (Oreochromis niloticus): laboratory and onfarm trials. Fish Shellfish Immunol. 67, 199-210. doi: 10.1016/j.fsi.2017. 06.018

Standen, B. T., Peggs, D. L., Rawling, M. D., Foey, A., Davies, S. J., Santos, G. A., et al. (2016). Dietary administration of a commercial mixedspecies probiotic improves growyh performance and modulates the intestinal immunity of tilapia, Ocerchromis niloticus. Fish Shellfish Immuniol. 49, 427-435. doi: 10.1016/j.fsi.2015.11.037

Standen, B. T., Rodiles, A., Peggs, D. L., Davies, S. J., Santos, G. A., and Merrifield, D. L. (2015). Modulation of the intestinal microbiota and morphology of tilapia, Ocerchromis niloticus, following the application of a multi-species probiotic. Appl. Microbiol. Biotechnol. 99, 84013-88417. doi: 10.1007/s00253-015-6702-2

Starliper, C. E., Shotts, E. B., and Brown, J. (1992). Isolation of Carnobacterium piscicola and an unidentified Gram-positive bacillus from sexually mature and post-spawning rainbow trout Oncorhynchus mykiss. Dis. Aquat. Org. 13, 181-187. doi: 10.3354/dao013181

Stoffregen, D. A., Backman, S. C., Perham, R. E., Bowser, P. R., and Babish, J. G. (1996). Initial disease report of Streptococcus iniae infection in hybrid striped (Sunshine) bass and successful therapeutic intervention with the fluoroquinolone antibacterial enrofloxacin. J. World Aquacult. Soc. 27, 420-434. doi: 10.1111/j.1749-7345.1996.tb00626.x

Strøm, E. (1988). Melkesyrebakterier i Fisketarm: Isolasjon, Karakterisering og Egenskaper [in Norwegian]. MSc thesis, The Norwegian College of Fishery Science, University of Tromsø, Norway.

Sugita, H., and Ito, Y. (2006). Identification of intestinal bacteria from Japanese flounder (Paralichthys olivaceus) and their ability to digest chitin. Lett. Appl. Microbiol. 43, 336-342. doi: 10.1111/j.1472-765X.2006. $\mathrm{x}$

Sugita, H., Ohta, K., Kuruma, A., and Sagesaka, T. (2007). An antibacterial effect of Lactococcus lactis isolated from the intestinal tract of the Amur catfish, Silurus asotus Linnaeus. Aquacult. Res. 38, 1002-1004. doi: 10.1111/j.1365-2109.2007.01765.x

Šušković, J., Kos, B., Beganović, J., Leboš Pavunc, A., Habjanič, K., and Matošić, S. (2010). Antimicrobial activity - the most important property of probiotic and starter lactic acid bacteria. Food Technol. Biotechnol. 48, 296-307.

Tahmasebi-Kohyani, A., Keyvanshokooh, S., Nematollahi, A., Mahmoudi, N., and Pasha-Zanoosi, H. (2011). Dietary administration of nucleotides to enhance growth, humoral immune responses, and disease resistance of the rainbow trout (Oncorhynchus mykiss) fingerlings. Fish Shellfish Immunol. 30, 189-193. doi: $10.1016 /$ j.fsi.2010.10.005

Tarnecki, A. M., Burgos, F. A., Ray, C. L., and Arias, C. R. (2017). Fish intestinal microbiome: diversity and symbiosis unraveled by metagenomics. J. Appl. Microbiol. 123, 2-17. doi: 10.1111/jam.13415

Tarnecki, A. M., and Rhody, N. R. (2017). Microbiota of common snook Centropomus undecimalis larvae exhibiting high mortality. Aquacult. Res. 48, 5693-5698. doi: 10.1111/are.13377

Todorov, S. D. (2009). Bacteriocins from Lactobacillus plantarum - production, genetic organization and mode of action. A review. Braz. J. Microbiol. 40, 209-221. doi: 10.1590/S1517-83822009000200001

Toranzo, A. E., Novoa, B., Baya, A. M., Hetrick, F. M., Barja, J. L., and Figueras, A. (1993a). Histopathology of rainbow trout, Oncorhynchus mykiss (Walbaum), and striped bass, Morone saxatilis (Walbaum), experimentally infected with Carnobacterium piscicola. J. Fish Dis. 16, 261-267. doi: 10.1111/j.1365-2761.1993.tb01256.x

Toranzo, A. E., Romalde, J. L., Nunez, S., Figueras, A., and Barja, J. L. (1993b). An epizootic in farmed, market-size rainbow trout in Spain caused by a strain of Carnobacterium piscicola of unusual virulence. Dis. Aquat. Org. 17, 87-99. doi: $10.3354 /$ dao017087

Torrecillas, S., Mompel, D., Caballero, M. J., Monteri, D., Merrifield, D., Rodiles, A., et al. (2017). Effect of fishmeal and fish oil replacement by vegetable meals and oils on gut health of European sea bass (Dicentrarchus labrax). Aquaculture 468, 386-398. doi: 10.1016/j.aquaculture.2016.11.005

Tran, N. T., Wang, G.-T., and Wu, S.-G. (2017). A review of intestinal microbes in grass carp Ctenopharyngodon idellua (Valenciennes). Aquacult Res. 48, 3287-3397. doi: 10.111/are.13367

Turner, M. D., Nedjai, B., Hurst, T., and Pennington, D. J. (2014). Cytokines and chemokines: at the crossroads of cell signaling and inflammatory disease. Biochim. Biophys. Acta 1843, 2563-2582. doi: 10.1016/j.bbamcr.2014.05.014
Tytgat, H. L. P., Douillard, F. P., Reuanen, J., Rasinkangas, P., Hendrickx, A. P. A., Laine, P. K., et al. (2016). Lactobacillus rhamnosus GG outcompete Enterococcus faecium via mucus-binding pili: Evidence for a novel and heterospecific probiotic mechanism. Appl. Environ. Microbiol. 82, 5756-5762. doi: 10.1128/AEM.01243-16

Vílchez, M. C., Santangeli, S., Maradonna, F., Gioacchini, G., Verdenelli, C., Gallego, V., et al. (2015). Effect of the probiotic Lactobacillus rhamnosus on the expression of genes involved in European eel spermatogenesis. Theriogenology 84, 1321-1331. doi: 10.1016/j.theriogenology.2015.07.011

Vadanasundari, V., Rangabhashiyam, S., Sankaran, K., and Hemavathy, R. V. (2013). Production, purification and characterization of bacteriocins by Lactobacillus lactis from marine environment. Int. J. Adv. Innov. Res. 1, 340-346.

Valcarce, D. G., Pardo, M. Á., Riesco, M. F., Cruz, Z., and Robles, V. (2015). Effect of diet supplementation with a commercial probiotic containing Pediococcus acidilactici (Lindner, 1887) on the expression of five quality markers in zebrafish (Danio rerio (Hamilton, 1822)) testis. J. Appl. Ichthyol. 31, 18-21. doi: $10.1111 /$ jai.12731

Valenzuela, A. S., Benomar, N., Abriouel, H., Canamero, M. M., and Galvez, A. (2010). Isolation and identification of Enterococcus faecium from seafoods: antimicrobial resistance and production of bacteriocin-like substances. Food Microbiol. 27, 955-961. doi: 10.1016/j.fm.2010.05.033

Van Doan, H., Doolgindachbaporn, S., and Suksri, A. (2016b). Effect of Lactobacillus plantarum and Jerusalem artichoke (Helianthus tuberosus) on growth performance, immunity and disease resistance of Pangasius catfish (Pangasius bocourti, Sauvage 1880). Aquacult. Nutr. 22, 444-456. doi: 10.1111/anu.12263

Van Doan, H., Doolgindachbaporn, S., and Suksri, A. (2016c). Effects of Eryngii mushroom (Pleurotus eryngii) and Lactobacillus plantarum on growth performance, immunity and disease resistance of Pangasius catfish (Pangasius bocourti, Sauvage 1880). Fish Physiol. Biochem. 45, 1427-1440. doi: 10.1007/s10695-016-0230-6

Van Doan, H., Doolgindachbapron, S., and Suksri, A. (2014). Effects of low molecular weight agar and Lactobacillus plantarum on growth performance, immunity, and disease resistance of basa fish (Pangasius bocourti, Sauvage 1880). Fish Shellfish Immunol. 41, 340-345. doi: 10.1016/j.fsi.2014.09.015

Van Doan, H., Hoseinifar, S. H., Dawood, M. A. O., Chitmanat, C., and Tayyamath, K. (2017a). Effects of Cordyceps militaris spent mushroom substrate and Lactobacillus plantarum on mucosal, serum immunology and growth performance of Nile tilapia (Oreochromis niloticus). Fish Shellfish Immunol. 70, 87-94. doi: 10.1016/j.fsi.2017.09.002

Van Doan, H., Hoseinifar, S. H., Tapingkae, W., and Khamtavee, P. (2017b). The effects of dietary kefir and low molecular weight sodium alginate on serum immune parameters, resistance against Streptococcus agalactiae and growth performance in Nile tilapia (Oreochromis niloticus). Fish Shellfish Immunol. 62, 139-146. doi: 10.1016/j.fsi.2017.01.014

Van Doan, H., Hoseinifar, S. H., Tapingkae, W., Tongsiri, S., and Khamtavee, P. (2016a). Combined administration of low molecular weight sodium alginate boosted immunomodulatory, disease resistance and growth enhancing effects of Lactobacillus plantarum in Nile tilapia (Oreochromis niloticus). Fish Shellfish Immunol. 58, 678-685. doi: 10.1016/j.fsi.2016.10.013

Vendrell, D., Balcázar, J. L., Ruiz-Zarzuela, I., de Blas, I., Gironès, O. and Mùzquiz, J. L. (2006). Lactococcus garvieae in fish: a review. Comp. Immunol. Microbiol. Inf. Dis. 29, 177-198. doi: 10.1016/j.cimid.2006. 06.003

Vendrell, D., Balcázar, J. L., Ruiz-Zarzuela, I., De Blas, I., Gironés, O., and Múzquiz, J. L. (2007). Safety and efficacy of an inactivated vaccine against Lactococcus garvieae in rainbow trout (Oncorhynchus mykiss). Prevent Vet Med. 80, 222-229. doi: 10.1016/j.prevetmed.2007.02.008

Ventura, M., O’Flaherty, S., Claesson, M. J., Turroni, F., Klaenhammer, T. R., van Sinderen, D., et al. (2009). Genome-scale analyses of health-promoting bacteria: probiogenomics. Nat. Rev. Microbiol. 7, 61-77. doi: 10.1038/ nrmicro2047

Verschuere, L., Rombaut, G., Sorgeloos, P., and Verstraete, W. (2000). Probiotic bacteria as biocontrol agents in aquaculture. Microbiol. Mol. Biol. Rev. 64, 655-671. doi: 10.1128/MMBR.64.4.655-671.2000

Villamil, L., Reyes, C., and Martínez-Silva, M. A. (2014). In vivo and in vitro assessment of Lactobacillus acidophilus as probiotic for tilapia (Oreochromis 
niloticus, Perciformes: Cichlidae) culture improvement. Aquacult. Res. 45, 1116-1125. doi: 10.1111/are.12051

Walter, J. (2008). Ecological role of lactobacilli in the gastrointestinal tract: Implications for fundamental and biomedical research. Appl. Environ. Microbiol. 74, 4985-4996. doi: 10.1128/AEM.00753-08

Wang, A.n R., Ran, C., Ringø, E., and Zhou, Z. (2018). Progress in fish gastrointestinal microbiota research. Rev. Aquacult. doi: 10.1111/raq.12191

Wang, J., Zou, L. L., and Li, A. X. (2014). Construction of a Streptococcus iniae sortase A mutant and evaluation of its potential as an attenuated modified live vaccine in Nile tilapia (Oreochromis niloticus). Fish Shellfish Immunol. 40, 392-398. doi: 10.1016/j.fsi.2014.07.028

Wang, T., and Secombes, C. J. (2013). The cytokine networks of adaptive immunity in fish. Fish Shellfish Immunol. 35, 1703-1718. doi: 10.1016/j.fsi.2013.08.030

Wang, Y. B., Tian, Z. Q., Yao, J. T., and Li, W. F. (2008). Effect of probiotics, Enteroccus faecium, on tilapia (Oreochromis niloticus) growth performance and immune response. Aquaculture 277, 203-207. doi: 10.1016/j.aquaculture.2008.03.007

Whyte, S. K. (2007). The innate immune response of finfish - a review of current knowledge. Fish Shellfish Immunol. 23, 1127-1151. doi: 10.1016/j.fsi.2007.06.005

Wu, Y.-R., Gong, Q.-F., Fang, H., Liang, W.-W., Chen, M., and He, R.-J. (2013). Effect of Sophora flavescens on non-specific immune response of tilapia (GIFT Oreochromis niloticus) and disease resistance against Streptococcus agalactiae. Fish Shellfish Immunol. 34, 220-227. doi: 10.1016/j.fsi.2012.10.020

Wu, Z. B., Gatesoupe, F. J., Li, T. T., Wang, X. H., Zhang, Q. Q., Feng, D. Y., et al. (2018). Significant improvement of intestinal microbiota of gibel carp (Carassius auratus gebelio) after traditional Chinese medicine feeding. J. Appl. Microbiol. 124, 829-841. doi: 10.1111/jam.13674

Yamashita, M., Pereira, S., Cardoso, L., Araujo, A., Oda, C., Schmidt, É., et al. (2017). Probiotic dietary supplementation in Nile tilapia as prophylaxis against streptococcosis. Aquacult. Nutr. 23, 1235-1243. doi: 10.1111/anu.12498

Yan, Y. Y., Xia, H. Q., Yang, H. L., Hoseinifar, S. H., and Sun, Y. Z. (2016). Effects of dietary live or heat-inactivated autochthonous Bacillus pumilus SE5 on growth performance, immune responses and immune gene expression in grouper Epinephelus coioides. Aquacult. Nutr. 22, 698-707. doi: 10.1111/anu.12297

Yang, H.-T., Zou, S.-S., Zhai, L.-J., Wang, Y., Zhang, F.-M., An, L.-G., et al. (2017). Pathogen invasion changes the intestinal microbiota composition and induces innate immune responses in the zebrafish intestine. Fish Shellfish Immunol. 71, 35-42. doi: 10.1016/j.fsi.2017.09.075

Yang, P., Hu, H., Liu, Y., Li, Y., Ai, Q., Xu, W., et al. (2018). Dietary stachyose altered the intestinal microbiota profile and improved the intestinal mucosal barrier function of juvenile turbot, Scophthalmus maximus L. Aquaculture 486, 98-106. doi: 10.1016/j.aquaculture.2017.12.014

Yang, W., and Li, A. (2009). Isolation and characterization of Streptococcus dysgalactiae from diseased Acipenser schrenckii. Aquaculture 294, 14-17. doi: 10.1016/j.aquaculture.2009.05.018

Yi, T., Li, Y.-W., Liu, L., Xiao, X.-X., and Li, A.-X. (2014). Protection of Nile tilapia (Oreochromis niloticus L.) against Streptococcus agalactiae following immunization with recombinant FbsA and $\alpha$-enolase. Aquaculture 428-429, 35-40. doi: 10.1016/j.aquaculture.2014.02.027

Yin, L. J., Wu, C. W., and Jiang, S. T. (2007). Biopreservative effect of pediocin ACCEL on refrigerated seafood. Fish Sci. 73, 907-912. doi: 10.1111/j.1444-2906.2007.01413.x

Yu, L., Zhai, Q., Zhu, J., Zhang, C., Li, T., Liu, X., et al. (2017). Dietary Lactobacillus plantarum supplementation enhances growth performance and alleviates aluminum toxicity in tilapia. Ecotoxicol Environ. Saf. 143, 307-314. doi: 10.1016/j.ecoenv.2017.05.023
Yuasa, K., Kitancharoen, N., Kataoka, Y., and Al-Murbaty, F. A. (1999). Streptococcus iniae, the causative agent of mass mortality in rabbitfish Siganus canaliculatus in Bahrain. J. Aquat. Anim. Health 11, 87-93. doi: 10.1577/15488667(1999)011<0087:SITCAO > 2.0.CO;2

Zacharof, M. P., and Lovitt, R. W. (2012). Bacteriocins produced by lactic acid bacteria: a review article. APCBEE Proc. 2, 50-56. doi: 10.1016/j.apcbee.2012.06.010

Zai, A. S., Ahmad, S., and Rasool, S. A. (2009). Bacteriocin production by indigenous marine catfish associated Vibrio spp. Pakistan J. Pharma. Sci. 22, 162-167. doi: 10.1007/s11274-015-1903-5

Zarkasi, K. Z., Taylor, R., Abell, G. C. J., Tamplin, M. L., Glencross, B. D., and Bowman, J. P. (2016). Atlantic salmon (Salmo salar L.) gastrointestinal microbial community dynamics in relation to digesta properties and diet. Microb. Ecol. 71, 589-603. doi: 10.1007/s00248-015-0728-y

Zhai, Q. X., Yu, L., Li, T., Zhu, J., Zhang, C., Zhao, J., et al. (2017). Effect of dietary probiotic supplementation on intestinal microbiota and physiological conditions of Nile tilapia (Oreochromis niloticus) under waterborne cadmium exposure. Antonie Van Leeuwenhoek 110, 501-513. doi: 10.1007/s10482-016-0819-x

Zhang, C.-N., Zhang, J.-L., Guan, W.-C., Zhang, X.-F., Guan, S.-H., Zeng, Q.-H., et al. (2017). Effects of Lactobacillus delbrueckii on immune response, disease resistance against Aeromonas hydrophila, antioxidant capability and growth performance of Cyprinus carpio var Huanghe. Fish Shellfish Immunol. 68, 84-91. doi: 10.1016/j.fsi.2017. 07.012

Zhang, Z., Yu, A., Lan, J., Zhang, H., Hu, M., Cheng, J., et al. (2017). GapA, a potential vaccine candidate antigen against Streptococcus agalactiae in Nile tilapia (Oreochromis niloticus). Fish Shellfish Immunol. 63, 255-260. doi: 10.1016/j.fsi.2017.02.019

Zhou, L., Limbu, S. M., Qiao, F., Du, F.-Q., and Zhang, M. (2018). Influence of long-term feeding antibiotics on the gut health of zebrafish. Zebrafish. doi: 10.1089/zeb.2017.1526. [Epub ahead of print].

Zhou, M., Liang, R., Mo, J., Yang, S., Gu, N., Wu, Z., et al. (2018). Effects of brewer's yeast hydrolysate on the growth performance and the intestinal bacterial diversity of largemouth bass (Micropterus salmoides). Aquaculture 484, 139-144. doi: 10.1016/j.aquaculture.2017. 11.006

Zhou, Z., Ringø, E., Olsen, R. E., and Song, S. K. (2018). Dietary effects of soybean products on gut microbiota and immunity of aquatic animals: a review. Aquacult. Nutr. 24, 644-665. doi: 10.1111/anu 12532

Zhu, L., Yang, Q., Huang, L., Wang, K., Wang, X., Chen, D., et al. (2017). Effectivity of oral recombinant DNA vaccine against Streptococcus agalactiae in Nile tilapia. Dev. Comp. Immunol. 77, 77-87. doi: 10.1016/j.dci.2017. 07.024

Conflict of Interest Statement: The authors declare that the research was conducted in the absence of any commercial or financial relationships that could be construed as a potential conflict of interest.

Copyright (c) 2018 Ringø, Hoseinifar, Ghosh, Doan, Beck and Song. This is an openaccess article distributed under the terms of the Creative Commons Attribution License (CC BY). The use, distribution or reproduction in other forums is permitted, provided the original author(s) and the copyright owner(s) are credited and that the original publication in this journal is cited, in accordance with accepted academic practice. No use, distribution or reproduction is permitted which does not comply with these terms. 